\title{
Aspects of term breech deliveries in current medical practice
}

Citation for published version (APA):

Molkenboer, J. F. M. (2007). Aspects of term breech deliveries in current medical practice. [Doctoral Thesis, Maastricht University]. Datawyse / Universitaire Pers Maastricht.

https://doi.org/10.26481/dis.20071211jm

Document status and date:

Published: 01/01/2007

DOI:

10.26481/dis.20071211jm

Document Version:

Publisher's PDF, also known as Version of record

\section{Please check the document version of this publication:}

- A submitted manuscript is the version of the article upon submission and before peer-review. There can be important differences between the submitted version and the official published version of record.

People interested in the research are advised to contact the author for the final version of the publication, or visit the DOI to the publisher's website.

- The final author version and the galley proof are versions of the publication after peer review.

- The final published version features the final layout of the paper including the volume, issue and page numbers.

Link to publication

\footnotetext{
General rights rights.

- You may freely distribute the URL identifying the publication in the public portal. please follow below link for the End User Agreement:

www.umlib.nl/taverne-license

Take down policy

If you believe that this document breaches copyright please contact us at:

repository@maastrichtuniversity.nl

providing details and we will investigate your claim.
}

Copyright and moral rights for the publications made accessible in the public portal are retained by the authors and/or other copyright owners and it is a condition of accessing publications that users recognise and abide by the legal requirements associated with these

- Users may download and print one copy of any publication from the public portal for the purpose of private study or research.

- You may not further distribute the material or use it for any profit-making activity or commercial gain

If the publication is distributed under the terms of Article $25 \mathrm{fa}$ of the Dutch Copyright Act, indicated by the "Taverne" license above, 
Aspects of term breech deliveries in current medical practice 
Cover: Monumento de los danzantes, Monte Albán, Oaxaca, Mexico

The monument shows carvings of naked human figures in strange positions, originally thought to be dancers. Their real significance is unknown, but they are now believed to depict various medical deformities, like a woman in breech delivery, as illustrated on the cover of this thesis. The carvings were created by the Olmec and date back to the origin of the city, $2000 \mathrm{BC}$. In the following centuries, the city was inhabited by the Zapotec, Mixtec, Aztec and finally the Spanish, who gave the city it's current name, Monte Albán.

(photo by J. Molkenboer)

ISBN 978-90-5278-655-1

Universitaire Pers Maastricht

(C) Copyright JFM Molkenboer, Maastricht 2007.

All rights reserved. No part of this thesis may be reproduced or transmitted in any form or by any means, without permission of the copyright owner.

Financial support for publication of this thesis has kindly been provided by:

Ferring BV, Organon Nederland BV, Solvay Pharma BV, Bayer Shering Pharma, Johnson \& Johnson, Covidien, Stöpler BV. 


\title{
Aspects of term breech deliveries in current medical practice
}

\author{
PROEFSCHRIFT \\ ter verkrijging van de graad van doctor \\ aan de Universiteit Maastricht, \\ op gezag van de Rector Magnificus, \\ Prof. mr. G.P.M.F. Mols, \\ volgens het besluit van het College van Decanen, \\ in het openbaar te verdedigen \\ op dinsdag 11 december 2007 om 16.00 uur \\ door \\ Jan Frans Marie Molkenboer \\ Geboren 5 mei 1971 te Sittard
}

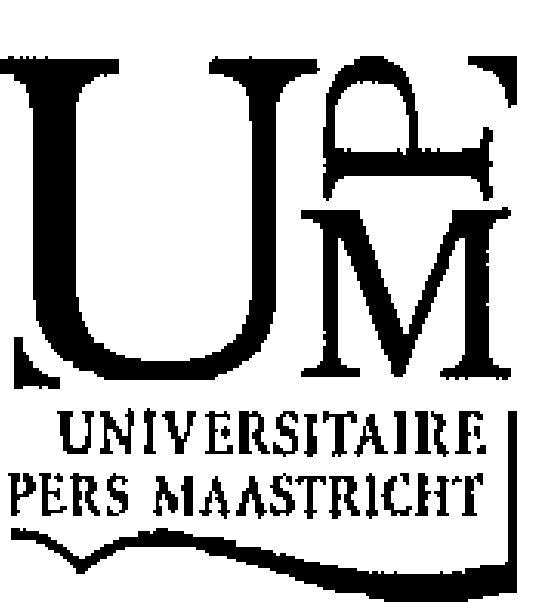




\section{Promotor}

Prof. dr. J.G. Nijhuis

\section{Copromotores}

Dr. F.J.M.E. Roumen (Atrium Medisch Centrum Parkstad, Heerlen)

Dr. L.J.M. Smits

\section{Beoordelingscommissie}

Prof. dr. L.J.I. Zimmermann (voorzitter)

Dr. S.E. Buitendijk (TNO Kwaliteit van Leven, Leiden)

Prof. dr. G.H.A. Visser (Universitair Medisch Centrum, Utrecht)

Prof. dr. G.M.W.R. de Wert 


\section{TABLE OF CONTENTS}

$\begin{array}{lll}\text { Chapter } 1 & \text { Introduction and aim of this thesis } & 7\end{array}$

Chapter 2 Recent trends in breech delivery in the Netherlands 15 BJOG 2003;110:948-51

Chapter 3 Moderate neonatal morbidity after vaginal term breech delivery J Matern Fetal Neonatal Med 2004;16:357-61

Chapter 4 Birth weight and neurodevelopmental outcome of children at 2 years of age after planned vaginal delivery for breech presentation at term

Am J Obstet Gynecol 2006;194:624-9

Chapter 5 Maternal health outcomes two years after term breech delivery J Matern Fetal Neonatal Med 2007;20:319-24

Chapter 6 Mother's' views of their childbirth experience two years after term breech delivery

J Psychosom Obstet Gynaecol 2007; Jul 19:1-6 [Epub ahead of print]

Chapter 7 Conservative management in breech deliveries leads to similar results compared with cephalic deliveries J Matern Fetal Neonatal Med 2007;20:599-603

Chapter 8 How to counsel a pregnant woman with a near term foetus in breech position?

Adapted from: Reproductieve geneeskunde, gynaecologie en obstetrie anno 2007. p 500-5

Chapter 9 Epilogue

Chapter 10 Summary

Chapter 11 Nederlandstalige samenvatting

Dankwoord

Curriculum Vitae

List of publications 
Introduction and aim of this thesis 


\section{Breech presentation}

Breech presentation at term occurs in $3-4 \%$ of pregnancies. ${ }^{.}$The proportion of breech positions is higher at low gestational age compared to term pregnancy. The prevalence of breech position is about $30 \%$ at a gestational age of 24 to 26 weeks. There is a continuous decline towards term to approximately $20 \%$ at 30 weeks, $10 \%$ at 35 weeks and $2 \%$ at 40 weeks, respectively. Spontaneous version is less likely in pregnancies with extended foetal legs, low birth weight, short umbilical cord and in primiparity. ${ }^{2}$ Due to its frequent occurrence all obstetricians will have to deal with this type of presentation and the possible obstetrical problems during breech delivery.

\section{Type of breech presentation}

There are three main categories of breech presentation: frank breech, complete breech and incomplete breech. The frank or extended breech is the most common type of breech presentation at term and occurs in about $75 \%$ of term breech cases. ${ }^{3}$ Here, both thighs of the foetus are flexed and both lower legs are extended at the knees. In the complete or flexed breech both thighs are flexed and both lower extremities are llexed at the knees, whereas in the incomplete breech both thighs of the foetus are llexed, one lower leg being flexed at the knee, with the other one extended.

Other, far less common presentations are: footling presentation and knee presentation. In the footling presentation the lower extremities of the foetus are extended at one or both hips and knees, and in the knee presentation both lower extremities of the foetus are extended from the hips and one or both lower extremities are flexed at the knees.

Foetuses in breech position are at increased risk of perinatal mortality and morbidity. In the past, perinatal mortality and morbidity have been estimated to be three to five times that of comparable infants with vertex presentation, also after excluding prematurity and congenital anomalies, trauma and hypoxia being the two most contributing factors. $^{4,5}$

\section{The history of management of breech delivery}

The management of breech presentation is one of the most frequently discussed clinical issues in obstetrics and has always been a dilemma for the obstetrician. ${ }^{6-8}$ The importance of gentle delivery of the after coming foetal head was emphasized by Jacques Guillemeau (1550-1613), but François Mauriceau (1637-1709) has popularised the manoeuvre. The manoeuvre is still known as the 'Mauriceau manoeuvre'. In the $18^{\text {th }}$ century William Smellie first successfully applied forceps to the aftercoming head, but Edmund Piper, in 1924, developed another forceps, solely made to be used for the aftercoming head, still known as the 'Piper forceps' and used till this day.

In 1935 Erich Bracht presented the manoeuvre that is named after him, at the Berlin Gynaecological Society. ${ }^{9}$ According to Bracht, the breech is allowed to deliver sponta- 
neously up to the umbilicus without pushing or pulling. The knee-extended legs of the flexed breech are not brought down. The body and extended legs are then grasped in both hands, with the fingers around the lower back and the thumbs around the posterior aspect of the thighs, while the upward and anterior rotation of the body is maintained. When the anterior rotation is nearly complete the body is held, not pressed, against the mother's symphysis using only a force equivalent to the weight of that portion of the baby already born. The mere maintenance of this position, added to the uterine contractions and, if necessary, gentle suprapubic pressure by an assistant, allowes the baby's head to deliver spontaneously in full extension.

In 1953, Plentl and Stone reviewed the subject. ${ }^{10}$ They stated that numerous statistical analyses all over the world had established that the more the breech was manipulated and the earlier these manipulations were executed, the greater the foetal mortality and morbidity, not to mention the maternal injuries, such as extensive perineal tears. Therefore they argued that manipulation should either be avoided, or reduced to a minimum whenever possible. In the Netherlands, the Bracht manoeuvre is slightly modified: the obstetrician waits until the lower edge of the scapula are visible, then the baby is rotated around the symphysis and, if needed, suprapubic pressure is given.

Vaginal delivery has always been looked upon as an obstetric art and the preferred way of delivery until the late 1950's. ${ }^{11,12}$ In 1959, Wright advocated a planned caesarean section in breech presentation above 35 weeks of gestation, to reduce perinatal mortality and morbidity. ${ }^{13}$ Before the Term Breech Trial cohort studies showed lower neonatal mortality and morbidity in planned caesarean section compared to planned vaginal birth for the term breech foetus. ${ }^{14,15}$ Two randomised controlled trials and a Cochrane metaanalysis of these trials failed to confirm these findings, but both trials had very small sample sizes. Therefore, continuation of research to determine whether a caesarean section for the term breech reduces adverse perinatal outcome, was regarded to be of great importance..$^{15-18}$

\section{The Term Breech Trial (TBT)}

In October 2000, the results of the Term Breech Trial were published. The Term Breech Trial was a randomised controlled multicentre study, conducted to determine whether a planned caesarean section or a planned vaginal delivery is the best mode of delivery for selected foetuses in breech presentation at term. A total of 121 centres in 26 countries participated, the Atrium Medical Centre Parkstad being the only Dutch hospital. In total, 2088 women with a singleton foetus in frank or complete breech presentation were randomly assigned to either a planned caesarean section or a planned vaginal delivery. The analysis was based on intention to treat. The study showed that the risk of perinatal or neonatal mortality or serious neonatal morbidity was three times lower in the planned caesarean section group compared to the planned vaginal delivery group $(1.6 \%$ vs. $5.0 \%, 95 \%$ CI 0.33 [0.19-0.56]). ${ }^{19}$ A Lancet commentary concluded that "there was no more room for disagreement on breech delivery". ${ }^{20}$ 
At two years of age no reduction in risk of death or neurodevelopmental delay was found after planned caesarean section compared to planned vaginal delivery for term breech presentation. ${ }^{21}$

\section{Maternal mortality and morbidity}

Caesarean delivery has long been believed to increase the risk of maternal death, and there are enough data to support that belief. Maternal mortality after caesarean section is estimated to be three to seven times higher than after vaginal birth. ${ }^{22-24}$ Without denying the importance of those findings some remarks have to be made. Firstly, elective caesarean section is not separated in the analyses from emergency caesarean section. ${ }^{22-24}$ Secondly, since maternal death is quite rare, data sets used to look for trends that stretch back for years, and may include women whose care was provided according to a now outmoded standard..$^{25,26}$ Thirdly, in developed countries the risks associated with surgery have diminished over time, and this seems especially true for elective caesarean delivery. Recent data even demonstrate lower mortality in elective caesarean delivery than in vaginal delivery. ${ }^{27,28}$ On the other hand, most reports on maternal mortality discount the risk of death in subsequent pregnancies, due to increased risks of uterine rupture, placenta praevia, placenta accreta and ectopic pregnancy. ${ }^{29-31}$ In the Term Breech Trial there was no difference in serious maternal complications between the planned caesarean section group and the planned vaginal delivery group. ${ }^{19}$ In the follow-up two years after delivery no difference was found as well, neither in maternal health outcomes, nor in mothers' views of their childbirth experiences. ${ }^{32,33}$

\section{Situation in the Netherlands}

In the Netherlands vaginal delivery of breech presentation was common practice until the publication of the Term Breech Trial in the Lancet in October 2000 . Roughly $25 \%$ of all term breech presentations were delivered by planned caesarean section, $25 \%$ by caesarean section during labour and $50 \%$ were delivered vaginally. This policy was considered to be safe and vaginal breech delivery in a selected population was supported in the guideline 'breech presentation' of the Dutch Society of Obstetrics and Gynaecology.

Immediately after the publication of the Term Breech Trial, several Dutch commentaries on the study were published, some disputing the results more than others. ${ }^{34-38}$ After extensive discussions, the Dutch guideline was changed and accepted in April 2001. The revised guideline states that the possibility of an elective caesarean section should be discussed with the patient. ${ }^{39}$ This guideline is currently under investigation and may be adapted shortly. 


\section{Aim of this thesis}

The aim of this thesis was to address the following questions:

1. How fast did obstetric breech delivery management in the Netherlands change after publication of the results of the Term Breech Trial (TBT)? (chapter 2)

2. Are the short term neonatal and maternal results in a well-defined non-randomised group of Dutch pregnant women with a term foetus in breech presentation comparable with those in the Term Breech Trial? (chapter 3)

3. Does birth weight influence neurodevelopmental outcome of children at two years of age after planned vaginal delivery for breech presentation at term? (chapter 4)

4. Are the maternal health outcomes and mothers' views of their childbirth experience two years after term breech delivery, in a well-defined non-randomised group of Dutch pregnant women with a term foetus in breech presentation, comparable with those in the Term Breech Trial? (chapter 5 and 6 )

5. Is there a difference in neonatal mortality and morbidity between breech and cephalic presentations at term? (chapter 7)

6. How should we counsel a patient with a near term foetus in breech position about the preferred route of delivery based on the current national and international literature? (chapter 8) 


\section{References}

1. Hickok DE, Gordon DC, Milberg IA, Williams MA, Daling JR. The frequency of breech presentation by gestational age at birth: a large population-based study. Am J Obstet Gynecol 1992;166:851-2.

2. Westgren M, Edvall H, Nordström L, Svalenius E. Spontaneous cephalic version of breech presentation in the last trimester. BJOG 1985;92:19-22.

3. Collea JV. Current management of breech presentation. Clin Obstet Gynecol 1980;23:525-31.

4. Fischer-Rasmussen W, Trolle D. Abdominal versus vaginal delivery in breech presentation. Acta Obstet Gynecol Scand 1967;46:69-76.

5. Rovinsky JJ, Miller JA, Kaplan S. Management of breech presentation at term. Am J Obstet Gynecol 1973;115:497-513.

6. Ghosh MK. Breech presentation, evolution of management. J Reprod Med 2005;50:108-16.

7. Confino E, Gleicher N, Elrad H, Ismajovich B, David MP. The breech dilemma. Obstet Gynecol Surv 1985;40:330-7.

8. Myers SA, Gleicher N. Breech delivery: why the dilemma? Am J Obstet Gynecol 1987;156:6-10.

9. Bracht E. Zur manualhilfe bei beckenendlage. Ztschr Geburtsh Gynäk 1936;112:271.

10. Plentl AA, Stone RE. The Bracht maneuver. Obstet Gynecol Surv 1953:8:313-25.

11. Greenhill JP (editor). The Year Book of Obstetrics and Gynecology. Chicago, Year Book Medical Publishers, 1975. p 160-1.

12. Bowes WA, Taylor ES, O'Brien M, Bowes C. Breech delivery: evaluation of the method of delivery on perinatal results and maternal morbidity. Am J Obstet Gynecol 1979;135:965-73.

13. Wright RC. Reduction of perinatal mortality and morbidity in breech delivery through routine use of cesarean section. Obstet Gynecol 1959;14:758-63.

14. Cheng M, Hannah ME. Breech delivery at term: a critical review of the literature. Obstet Gynccol 1993;82:605-18.

15. Gifford DS, Morton SC, Fiske M, Kahn K. A meta-analysis of infant outcomes after breech delivery. Obstet Gynecol 1995;85:1047-54.

16. Gimovsky ML, Wallace RL. Schifrin BS, Paul RH. Randomized management of the nonfrank breech presentation at term: a preliminary report. Am J Obstet Gynccol 1983;146:34-40.

17. Collea JV, Chein C, Quilligan EJ. The randomized management of term frank breech presentation: a study of 208 cases. Am J Obstet Gynccol 1990;137:235-44.

18. Hofmeyr GJ, Hannah ME. Planned caesarean section for term breech delivery. Cochrane Database Syst Rev 2000;(2): CD000166.

19. Hannah ME, Hannah WJ, Hewson SA, Hodnett ED, Saigal S, Willan AR. Planned caesarean section versus planned vaginal birth for breech presentation at term: a randomised multicentre trial. Lancet 2000;356:1375-83.

20. Lumley J. Any room left for disagreement about assisting breech births at term? Lancet 2000;356:136970 .

21. Whyte H, Hannah ME, Saigal S, Hannah WJ, Hewson S, Amankwah $\mathrm{K}$ et al, Outcomes of children at 2 years after planned cesarean versus planned vaginal delivery for breech presentation at term: the international randomized Term Breech Trial. Am J Obstet Gynecol 2004;191:864-71.

22. Schuitemaker N, van Roosmalen J, Dekker G, van Dongen P, van Geijn H, Bennebroek Gravenhorst J. Maternal mortality after cesarean section in The Netherlands. Acta Obstet Gynecol Scand 1997;75:3324.

23. Jolly J, Walker J, Bhabra K. Subsequent obstetric performance related to primary mode of delivery. Br J Obstet Gynaecol 1999;106:227-232.

24. Hall M, Bewley S. Maternal mortality and mode of delivery. Lancet 1999;354:776.

25. Sachs BP, Yeh J, Acker D, Driscoll S, Brown DA, Jewett JF. Cesarean section-related mortality in Massachusetts, 1954-1985. Obstet Gynecol 1988;71:385-8.

26. Lilford RJ, van Coeverden de Groot HA, Moore PJ, Bingham P. The relative risks of caesarean section (intrapartum and elective) and vaginal delivery: a detailed analysis to exclude the effects of medical disorders and other acute pre-existing physiological disturbances. Br J Obstet Gynaecol 1990;97:883-92.

27. Yoles 1 , Maschiach S. Increased maternal mortality in cesarean section as compared to vaginal delivery? Time for re-evaluation. Am J Obstet Gynecol 1988;178:Suppl:S78. abstract. 
28. Lucas DN, Yentis SM, Kinsella SM et al. Urgency for cesarean section: a new classification. J R Soc Med 2000;93:346-50.

29. Hemminki E, Meriläinen J. Long-term effects of cesarean sections: ectopic pregnancies and placental problems. Am J Obstet Gynecol 1996;174:1569-74

30. Lydon-Rochelle M, Holt VL, Easterling TR, Martin DP. Risk of uterine rupture during labour among women with a prior caesarean section. NEJM 2001;345:3-8.

31. Gilliam $M$, Rosenberg D, Davis $F$. The likelihood of placenta previa with greater number of cesarean deliveries and higher parity. Obstet Gynecol 2002;99:976-80.

32. Hannah ME, Whyte H, Walter J, Hewson S, Amankwah $\mathrm{K}$, Cheng $\mathrm{M}$ ct al. Maternal outcome at 2 years after planned caesarcan section versus planned vaginal birth for breech presentation at term: the international Term Breech Trial. Am J Obstet Gynecol 2004;191:864-71.

33. Hodnett ED, Hannah ME, Ilewson S, Whyte H, Amankwah $\mathrm{K}$, Cheng $\mathrm{M}$ et al. Mothers' views of their childbirth experiences 2 years after planned caesarean versus planned vaginal birth for breech presentation at term, in the international randomized Term Breech Trial. J Obstet Gynaecol Can 2005;27:224-31.

34. Verhoeven ATM. Keizersnede bij stuitligging? Medisch Contact 2000;48:1703.

35. de Leeuw JP, Verhoeven ATM. De 'Term Breech Trial' (TBT), 5 maanden verder. NTOG 2001;114:148-9.

36. Roumen FJME, Nijhuis JG. De aterme stuitligging: keuze voor keizersnede. NTVG 2001;145:1533-6.

37. Buitendijk SE. Problemen met de stuit. NTOG 2001;114:230-5.

38. van Roosmalen $\mathrm{J}$, Rusendaal $\mathrm{F}$. There is still room for disagreement about vaginal delivery of breech infants at term. BJOG 2002;109:967-9.

39. Committee for Quality NVOG (Dutch Society of Obstetrics and Gynaecology) Guideline 7- Breech presentation. July 2001 . Utrecht. 
Recent trends in breech delivery in the Netherlands

\author{
Molkenboer JFM \\ Bouckaert PXJM \\ Roumen FJME
}

BJOG 2003;110:948-51 


\begin{abstract}
The effect of publication of the results of the Term Breech Trial in October 2000 on the mode of delivery of babies in breech presentation in the Netherlands was subject of this study. The results showed an immediate amplifying impact on top of the already existing trend of rising caesarean section rates for term singleton breech presentations. The willingness of obstetricians in the Netherlands to adopt the conclusions of the Term Breech Trial so quickly originate from scientific, legal, psychological and emotional sources. The same amplifying impact applied for all non-term breeches and breeches from multiple gestations, but not for babies in other than breech presentation.
\end{abstract}




\section{Introduction}

The obstetrical care system in the Netherlands is well known for its selection system, resulting in a high percentage of deliveries by home practising midwives. This selective approach has also been used by obstetricians to plan the mode of delivery of breech presentations, which resulted in low caesarean section rates in the past. In October 2000, the results of the Term Breech Trial were published.' These results questioned the safety for the baby of planned vaginal delivery, giving way to intensive and emotional discussions among obstetricians in the Netherlands. ${ }^{2}$ We studied the effect of the Term Breech Trial publication on the mode of delivery of breech presentations in the Netherlands.

\section{Methods}

During the years 1996 through 2001, all infants born in breech presentation were analysed for their mode of delivery. Data were collected from the LVR-2, a nationwide registration system of practically all hospital deliveries, including all breech deliveries and caesarean sections performed in the Netherlands. ${ }^{3}$ Breeches were classified in a group of term singleton infants and an other group of non-term infants and infants from a multiple gestation. Abdominal deliveries were subdivided in elective and emergency caesarean sections. Abdominal deliveries performed for children in other than breech presentation were also recorded and analysed according to elective and emergency caesarean sections.

\section{Results}

During recent years, the total number of children born in the Netherlands fluctuated around 200,000. An increasing number of these children were delivered in the hospital under supervision of the obstetrician, and were registered in the LVR-2, from $53.6 \%$ in 1996 up to $60.6 \%$ in 2001. During this period, the total number of caesarean deliveries steadily increased from 18,087 in 1996 , which is $9.5 \%$ of all deliveries in the Netherlands and $17.7 \%$ of hospital deliveries, up to 28,689 in 2001 , accounting for $14.0 \%$ of all deliveries and $23.2 \%$ of hospital deliveries.

As shown in Figure 1, the percentage of term singleton infants in breech presentation born by caesarean section gradually increased from $44.9 \%$ in 1996 up to $57.4 \%$ in 2000 , and then steeply rose to $80.8 \%$ in 2001 . Most of these caesarean sections were elective. The same trend was seen in the other group of non term breech infants and breech infants from a multiple gestation. In this group the percentage of caesarean sections increased from $42.2 \%$ in 1996 up to $49.8 \%$ in 2000 , with a maximum of $58.6 \%$ in 2001 (Figure 2). Most caesarean sections were also elective. 
Term singleton breeches

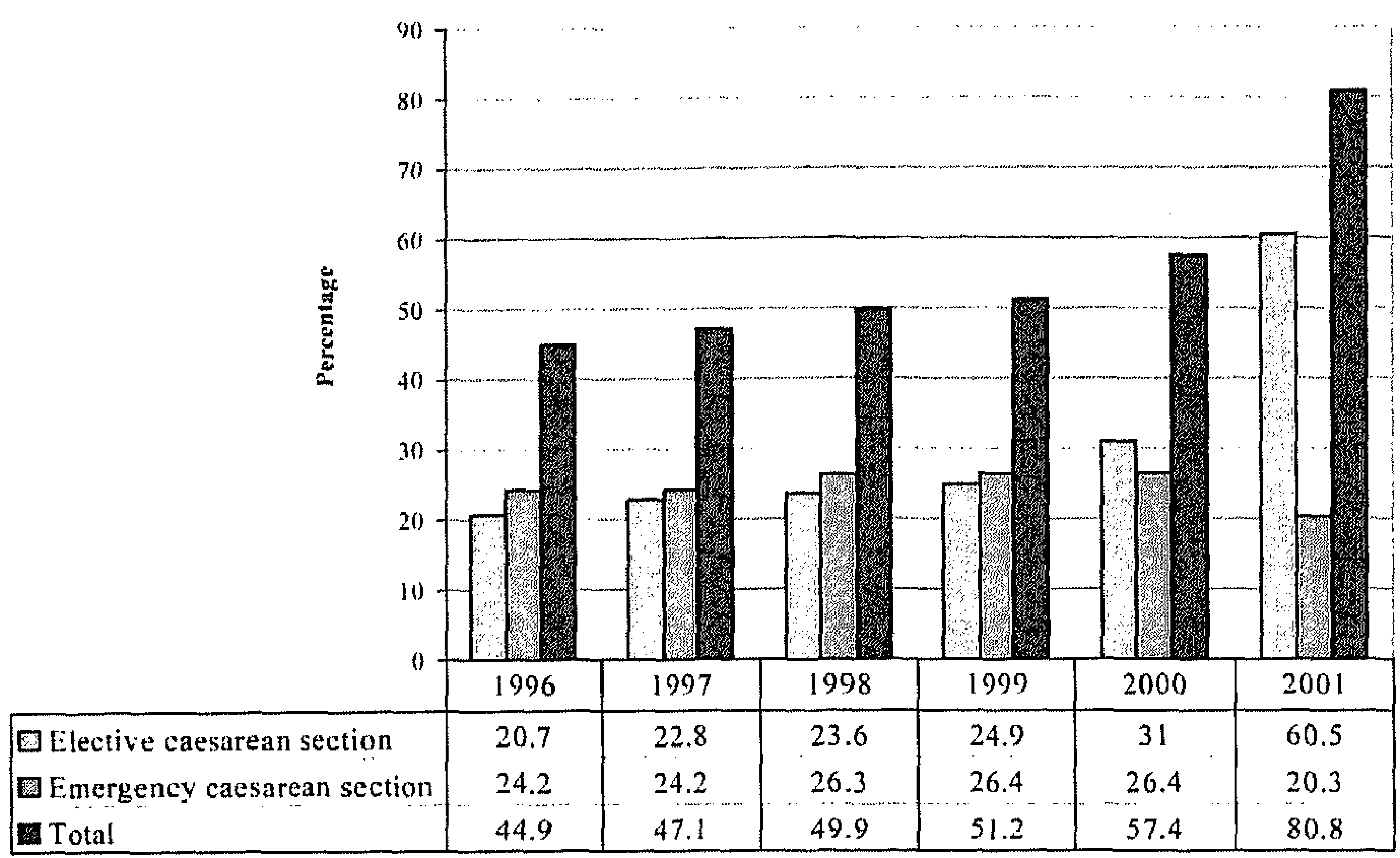

Figure 1. Term singleton breeches.

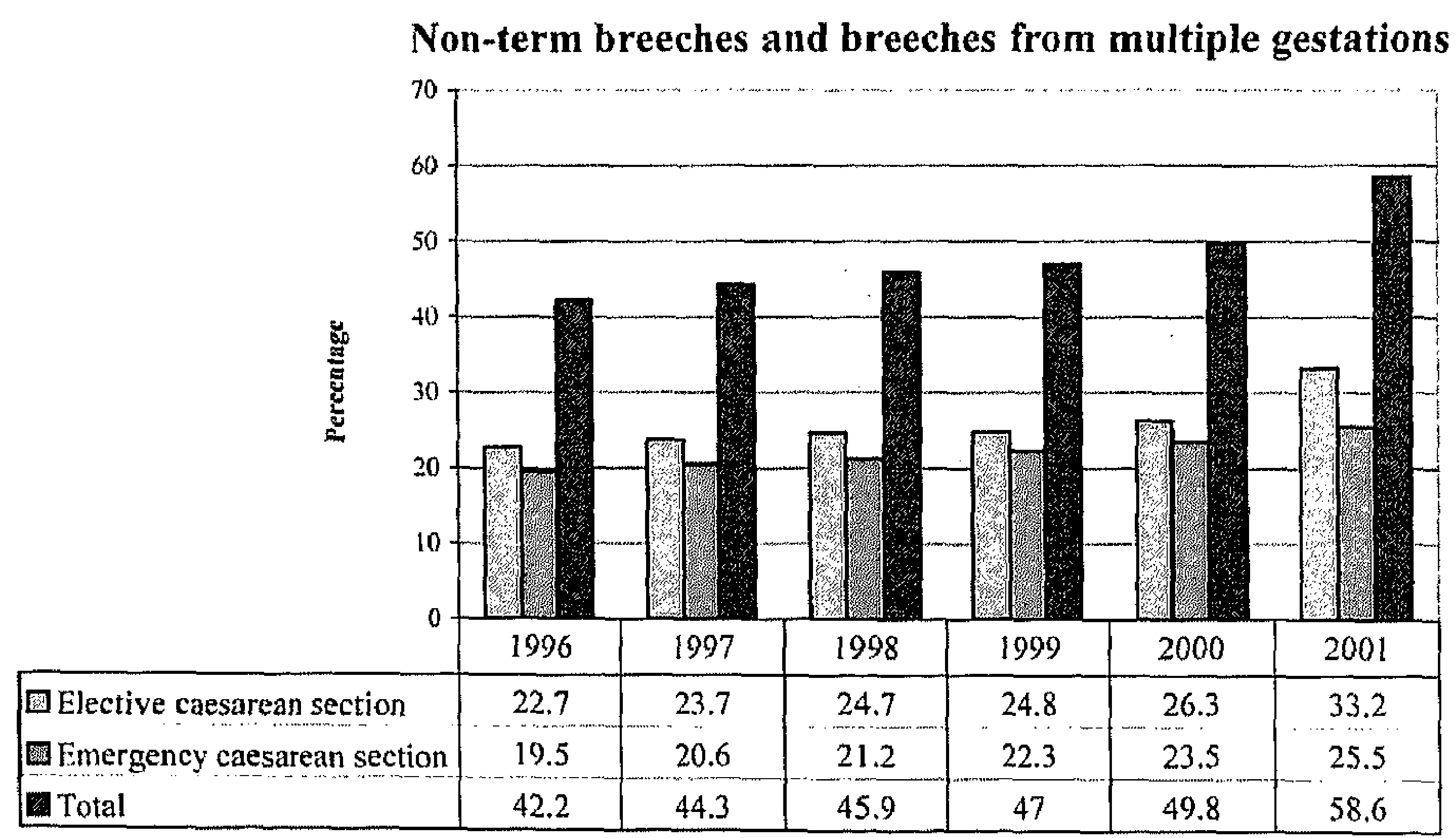

Figure 2. Non-term breeches and breeches from multiple gestations. 
The percentage of children in other than breech presentation and born by caesarean section steadily increased from $13.8 \%$ in 1996 up to $16.6 \%$ in 2001 (Figure 3). Both the elective and emergency caesarean sections showed this steady increase.

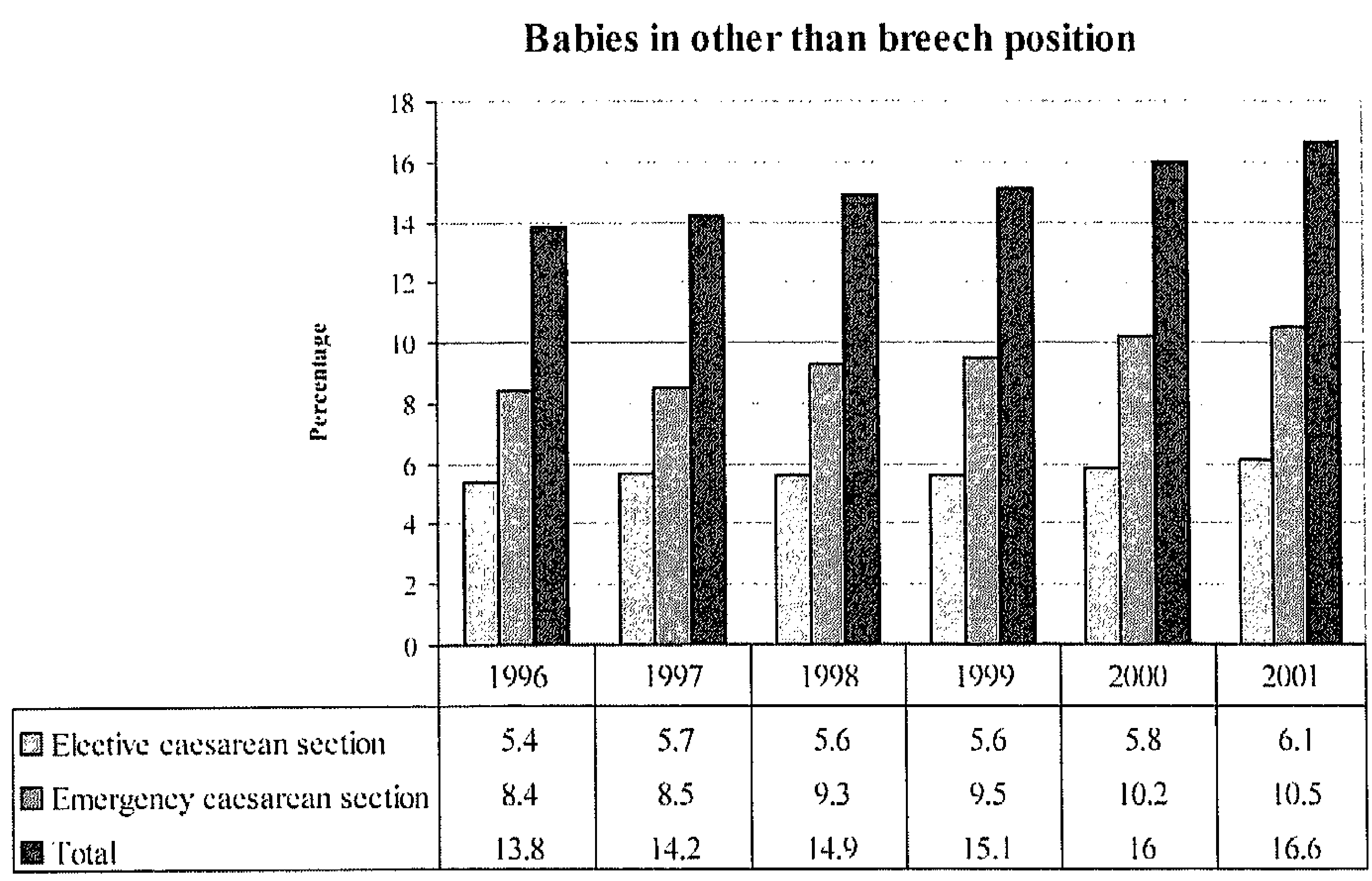

Figure 3. Babies in other than breech position

\section{Discussion}

For many years, the obstetrical standard of care in the Netherlands was planned vaginal delivery of carefully selected breeches, which was considered to be safe. ${ }^{4}$ In a 1998 guideline of the Dutch Society of Obstetrics and Gynaecology it was stated, that routine performance of a caesarean section for merely breech presentation was not preferable. Nevertheless, a slight but gradual increase was found of both elective and emergency caesarean section rates for term singleton breeches during the final years of the last century. Publication of two meta-analyses on this subject, concluding that an elective caesarean section is the safest option for the baby, and medico-legal arguments, may be held responsible for this development. ${ }^{5,6}$

Publication of the Term Breech Trial findings in October 2000 resulted in a moderate increase of elective caesarean sections in 2000 , probably due to the limited effect of only the months November and December, followed by a steep increase up to $60.5 \%$ in 2001. The Term Breech Trial appeared to have an amplifying effect on the already existing trend of rising caesarean section rates for the term singleton breech baby. The percentage of emergency caesarean sections decreased in 2001, caused by fewer attempts for a vaginal delivery.

The willingness of obstetricians in the Netherlands to adopt the conclusions of the Term Breech Trial so quickly was unprecedented, posing some questions as to the possible reasons. 
First of all, the striking results of the Term Breech Trial, whose design was judged to apply to high standards of evidence based medicine, were immediately and extensively discussed within the Dutch Society of Obstetrics and Gynaecology, soon leading to a revised guideline stating that an elective caesarean section is an approved mode of delivery for a term singleton breech presentation.

Another important factor was that obstetricians in the Netherlands are legally obliged to inform their patients about the Term Breech Trial results and to discuss with them the preferred mode of delivery. The better neonatal results of an elective caesarean section, however, compromise a balanced judgement on the preferred mode of delivery by the pregnant woman, as she only wants the best for her unborn child without thinking about the consequences of an elective caesarean section for her and for possible pregnancies in the future.

Moreover, many obstetricians felt reassured in their opinion of the unpredictability and the hazards of vaginal breech delivery by the Term Breech Trial results. Until then, this opinion was highly unpopular in the Netherlands, known for its conservative obstetrical approach of breech delivery. Finally, other obstetricians were relieved to have scientific evidence sparing them from the stress of an attempted vaginal breech delivery.

The amplifying effect in 2001 on the already existing trend of rising caesarean section rates for non-term breeches and breech infants from multiple gestations is remarkable, as the Term Breech Trial was restricted to only term singleton breeches. This finding is exemplary for emotional and not evidence based medicine. Fortunately, the amplifying effect is yet to be seen in the existing trend of rising caesarean section rates for children in other than breech presentation.

\section{Conclusion}

Publication of the results of the Term Breech Trial in October 2000 had an immediate amplifying impact on the already existing trend of rising caesarean section rates for all breech presentations in the Netherlands, caused by scientific, legal, psychological and emotional reasons. 


\section{References}

1. Hannah ME, Hannah WJ, Hewson SA, Hodnett ED, Saigal S, Willan AR. Planned caesarean section versus planned vaginal birth for breech presentation at term: a randomised multicentre trial. Lancet 2000;356:1375-83.

2. Roumen FJME, Nijhuis JG. The term breech trial; choice for caesarean section. Ned Tijdschr Geneeskd 2001;145:1533-6.

3. Elferink-Stinkens PM, van Hemel OJ, Brand R, Merkus JM. The perinatal database of the Netherlands. Eur J Obstet Gynecol Reprod Biol 2001;94:125-38.

4. Roumen FJME, Luyben AG. Safety of term vaginal breech delivery. Eur J Obstel Gynecol Reprod Biol 1991:40:171-7.

5. Cheng $M$, Hannah $M$. Breech delivery at term: a critical review of the literature. Obstel Gynecol 1993;82:605-18.

6. Giftord DS, Morton SC, Fiske M, Kahn K. A meta-analysis of infant outcomes after breech delivery. Obstet Gynecol 1995;85:1047-54. 


\title{
Moderate neonatal morbidity after vaginal term breech delivery
}

\author{
Molkenboer JFM \\ Reijners EPJ \\ Nijhuis JG \\ Roumen FJME
}

J Matern Fetal Neonatal Med 2004;16:357-61 


\begin{abstract}
Objective: Comparison of the results of term breech births in our clinic with the Term Breech Trial (TBT).

Material and Methods: During the investigation period prospective data were collected on all deliveries of a term baby in breech presentation. Some pregnant women were included in the TBT and randomised in a planned caesarean section (CS) group and a planned vaginal delivery (VD) group. The remaining non-randomised women were divided in a primary CS group and a started VD group. Neonatal and maternal mortality and morbidity were analysed retrospectively, according to the intended mode of delivery.

Results: Neonatal or maternal mortality occurred in none of the groups. Neither in the randomised group nor in the non-randomised group significant differences in serious neonatal and maternal morbidity were observed between the intended caesarean section group and the group that started vaginal delivery. However, in the non-randomised group moderate neonatal morbidity was significantly lower in the primary CS group than in the started VD group.

Conclusion: The differences in moderate neonatal morbidity support the conclusion of the TBT, that primary caesarean section may be safer for the term breech baby than a trial of vaginal labour.
\end{abstract}




\section{Introduction}

The results of the Term Breech Trial (TBT) have demonstrated that delivery of the selected term breech foetus is safer by planned caesarean section (CS) than by planned vaginal delivery (VD).' We participated in this trial, but included only a small part of our total term breech population. Therefore, we were interested not only in the results of our group of randomised patients, but also in the results of the pregnant women who were not randomised during the trial period. Such an investigation may answer the question, whether or not the results of the TBT are applicable to our own clinic in a nonrandomised population.

\section{Patients and Methods}

From July 20, 1998 until April 21, 2000 we participated in the TBT. ${ }^{1}$ After signing the informed consent, the participating women were according to the TBT protocol assigned to a planned caesarean section group (planned CS group) or a planned vaginal delivery group (planned VD group). The non-randomised group included all pregnant women who did not participate in the TBT in the same period. In consultation with her obstetrician, the expectant mother chose to have a caesarean section (primary CS group) or a trial of vaginal delivery (started VD group). All caesarean sections were performed at a gestational age of 38 weeks or more. The vaginal deliveries were managed according to the usual procedures in our department, which followed the guidelines of the TBT protocol. ${ }^{2}$ Pelvic dimensions were assessed by means of internal investigation only, and not by $\mathrm{X}$ ray-pelvimetry or ultrasound.

The primary outcome was serious neonatal morbidity at less than 28 days of age, using the same criteria as in the TBT (as described in the results section). ${ }^{1}$ For the diagnosis of moderate neonatal morbidity the criteria were adapted, such as peripheral-nerve injury at birth but absent at discharge from hospital; a five minute Apgar score of 4-6; an umbilical artery $\mathrm{pH}$ between 7.00 and 7.10 , or a base deficit between 10 and 15 ; hypotonia not longer than two hours; admission to the neonatal intensive care unit during two to four days, or intubation and ventilation in this unit with a maximum of 24 hours, and tube feeding during two to four days.

The secondary outcome was maternal morbidity during the first six weeks post partum. Again, to define serious maternal morbidity the same criteria were used as in the TBT (as described in the results section). For moderate maternal morbidity the criteria were also adapted, such as post partum haemorrhage between 1000 and $1500 \mathrm{ml}$; blood transfusion without haemorrhage post partum (blood loss $<1000 \mathrm{ml}$ ); an incomplete perineal rupture; antibiotics post partum; wound haematoma, and early depression. We also assessed the number of days the women spend in the hospital after delivery. All data were collected retrospectively.

Statistical analysis was performed using chi-square test and Fisher's exact test. A twosided $\mathrm{p}$-value of less than 0.05 was considered significant. 


\section{Results}

From a total of 238 pregnant women with a term breech presentation, $35(15 \%)$ agreed to participate in the TBT (randomised group), the other 203 pregnant women $(85 \%)$ did not participate (non-randomised group). Two babies in the non-randomised group were born with lethal congenital anomalies and therefore excluded. The intended and the actual mode of delivery of all women are described in Figure 1. Table 1 shows why these 201 pregnant women were not randomised. Base characteristics of both the primary CS group and the started VD group of the non-randomised women were identical, except a significant difference in gestational age (Table 2).



Figure 1. The randomised and non-randomised study population according to the intended mode of delivery.

Table 1. Reasons for non-randomisation in the TBT of pregnant women with a term breech baby.

\begin{tabular}{lcccc}
\hline & Primary CS group & Started VD group & Tolal & Percentage \\
\hline Prefers vaginal delivery & 3 & 77 & 80 & 39.8 \\
Prefers caesarean section & 22 & 0 & 22 & 10.9 \\
No answer & 2 & 13 & 15 & 7.5 \\
$\quad$ Subtotal informed (and refused) & 27 & 90 & 117 & 58.2 \\
Not eligible & 18 & 3 & 21 & 10.5 \\
Not asked & 3 & 30 & 33 & 16.4 \\
Unknown breech & 0 & 30 & 30 & 14.9 \\
$\quad$ Subtotal not informed & 21 & 63 & 84 & 41.8 \\
Total & 48 & 153 & 201 & 100.0 \\
\hline
\end{tabular}


Table 2. Base characteristics of the non-randomised group of pregnant women according to women who underwent a primary caesarcan section (Primary CS group) and women who were allowed to start a vaginal delivery (Started VD group).

\begin{tabular}{|c|c|c|c|c|}
\hline & & $\begin{array}{l}\text { Primary CS group } \\
\qquad(\mathrm{N}=48)\end{array}$ & $\begin{array}{l}\text { Started VD group } \\
\qquad(\mathrm{N}=153)\end{array}$ & p-value \\
\hline \multirow[t]{2}{*}{ Age of the mother } & $<35$ years & 41 & 131 & \multirow{2}{*}{ NS } \\
\hline & $\geq 35$ years & 7 & 22 & \\
\hline \multirow[t]{2}{*}{ Parity } & nulliparous & 31 & 104 & \multirow{2}{*}{ NS } \\
\hline & multiparous & 17 & 49 & \\
\hline \multirow{2}{*}{ Gestational age at delivery } & $<41$ weeks & 45 & 115 & \multirow{2}{*}{0.005} \\
\hline & $\geq 41$ weeks & 3 & 38 & \\
\hline \multirow[t]{3}{*}{ Type of breech } & firank & 41 & 125 & \multirow{3}{*}{ NS } \\
\hline & complete & 4 & 26 & \\
\hline & otherwise & 3 & 2 & \\
\hline \multirow[t]{2}{*}{ Birth weight baby } & $<2500$ grams & 2 & 5 & \multirow{2}{*}{ NS } \\
\hline & $\geq 4000$ grams & 7 & 9 & \\
\hline \multicolumn{2}{|c|}{$\geq 48$ hours admission before labour } & 2 & 4 & NS \\
\hline
\end{tabular}

NS, not significant.

\section{Randomised group}

In the randomised group no perinatal mortality or serious neonatal morbidity was detected. One baby from the planned VD group was born with a base deficit between 10 and 15 (12.4). There was no case of maternal mortality. One mother from the planned CS group had a D\&C for a retained placental rest two weeks after delivery. Two mothers from this group had a blood transfusion, whereas in one mother of the planned VD group a haemorrhage post partum $(>1000 \mathrm{ml})$ was diagnosed. No differences in total maternal morbidity between the planned CS group $(n=3 ; 14 \%)$ and the planned VD group $(n=1 ; 8 \%)$ were observed.

\section{Non-randomised group}

Also in the non-randomised group no case of perinatal mortality occurred. Table 3 summarises the number of children with serious and with moderate neonatal morbidity in both groups. There was no difference in serious neonatal morbidity between both groups. However, there was a significant difference in moderate neonatal morbidity at the cost of the started VD group $(\mathrm{p}=0.03$ ). Maternal mortality did not occur. Serious and moderate maternal morbidity are shown in Table 4.

There were no significant differences in maternal morbidity between both groups, except for the number of days spend in the hospital, which was significantly higher in the primary CS group $(\mathrm{p}<0.001)$. 
Table 3. Serious and moderate morbidity of the neonates in the non-randomised group of pregnant women who underwent a primary caesarean section (Primary CS group) or who were allowed to start a vaginal delivery (Started VD group).

\begin{tabular}{lccc}
\hline & $\begin{array}{c}\text { Primary CS group } \\
(\mathrm{N}=48)\end{array}$ & $\begin{array}{c}\text { Started VD group } \\
(\mathrm{N}=153)\end{array}$ & p-value \\
\hline Serious neonatal morbidity & 0 & 3 & \\
Umbilical artery pH $<7.0$ & 0 & 3 & \\
Base deficit $\geq 15$ & 1 & 0 & \\
Intubation and ventilation $\geq 24 \mathrm{~h}$ & 0 & 1 & 0.44 \\
Hypotonia $\geq 2 \mathrm{~h}$ & 0 & 2 & \\
Plexus lesion present at discharge & $1(2.1 \%)$ & $7(4.6 \%)$ & \\
Subtotal number of children & & & \\
Moderate neonatal morbidity & 0 & 1 & 17 \\
S min. Apgar score $4-6$ & 1 & 8 & \\
Umbilical artery pH $7.0-7.1$ & 0 & 3 & \\
Base deficit $10-15$ & 0 & 1 & 0.03 \\
Intubation and ventilation $<24 \mathrm{~h}$ & 0 & 1 & 0.02 \\
Hypotonia $<2 \mathrm{~h}$ & 1 & $25(16.3 \%)$ & \\
Tube feeding 2-4 days & $2(4.2 \%)$ & $32(20.9 \%)$ & \\
Plexus lesion absent at discharge & $3(6.3 \%)$ & \\
Subtotal number of children & & & \\
Total number of children & &
\end{tabular}

Table 4. Serious and moderate morbidity of the non-randomised pregnant women who underwent a primar? caesarean section (Primary CS group) or who were allowed to start a vaginal delivery (Started VD group).

\begin{tabular}{lccc}
\hline & $\begin{array}{c}\text { Primary CS group } \\
(\mathrm{N}=48)\end{array}$ & $\begin{array}{c}\text { Started VD group } \\
(\mathrm{N}=153)\end{array}$ & p-valu \\
\hline Serious maternal morbidity & & & \\
HPP $\geq 1500$ ml with transfusion & 2 & 5 & \\
Wound infection with (re)admission & 1 & 1 & \\
Fourth degree laceration & 0 & 1 & 0.64 \\
Subtotal number of mothers & $3(6.3 \%)$ & $7(4.6 \%)$ & \\
Moderate maternal morbidity & $2(2)$ & $6(3)$ & \\
HPP $1000-1500$ m! (with transfusion) & 6 & 12 & \\
Blood transfusion without HPP & 0 & 1 & \\
Third degree laceration & 0 & 2 & \\
Antibiotics post partum & 0 & 2 & 0.62 \\
Wound haematoma & 1 & $24(15.7 \%)$ & $<0.49$ \\
Early depression & $9(18.8 \%)$ & $31(20.3 \%)$ & \\
Subtotal number of mothers & $12(25.0 \%)$ & $67(43.8 \%)$ & $<001$ \\
Total number of mothers & $45(93.8 \%)$ & & \\
Hospital stay $\geq 5$ days & & & \\
\hline
\end{tabular}

HPP, haemorrhage post partum. 


\section{Discussion}

Beside positive comments, the results of the TBT have also received unbelief and criticism. ${ }^{3-5}$ In order to elucidate whether the TBT results are also applicable in our population, we evaluated the results of all term breech deliveries in our own clinic. However, we investigated not only serious neonatal morbidity, but also moderate forms of it. As in the TBT, the randomised group consisted exclusively of pregnant women who were judged to be eligible for a trial of vaginal delivery. The results in this group are not comparable with those in the non-randomised group, as many women in the nonrandomised group underwent a primary caesarean section for a medical, obstetrical or other reason, e.g. previous caesarean section or severe pre-eclampsia.

Both the randomised and the non-randomised group of pregnant women were analysed according to the intention-to-treat principle. Neither in the randomised, nor in the nonrandomised group significant differences in serious neonatal morbidity could be detected. These findings are conflicting with the results of the TBT. This is probably caused by the small number of neonates included in both study groups, as is the case in previous studies. ${ }^{6}$

A post hoc analysis calculated the research group should be at least three times larger (142 primary caesarean sections and 465 attempted vaginal deliveries) to become statistically significant (with a power of $80 \%$ and alpha $5 \%$ ). However, in the nonrandomised group moderate morbidity of the children was lower in the CS group. The absence of this finding in the randomised group can be explained by the very small number of patients included in this group, but also by the possibility that patients participating in clinical trials often perform better than non-participating patients. ${ }^{7}$

It must be stressed, that the clinical relevance of moderate neonatal morbidity is mostly low. In most cases we detected abnormal blood gasses, which are only slightly correlated to a sub-optimal condition of the newborn or hardly ever in cases where the Apgar score at $5 \mathrm{~min}$ is 7 or higher, as we found in most newborns. ${ }^{8}$

As earlier found in the TBT, in both study groups no significant difference in maternal morbidity was detected between the women who had a primary caesarean section and those who tried a vaginal delivery. However, the hospital stay of the mothers with a primary caesarean section was significantly longer.

Summarising, both in the randomised and in the non-randomised group with a term child in breech presentation we did not find the differences in serious neonatal morbidity as found in the TBT between the group who intended to have a caesarean section and the group who intended to deliver vaginally. There were, however, significant differences in moderate neonatal morbidity in the non-randomised group at the cost of the women who were allowed to try a vaginal delivery. We feel that next to information on the results of the TBT, the findings in the own clinic -although not reached under the same circumstances as the TBT- should be carefully discussed with the expectant mother. 


\section{References}

1. Hannah ME, Hannah WJ, Hewson SA, Hodnett FD, Saigal S, Willan AR. Planned caesarean section versus planned vaginal birth for breech presentation at term: a randomised multicentre trial. Lancet 2000;356:1375-83.

2. Hannah WJ, Allardice J, Amankwah $\mathrm{K}$ et al. The Canadian consensus on breech management at term. J Soc Obstet Gynecol Can 1994;16:1839-58.

3. Lumley J. Any room left for disagreement about assisting breech births at term? Lancet 2000;356:13689.

4. Hannah ME, Hannah WJ, Willan AR. Term breech trial Correspondence. Lancet 2001;357:225-8.

5. Bowes WA, Jr. Editorial comment. Obstet Gynecol Surv 2001;56:132-4.

6. Hofmeyr GJ. Hannah ME. Planned Caesarean section for term breech delivery. Cochrane Database Syst $\operatorname{Rev} 2000 ;(2): C D 000166$.

7. Lantos JD. The 'inclusion benefit' in clinical trials. J Pediatr 1999;134:130-1,

8. Dijxhoorn MJ, Visser GHA, Fidler VJ et al. Apgar score, meconium and acidaemia at birth in relation to neonatal morbidity in term infants. Br J Obstet Gynaecol 1986;93:217-22. 


\title{
Birth weight and neurodevelopmental outcome of children at 2 years of age after planned vaginal delivery for breech presentation at term
}

\author{
Molkenboer JFM \\ Roumen FJME \\ Smits LJM \\ Nijhuis JG
}

Am J Obstet Gynecol 2006;194:624-9 


\begin{abstract}
Objective: The purpose of this prospective cohort study was to determine whether planned vaginal delivery for the term singleton baby in breech position increases the risk of abnormal neurodevelopment at 2 years of age and to assess whether the effect is modified by birth weight.

Study design: At 2 years of age, all non-randomised children born in breech position during our participation in the Term Breech Trial were screened for abnormal neurodevelopment with the Ages and Stages Questionnaire.

Results: An Ages and Stages Questionnaire at 2 years of age was obtained in 183 of 203 children (90.1\%). Twenty-eight percent of these children showed one or more abnormal Ages and Stages Questionnaire domains. There were no differences in the risk of having abnormal Ages and Stages Questionnaire domains between planned vaginal delivery and planned caesarean section $(\mathrm{p}=0.99)$. There was, however, evidence of interaction between mode of delivery and birth weight, with significantly higher risk in neurodevelopmental delay in children with birth weight greater than $3500 \mathrm{~g}$ with planned vaginal birth (adjusted odds ratio for interaction term 3.37; 95\% confidence interval 1.14 to 9.95).

Conclusion: Based on the Ages and Stages Questionnaire results at 2 years of age, planned vaginal delivery is associated with an increased risk of neurodevelopmental delay at 2 years of age in term breech children with a birth weight greater than $3500 \mathrm{~g}$.
\end{abstract}




\section{Introduction}

The Term Breech Trial (TBT) clearly demonstrated that planned vaginal birth of a breech baby was associated with significantly increased perinatal or neonatal mortality or serious neonatal morbidity as compared to planned caesarean birth. ${ }^{1}$ No relation was detected with the estimated size or weight of the foetus. Also, in large retrospective meta-analyses, no information could be given on the role of birth weight on neonatal mortality and morbidity as a result of selection bias in the referred articles. ${ }^{2,3}$

After publication and discussion within the Dutch Society of Obstetrics and Gynaecology, the national guideline on breech delivery was changed. A planned caesarean section in case of a term breech presentation was now allowed. ${ }^{4}$ This resulted in an immediate amplifying impact on top of the already existing trend of rising caesarean section rates for term singleton breech presentations in the Netherlands from $57.4 \%$ in 2000 to $80.8 \%$ in $2001 .^{5}$

The question, however, remains whether late infant morbidity is also associated with the planned mode of delivery or due to other factors. Some large retrospective studies reported that late infant morbidity after breech delivery was increased with the planned vaginal mode of delivery. ${ }^{6,7}$ Other studies could not confirm these findings. ${ }^{8,9}$ Also in the TBT, no differences in neurodevelopmental delay in children at 2 years of age could be demonstrated according to the planned mode of delivery. ${ }^{10}$ The results were, however, not stratified by birth weight. In order to investigate the clinical significance of birth weight on the effect of mode of delivery on neurodevelopment in breech babies, we performed a prospective 2-year follow-up of all non-randomised breeches born in Atrium Medical Centre Heerlen during the period our department participated in the TBT.

\section{Material and methods}

From July 20, 1998 until April 21, 2000 we participated in the TBT.' During this period, we encountered 238 women with a term singleton baby in breech position at our hospital. Thirty-five women (14.7\%) were included in this trial. The remaining 203 women $(85.3 \%)$ did not participate in the randomised trial but consented to the neonatal results being analysed in the same way. ${ }^{11}$ The way the patients were assigned to deliver vaginally (planned VD group) or by caesarean delivery (planned CS group) has been described elsewhere. ${ }^{11}$ The planned vaginal deliveries were managed according to the usual procedures in our department, which followed the guidelines of the TBT protocol. $^{12}$

A 2-year follow-up of the same cohort of non-randomised children was performed according to the TBT protocol after having obtained informed consent by telephone. Therefore, infant questionnaires in Dutch were sent to the parents of the non-randomised breech babies approximately 23 months after the delivery. The questionnaire was to be completed within 23 and 25 months after birth. When the questionnaire was not returned after a month, a telephonic request was made to do so. If necessary, this procedure was repeated after two weeks. 
The questionnaire was an Ages and Stages Questionnaire (ASQ). This questionnaire has been developed in 1980 as an alternative screening assessment for infants and young children. ${ }^{13}$ The ASQ is a parent-completed child monitoring system which has been validated against the Bayley Scales of Infant Development as a screening tool for abnormal neurodevelopment. ${ }^{13,14}$ It contains five domains of child development (communication, gross motor skills, fine motor skills, problem-solving skills, and personalsocial skills). Each domain consists of 6 questions about what the child can or can not do. The response to each question is "yes", "sometimes" or "not yet" and is graded with 10,5 , or 0 points, respectively. The cut-off scores for the domains were used as described in the ASQ users guide. ${ }^{13}$ The ASQ is considered to be abnormal, if the score for any 1 of the 5 domains is abnormal. The sensitivity and specificity of the 24-month ASQ compared with the Bayley Scales of Infant Development is $87.5 \%$ and $79.3 \%$, respectively. ${ }^{13}$

In contrast with the 2-year TBT follow-up, a neurodevelopment assessment by a medical psychologist could not be performed in case of an abnormal score in any of the 5 domains because of a limited financial budget. So in this group, only the ASQ results could be used to estimate neurological morbidity. Special attention was paid to the medical history of children scoring 3 or more domains abnormal in the ASQ because this was considered suggestive of serious neurodevelopmental delay.

Analysis of differences in neurodevelopment after the two planned modes of delivery was performed by use of the chi-square test and logistic regression analysis (SAS version 8.02, SAS Institute, Cary, NC). Adjustment was made for birth weight (as a continuous variable, in grams), maternal age (up to 29 years, 30-34 years, 35 years and older), parity (nulliparous, multiparous), type of breech (frank, complete, or otherwise), gestational age (as a continuous variable, in days), and sex. In order to assess interaction between planned mode of delivery and birth weight, an interaction term of the 2 variables was used, with birth weight dichotomized as $3500 \mathrm{~g}$ or more or less than $3500 \mathrm{~g}$. A sample size calculation indicated that, to be able to detect a relative risk of 2.5 or greater for the planned VB group versus the planned CS group, with a power of $80 \%$, an alpha of $5 \%$ and a prevalence of the outcome of 0.30 , we would need to have at least 35 patients in the planned CS group and 105 patients in the planned VB group.

\section{Results}

During the study period, 238 term singleton breech babies were born of which 35 were randomised to the TBT and therefore excluded from the present analysis (Figure 1). The remaining 203 babies were not randomised for different reasons. ${ }^{11}$ In this group, 2 children were born with lethal congenital anomalies and excluded. ${ }^{11}$ Eighteen infants were lost to follow-up. This was due to various reasons: 3 children could not be included due to a language barrier of the parents; 4 families had moved and their new address was unknown; 2 families refused participation; 2 families did not return the questionnaire; and 7 families had no phone nor responded to mail.

Accordingly, in a total of 183 children (90.1\%) an ASQ was obtained. Forty-three women were planned for an elective caesarean section (planned CS group) and 140 women 


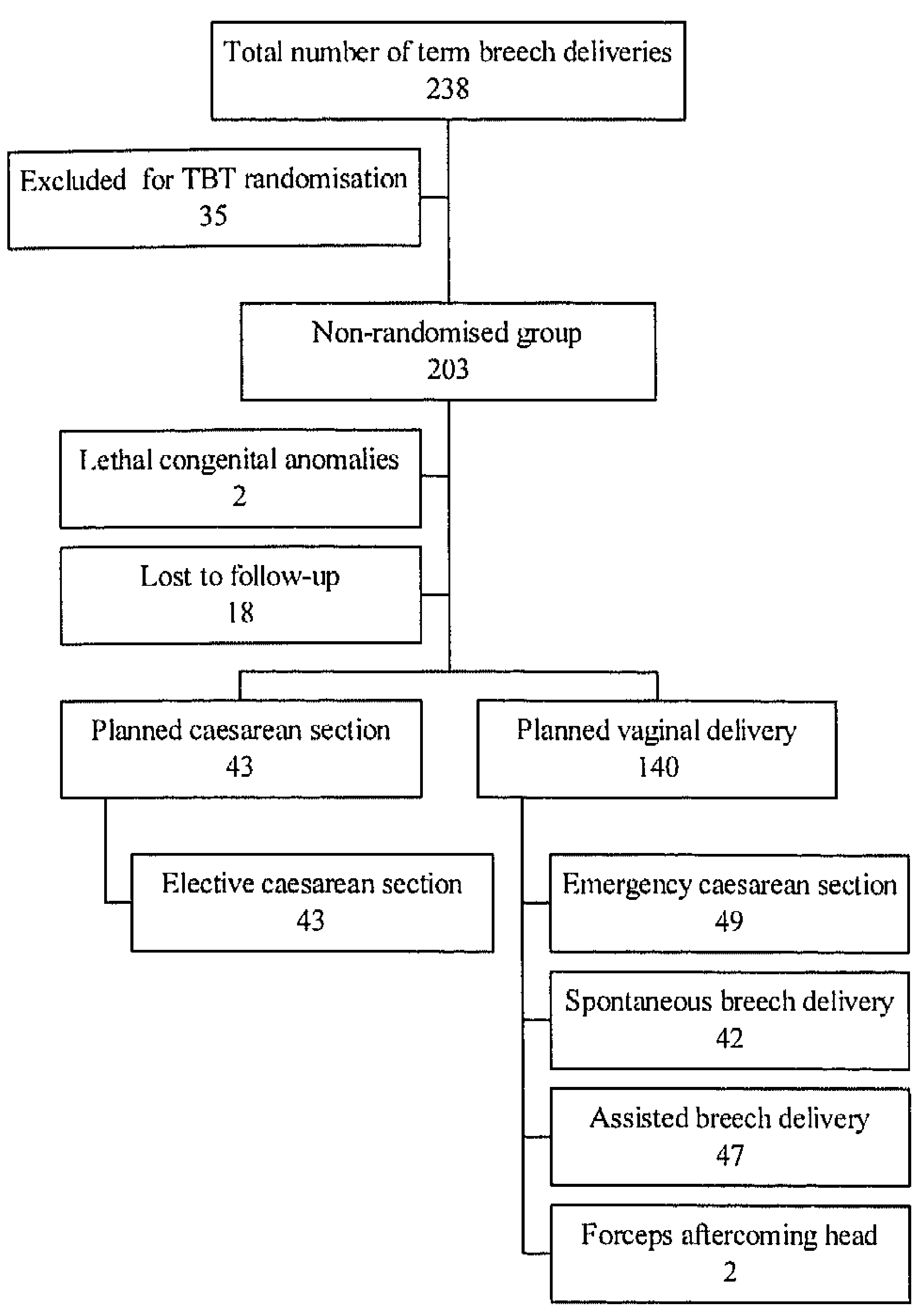

Figure 1. The non-randomised study population according to the planned and actual mode of delivery.

started vaginal delivery (planned VD group) (for the actual mode of delivery, see Figure 1).

As can be seen in Table 1, there were some differences between the planned CS group and the planned VD group, with respect to gestational age $(p<0.001)$, maternal age $(p=0.06)$ and type of breech $(p=0.05)$.

The number of children with 0 to 5 abnormal domains in the ASQ are shown in Table 2, according to the planned mode of delivery and birth weight. A total of 51 children $(27.9 \%)$ had 1 or more abnormal ASQ domains. Twelve of these $(27.9 \%)$ were in the planned CS group, and $39(27.9 \%)$ in the planned VD group $(p=0.99)$. 
However, as can be seen in Figure 2, there were differences in proportions of children with 1 or more abnormal ASQ domains between the 2 planned modes of delivery when children were stratified according to birth weight. Among children greater than $3500 \mathrm{~g}$, the risk of having 1 or more abnormal ASQ domains was $16 \%$ higher in the planned VD group than in the planned CS group. Among the lighter-weight babies, a reverse picture was visible but less pronounced.

Table 1. Characteristics of the non-randomised pregnant women according to women who underwent an elective caesarean section (planned CS group) and women were allowed to start a vaginal delivery (planned VD group).

\begin{tabular}{|c|c|c|c|c|}
\hline & & $\begin{array}{l}\text { Planned CS group } \\
\qquad(\mathrm{N}=43)\end{array}$ & $\begin{array}{l}\text { Planned VD group } \\
\quad(\mathrm{N}=140)\end{array}$ & p-value \\
\hline \multirow[t]{5}{*}{ Age of the mother $(y)$} & $20-24$ & 4 & 6 & \\
\hline & $25-29$ & 16 & 57 & \\
\hline & $30-34$ & 17 & 56 & $0.06(\mathrm{~ns})$ \\
\hline & $35-39$ & 4 & 21 & \\
\hline & $\geq 40$ & 2 & 0 & \\
\hline \multirow{2}{*}{ Parity } & nulliparous & 27 & 94 & \multirow{2}{*}{$0.6(\mathrm{~ns})$} \\
\hline & multiparous & 16 & 46 & \\
\hline Gestational age at delivery & $37^{0}-37^{+6}$ & 9 & 13 & \multirow{5}{*}{$<0.001$} \\
\hline \multirow[t]{4}{*}{ (wk) } & $38^{0}-38^{+6}$ & 24 & 20 & \\
\hline & $39^{0}-39^{+6}$ & 6 & 29 & \\
\hline & $40^{0}-40^{+6}$ & 1 & 43 & \\
\hline & $\geq 41^{\circ}$ & 3 & 35 & \\
\hline \multirow[t]{3}{*}{ Type of breech } & frank & 37 & 114 & \multirow{3}{*}{$0.05(\mathrm{~ns})$} \\
\hline & complete & 3 & 24 & \\
\hline & otherwise & 3 & 2 & \\
\hline \multirow[t]{5}{*}{ Birth weight baby (g) } & $<2500$ & 1 & 4 & \multirow{5}{*}{$0.33(\mathrm{~ns})$} \\
\hline & $2500-2999$ & 8 & 34 & \\
\hline & $3000-3499$ & 19 & 60 & \\
\hline & $3500-3999$ & 8 & 33 & \\
\hline & $\geq 4000$ & 7 & 9 & \\
\hline
\end{tabular}

Table 2. Number of children with abnormal domains (0-5) in the Ages and Stages Questionnaire (ASQ) according to the planned mode of delivery (planned caesarean section or planned vaginal delivery) and the birth weight.

\begin{tabular}{lcccccccccccc}
\hline & \multicolumn{4}{c}{$\begin{array}{c}\text { Abnormal ASQ domains } \\
\text { Planned CS group }\end{array}$} & \multicolumn{4}{c}{$\begin{array}{c}\text { Abnormal ASQ domains } \\
\text { Planned VD group }\end{array}$} \\
\hline Birth weight baby & 0 & 1 & 2 & 3 & 4 & 5 & 0 & 1 & 2 & 3 & 4 & 5 \\
$<2500 \mathrm{~g}$ & 0 & 0 & 1 & 0 & 0 & 0 & 4 & 0 & 0 & 0 & 0 & 0 \\
$2500-2999 \mathrm{~g}$ & 6 & 1 & 1 & 0 & 0 & 0 & 24 & 5 & 4 & 0 & 0 & 1 \\
$3000-3499 \mathrm{~g}$ & 14 & 3 & 2 & 0 & 0 & 0 & 49 & 6 & 1 & 1 & 1 & 2 \\
$3500-3999 \mathrm{~g}$ & 6 & 2 & 0 & 0 & 0 & 0 & 20 & 7 & 4 & 2 & 0 & 0 \\
$\geq 4000 \mathrm{~g}$ & 5 & 1 & 0 & 0 & 0 & 1 & 4 & 2 & 0 & 2 & 1 & 0 \\
Total number of children & 31 & 7 & 4 & 0 & 0 & 1 & 101 & 20 & 9 & 5 & 2 & 3 \\
\hline
\end{tabular}




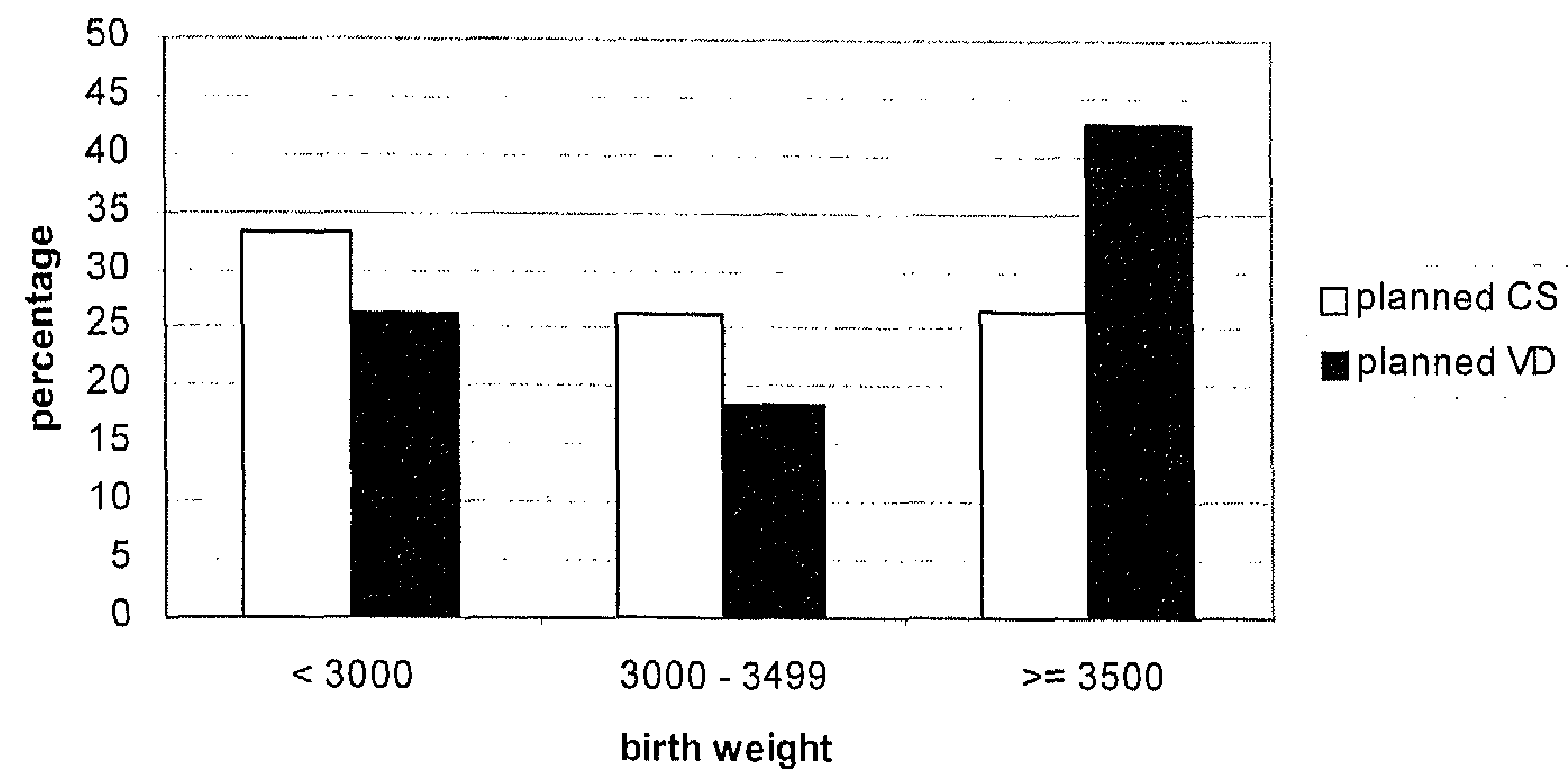

Figure 2. Percentage of children who had at least 1 abnormal domain at the ASQ at 2 years of age, subdivided by birth weight. White hars: planned CS, black bars: planned VD.

Table 3. Multivariate logistic regression analysis for 1 or more abnormal ASQ domains versus 0 abnormal ASQ domains.

\begin{tabular}{|c|c|c|}
\hline & Odds ratio & $95 \%$ Confidence interval \\
\hline \multicolumn{3}{|l|}{ Planned mode of delivery } \\
\hline Planned VD & 0.891 & $0.322-2.466$ \\
\hline Planned CS & 1 (reference calegory) & \\
\hline Birth weight* & 1.000 & $0.999-1.001$ \\
\hline \multicolumn{3}{|l|}{ Planned mode X birth weight } \\
\hline$\geq 3500 \mathrm{~g}$ and planned VD & $3.371^{\dagger}$ & $1.142-9.949$ \\
\hline$<3500 \mathrm{~g}$ or planned CS & I (reference category) & \\
\hline \multicolumn{3}{|l|}{ Maternal age } \\
\hline$<30 y$ & 0.888 & $0.410-1.924$ \\
\hline $30-34 y$ & 1 (relerence calegory) & \\
\hline$>34 \mathrm{y}$ & 0.376 & $0.122-1.162$ \\
\hline \multicolumn{3}{|l|}{ Parity } \\
\hline Nulliparous & 0.880 & $0.400-1.936$ \\
\hline Multiparous & I (reference category) & \\
\hline \multicolumn{3}{|l|}{ Type of breech } \\
\hline Frank & 1 (reference calegory) & \\
\hline Complete & 1.595 & $0.600-4.189$ \\
\hline Otherwise & 4.673 & $0.653-33.458$ \\
\hline Gestational age $\mathrm{e}^{\ddagger}$ & 0.976 & $0.933-1.021$ \\
\hline \multicolumn{3}{|l|}{ Sex } \\
\hline Male & $2.137^{\dagger}$ & $1.049-4.352$ \\
\hline Female & I (reference calegory) & \\
\hline
\end{tabular}


Multivariate logistic regression analysis indicated that there was a significant interaction between birth weight and planned mode of delivery (adjusted odds ratio [OR] for interaction term 3.37; 95\% confidence interval [CI] 1.14 to 9.95) (Table 3) and that, apart from this interaction, no effect existed of planned type of delivery (adjusted OR 0.891; $95 \% \mathrm{CI} 0.322$ to 2.466 ) or birth weight (adjusted OR $1.000 ; 95 \%$ CI 0.999 to 1.001 ). The difference in percentage of children with 1 or more abnormal domains in the ASQ between the planned CS group and the planned VD group was not statistically significant within the weight categories less than $3000 \mathrm{~g}$ (Chi-square $0.18, \mathrm{p}=0.67$ ) or 3000 to $3499 \mathrm{~g}$ (Chi-square $0.63, \mathrm{p}=0.43$ ) or within these categories combined (Chi-square 0.65 , $\mathrm{p}=0.42)$.

A total of 11 children scored abnormal at 3 or more domains. The characteristics of these children and subsequent problems are shown in Table 4. One child was born in the planned CS group (2.3\%) and the remaining $10(7.1 \%)$ in the planned VD group $(p=0.24)$. In the planned VD group, the relative risk $(R R)$ of having a child with 3 or more abnormal ASQ domains at 2 years of age was calculated to be 3.06 (95\% CI 0.40 to 23.32). In 6 pregnancies delivery was induced. All 6 emergency caesarean sections were performed because of failure to progress and none because of foetal distress. Three children were born by partial extraction for foetal distress during the second stage of delivery. Six children weighed $3500 \mathrm{~g}$ or more, and 3 children had been in the early neonatal morbidity group ( 1 serious and 2 moderate). ${ }^{11}$

Table 4. Characteristics of the children $(n=11)$ with 3 or more abnormal ASQ domains at 2 years of age.

\begin{tabular}{|c|c|c|c|c|c|c|c|c|c|}
\hline & $\begin{array}{l}\text { Gestational } \\
\text { age (wk.d) }\end{array}$ & Sex & $\begin{array}{l}\text { Type of } \\
\text { breech }\end{array}$ & $\begin{array}{c}\text { Induction } \\
\text { (YN) }\end{array}$ & $\begin{array}{l}\text { Mode } \\
\text { delivery }\end{array}$ & $\begin{array}{l}\text { Apgar } \\
\text { score } \\
\left(1^{1} / 5^{1}\right)\end{array}$ & $\begin{array}{l}\text { pH (um- } \\
\text { bilical } \\
\text { artery) }\end{array}$ & $\begin{array}{l}\text { Birth } \\
\text { weight } \\
\text { (g) }\end{array}$ & $\begin{array}{l}\text { Early neona- } \\
\text { tal morbid- } \\
\text { ity* }\end{array}$ \\
\hline 1 & 39.2 & M & Frank & $\mathrm{N}$ & Emergency CS & $2 / 5$ & 7.31 & 3440 & Moderate $^{\dagger}$ \\
\hline 2 & 40.5 & $F$ & Frank & $\mathrm{N}$ & Vaginal Birth & $7 / 9$ & 7.20 & 4430 & - \\
\hline 3 & 41.5 & M & Complete & $\mathrm{Y}$ & Emergency CS & $9 / 10$ & 7.28 & 4590 & - \\
\hline 4 & 41.2 & M & Complete & $\mathrm{N}$ & Emergency CS & $9 / 9$ & 7.31 & 4000 & - \\
\hline 5 & 41.6 & M & Frank & $\mathrm{Y}$ & Partial Extraction & $8 / 9$ & 7.25 & 3300 & - \\
\hline 6 & 38.0 & M & Frank & $\mathrm{Y}$ & Partial Extraction & $4 / 7$ & 7.16 & 3500 & Moderate $\mathrm{c}^{\ddagger}$ \\
\hline 7 & 39.2 & $\mathrm{~F}$ & Frank & Y & Emergency CS & $3 / 7$ & 7.18 & 2740 & - \\
\hline 8 & $4 J .3$ & M & Complete & $Y$ & Emergency CS & $9 / 9$ & 7.28 & 3290 & - \\
\hline 9 & 40.3 & $M$ & Frank & $\mathrm{Y}$ & Emergency CS & $8 / 10$ & 7.29 & 3120 & - \\
\hline 10 & 38.1 & $F$ & Other & $N$ & Elective CS & $8 / 9$ & 7.25 & 4160 & - \\
\hline 11 & 41.1 & $\mathrm{~F}$ & Frank & $N$ & Partial Extraction & $2 / 7$ & 7.11 & 3805 & Serious \\
\hline
\end{tabular}

CS, Caesarean section. M. Male, F, Female. *Morbidity defined as serious or moderate. ${ }^{11+}$ Hydrocephalus, Apgar score 5 after 5 minutes. ${ }^{\ddagger}$ Plexus lesion absent at discharge. ${ }^{\S}$ Plexus lesion present at discharge. 


\section{Comment}

Based on the ASQ results at 2 years of age, planned vaginal delivery is associated with an increased risk of neurodevelopmental delay at 2 years of age in term breech children with a birth weight greater than $3500 \mathrm{~g}$.

The TBT demonstrated an increase in early neonatal morbidity in the planned vaginal birth group, compared with the planned caesarean section group.' A significantly increased moderate neonatal morbidity was published before in the same cohort of nonrandomised patients as in the current study, who were allowed to deliver vaginally during the TBT study period. ${ }^{11}$

As shown in the 2-year follow-up of the TBT, no difference was found between the started vaginal delivery and the planned caesarean section. In our study we did not find a different percentage in the group with 1 or more abnormal domain according to the mode of delivery. However, children greater than $3500 \mathrm{~g}$ with planned vaginal delivery had a significantly higher risk of having 1 or more abnormal domains at the ASQ. The risk of having 1 or more abnormal ASQ domains was some $16 \%$ higher in the planned VD group than in the planned CS group. So when judging the risks or benefits of the mode of delivery for long-term neurodevelopment in breech babies, it is important to take birth weight into account. In practice, several different cut-off points for the estimated birth weight above which a primary caesarean section is indicated have been suggested, such as $3500 \mathrm{~g},{ }^{15} 3750 \mathrm{~g},{ }^{16} 3800 \mathrm{~g},{ }^{17} 4000 \mathrm{~g},{ }^{18}$ and even $4500 \mathrm{~g} .{ }^{19}$ However, foetal weight estimation, which can be performed clinically or by ultrasound, is difficult. In general, clinical evaluation of the weight of the foetus is as accurate as the sonografic method. ${ }^{20}$ Estimation of the weight of the foetus in breech position may not be as accurate as in cephalic position and the mean absolute error may be more than $12 \%{ }^{21}$ Unfortunately, in our study the estimated foetal weight was not stated routinely for all deliveries. Therefore, the difference between the estimated and the actual birth weight could not be reported.

Moreover, at 2 years of age, the non-randomised children within the planned VD group were 3 times as likely to have abnormal scores on 3 or more domains of the ASQ as compared to the children within the planned CS group (RR 3.06). Although the value of this criterion with regard to serious neurodevelopmental delay is not supported by published evidence, the RR is in agreement with the results of a meta-analysis of studies published between 1966 and 1992 of planned vaginal delivery, compared with planned caesarean section for breech presentation at term. ${ }^{2}$ This meta-analysis showed that, despite the paucity of data, long-term infant morbidity occurred more frequently among infants in the planned vaginal delivery groups, with a typical odds ratio of $2.88(95 \% \mathrm{CI}$ 1.04 to 7.97$)$. $^{2}$ The $95 \% \mathrm{CI}$ in our study, however, was much wider ( 0.40 to 23.32 ) because of relatively small numbers of patients. The number of children with 3 or more abnormal ASQ domains was too small for statistical analysis of the influence of birth weight. More studies are needed to clarify the weight issue.

There was a large difference in the percentage of children with 1 or more abnormal domains in the ASQ between our study (27.9\%) and the TBT (9.3\%). Selection bias could be a possible explanation. In the TBT, only a selected group of investigators participated in the 2-year follow-up with a response rate of $79.6 \%$, resulting in a response 
rate of only $44.3 \%$ for the whole group. ${ }^{10}$ This percentage is less than half of the response rate of $90.1 \%$ in our study. Another explanation could be, that in our study all questionnaires were completed at home and none by telephone, which is possibly less reliable.

An important limitation of this study is that we were not able to perform a neurodevelopment assessment in case of 1 or more abnormal domains in the ASQ, which is considered to be the gold standard. ${ }^{13,14}$ We realize and stress that the validity of using the ASQ as a means to report neurodevelopmental outcome is in question. The ASQ may be useful as a screening test with a negative predictive value of $98 \% .^{22}$ A positive predictive value of $40 \%$, however, stresses the point that a screening tool does not replace full and professional developmental assessment, but only helps to guide selection of those children who need further attention. Therefore, our results should be interpreted with caution.

We conclude that based on the ASQ at 2 years of age an elective caesarean section is preferred for term breech babies with a birth weight greater than $3500 \mathrm{~g}$. Estimating foetal birth weight is advised when selecting the best mode of delivery for the term breech baby. 


\section{References}

1. Hannah ME, Hannah WJ, Hewson SA, Ilodnett ED, Saigal S, Willan AR. Planned caesarean section versus planned vaginal birth for breech presentation at term: a randomised multicentre trial. Lancet 2000;356:1375-83.

2. Cheng $M$, Hannah $M$. Breech delivery at term: a critical review of the literature. Obstet Gynecol 1993;82:605-18.

3. Gifford DS, Morton SC, Fiske M, Kahn K. A meta-analysis of infant outcomes after breech delivery. Obstet Gynecol 1995;85:1047-54.

4. Committee for Quality NVOG (Dutch Society of Obstetrics and Gynaecology) Guideline 7- Breech presentation. July 2001. Utrecht.

5. Molkenboer JFM. Bouckaert PXIM, Roumen FJME, Recent trends in breech delivery in the Netherlands. BJOG 2003;110:948-51.

6. Bistoletti P, Nisell H, Palme C, Lagercrantz H. Term breech delivery: early and late complications. Acta Obstet Gynecol Scand 1981;60:165-71.

7. Svenningsen NW, Westgren M, Ingemarsson I. Modern strategy for the term breech delivery: a study with 4-ycar follow-up of the infants. J Perinat Med 1985;13:117-26.

8. Rosen MG, Debanne S, 'Thompson K, Bilenker RM. Long-term neurological morbidity in breech and vertex births. Am J Obstet Gynecol 1985;151:718-20.

9. Münstedt K, Georgi von R, Reucher S, Kygmunt M, Lang U. Term breech and long-term morbiditycesarean section versus vaginal breech delivery. Fur I Obstet Gynecol Reprod Biol 2001:96:163-7.

10. Whyte Il, Hannah MIE, Saigal S, Hannah WJ, Hewson S, Amankwah K et al. Outcomes of children at 2 years after planned cesarean versus planned vaginal delivery for breech presentation at term: the international randomized Term Breech Trial. Am J Obstet Gynecol 2004:191:864-71.

11. Molkenboer JIM Reijners EPJ, Nijhuis JG, Roumen FJME. Moderate neonatal morbidity after vaginal term breech delivery. J Matern Fetal Neonatal Med 2004;16:357-61.

12. Hannah WJ, Allardice J, Amankwah K, Baskett 'T, Cheng M, Fallis B et al. The Canadian consensus on breech management at term. I Soc Obstet Gynecol Can 1994;16:1839-58.

13. Squires J, Potter L., Bricker D, editors. 'The ASQ user's guide for the ages \& stages questionnaires: a parent-completed, child-monitoring system. Baltimore (MD): Paul H: Brookes Publishing Co; 1995.

14. Syuires 1, Bricker D, Potter 1. Revision of a parent-completed developmental screaning tool: Ages and Stages Questionnaires. J Pediatr Psychol 1907:22:313-28.

15. Schiff E, Friedman SA, Mashiach S, lart O, Barkai G, Sibai BM. Maternal and neonatal outcome of 846 term singleton breech deliveries: seven-year experience at a single center. Am I Obstet Gynecol $1996 ; 175: 18-23$.

16. Diro M, Puangsticharem A. Royer L, O'Sullivan MJ, Burkett G. Singleton term breach deliveries in nulliparous and multiparous women: a 5-year experience at the University of Miami/Jackson Memorial Hospital. Am J Obstet Gynecol 1999;181:247-52.

17. Daniel Y, Fait G, Lessing JB, Jaffa A, David MP, Kupfermine MJ. Outcome of 496 term singleton breech deliveries in a tertiary center. Am J Perinatol 1998;15:97-101.

18. Koo MR, Dekker GA, van Geijn HP. Perinatal outcome of singleton term breech deliveries. Eur J Obstet Gynecol Reprod Biol 1998;78:19-24.

19. Albrechtsen S, Rasmussen S, Reigstad H, Markestad T, Irgens LM, Dalaker K. Evaluation of a protocol for selecting fetuses in breech presentation lor vaginal delivery or cesarcan section. Am J Obstet Gynecol 1997;177:586-92.

20. O'Reilly-Gree C. Divon M. Sonographic and clinical methods in the diagnosis of macrosomia. Clin Obstet Gynecol 2000;43:309-20.

21. Chauhan SP, Magann EF, Nael RW 3rd, Martin JN Jr, Morrison JC. Sonographic assessment of birth weight among breech presentations. Ultrasound Obstet Gynecol 1995;6:54-7.

22. Skellern CY, Rogers Y, O'Callaghan MJ. A parent-completed developmental questionnaire: follow up of ex-premature infants. J Paediatr Child Health 2001;37:125-9. 


\title{
Maternal health outcomes two years after term breech delivery
}

\author{
Molkenboer JFM \\ Debie $S$ \\ Roumen FJME \\ Smits LJM \\ Nijhuis JG
}

J Matern Fetal Neonatal Med 2007;20:319-24 


\begin{abstract}
Objective: To evaluate maternal health outcomes two years after term breech delivery. Design: This was a non-randomised single-centre prospective cohort study. Mothers were asked to fill out questionnaires at two years postpartum to judge their health in the previous three to six months. Outcomes of the planned caesarean section group were compared with outcomes of the planned vaginal delivery group, whether or not a vaginal birth was realized or an emergency caesarean section was performed.

Results: One hundred and eighty-three women completed a follow-up questionnaire at two years postpartum. No differences in maternal experiences concerning breastfeeding, taking care of her child and the relationship with her partner were found between the two groups. Also, no differences were found in all investigated maternal health items, or in sexual activity or fertility.

Conclusion: Maternal health outcomes two years after term breech delivery were similar after planned caesarean section and plamned vaginal delivery.
\end{abstract}




\section{$\because \cdots 11,14$}

\section{Introduction}

The optimal route for delivering a term breech baby, with regard to both mother and child, has been the subject of debate for a long time. ' In the past, most pregnant women were encouraged to deliver vaginally since the risk of maternal mortality was higher among caesarean section births. ${ }^{2}$ A large scale randomised study, the Term Breech Trial (TBT), concluded in October 2000 that a policy of planned caesarean section was better for the foetus in breech presentation at term than a policy of planned vaginal birth. ${ }^{3}$ In that study, the risk of mortality and morbidity for the child in the planned vaginal birth group was three times as high as in the planned caesarean section birth group. ${ }^{3}$ As a result of this publication, a steep increase of caesarean sections was seen for singleton breech presentations in the Netherlands, on top of the already existing rising trend of caesarean sections. $^{4}$

The TBT studied maternal outcomes as well. At three months post partum it was found that planned caesarean delivery was associated with a lower risk of urinary incontinence. ${ }^{5}$ The results of the maternal follow-up two years after delivery revealed only a higher risk of constipation in the planned caesarean section group compared with planned vaginal birth."

Our department participated in the TBT with 35 randomised patients. During that study period the non-randomised term breech presentations were also carefully documented. Neonatal results and neurodevelopmental outcomes of the non-randomised children at two years of age have been published elsewhere. ${ }^{7,8}$ As non-randomised patients are a good reflection of daily practice, we were also interested in the health outcomes of the non-randomised term breech mothers two years after birth. Therefore, they were sent the same questionnaires as the randomised women in the TBT.

\section{Patients and methods}

From July 20, 1998 until April 21, 2000 we encountered 238 women with a term breech presentation. Thirty-five women participated in the TBT and were excluded from the present study. The remaining 203 mothers did not participate in the TBT, but consented to be analysed in the same way. ${ }^{7}$ The planned vaginal deliveries were managed according to the usual procedures in our department, which followed the guidelines of the TBT-protocol. ${ }^{3}$

Two years after delivery all mothers were asked to fill out questionnaires evaluating their health and related topics from the previous 3-6 months. These questionnaires were identical with those used in the TBT follow-up. 6.9 The questionnaires included items on duration of breast-feeding, relationship with infant and partner, subsequent pregnancies and the existence of health problems. For every health problem, all women indicated how much of a problem this had been for them. Postpartum depression was scored by use of the Edinburgh Postnatal Depression Scale (EPDS). ${ }^{10}$ All non-randomised women who returned the questionnaires were included in the analysis.

Outcomes of the planned caesarean section group were compared with outcomes of the planned vaginal delivery group, whether or not a vaginal birth was realized or an emer- 
gency caesarean section was performed. The answers from the questionnaires were documented in a structured scheme designed in Windows Excel. This information was analysed using SAS (SAS version 8.02, SAS Institute, Cary, NC, USA). The chi-square test and the Student's T-test were used to compare proportions and means, respectively. A two-sided p-value of less than 0.05 was considered statistically significant.

\section{Results}

From the 203 non-randomised participants two children were born with lethal congenital anomalies and excluded. The remaining 201 mothers decided on the planned mode of delivery with their gynaecologist. ${ }^{7}$ Eighteen mothers were lost to follow-up for various reasons: there were language-barrier problems with three mothers, four mothers had moved to an unknown address, two refused participation, two did not return the questionnaire and seven had no phone and did not respond to mail. So, two years following a breech birth, 183 women filled out questionnaires about their health in the previous 3-6 months, giving a response rate of $90.1 \%$. Forty-three women were in the planned caesarean section (CS) group and 140 women were in the planned vaginal delivery (VD) group. Figure 1 shows the study population and actual method of birth. 


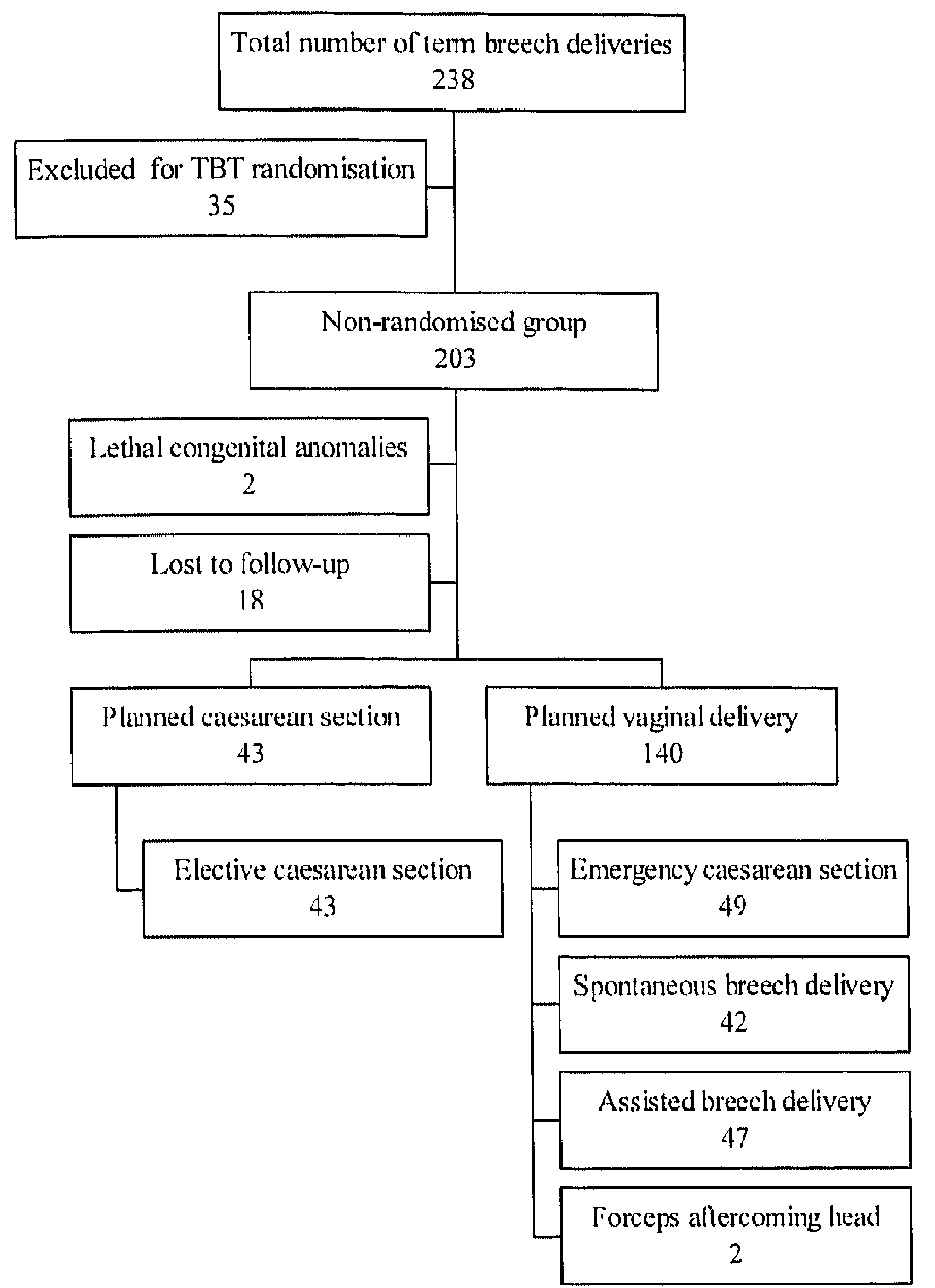

Figure 1. The non-randomised study population according to planned and actual method of delivery.

Table 1 presents the baseline characteristics of the non-randomised women. There were some differences between the planned CS group and the planned VD group, with respect to gestational age $(\mathrm{p}<0.001)$, maternal age $(\mathrm{p}=0.06)$, and type of breech presentation $(\mathrm{p}=0.05)$.

Almost all women were living with the same partner two years after the breech birth as at the time of birth, and almost all the participants completed the questionnaire by mail, most of them without help.

Table 2 presents maternal experiences concerning breastfeeding, taking care of her child, and the relationship with her partner. No differences between the groups were found. About half of the women in both groups indicated that they had breastfed with a mean duration of 3.6 months. Most mothers reported that caring for their child and motherhood was easy. The relationship with the partner was mostly happy, and better or unchanged compared with the period before birth. 
$113 ! 11+9$

Table 1. Baseline characteristics of the non-randomised women.

\begin{tabular}{|c|c|c|c|}
\hline & $\begin{array}{c}\text { Planned CS } \\
(N=43) \\
n(\%) \\
\end{array}$ & $\begin{array}{c}\text { Plammed VI) } \\
(N=14(0) \\
n(0 / 1)\end{array}$ & p-value \\
\hline \multicolumn{4}{|l|}{ Age of the mother $(y)$} \\
\hline $20-24$ & $4(9.3)$ & $6(4.3)$ & \multirow[t]{5}{*}{0.06} \\
\hline $25-29$ & $16(37.2)$ & $57(40.7)$ & \\
\hline $30-34$ & $17(39.5)$ & $56(40.0)$ & \\
\hline $35-39$ & $4(9.3)$ & $21(15.0)$ & \\
\hline$\geq 40$ & $2(4.7)$ & 0 & \\
\hline \multicolumn{4}{|l|}{ Parity } \\
\hline Nulliparous & $27(62.8)$ & $94(67.1)$ & \multirow[t]{2}{*}{0.60} \\
\hline Multiparous & $16(37.2)$ & $46(.32 .9)$ & \\
\hline \multicolumn{4}{|l|}{ Gestational age at delivery (wk) } \\
\hline $37^{0}-37^{+6}$ & $9(20.9)$ & $13(9.3)$ & \multirow[t]{5}{*}{$\because 0.001 *$} \\
\hline $38^{0}-38^{+6}$ & $24(55.8)$ & $20([4.3)$ & \\
\hline $39^{\circ}-39^{+6}$ & $6(14.0)$ & $29(20.7)$ & \\
\hline $40^{\circ}-40^{+6}$ & $1(2.3)$ & $43(30.7)$ & \\
\hline$\geq 41^{0}$ & $3(7.0)$ & $35(25.0)$ & \\
\hline \multicolumn{4}{|l|}{ Type of breech presentation } \\
\hline Frank & $37(86.0)$ & $11+(81.4)$ & \multirow[t]{3}{*}{0.05} \\
\hline Complete & $3(7.0)$ & $24(17.1)$ & \\
\hline Other & $3(7.0)$ & $2(1 .+1)$ & \\
\hline \multicolumn{4}{|l|}{ Birth weight baby $(\mathrm{g})$} \\
\hline$<2500$ & $1(2.3)$ & $+(2.9)$ & \multirow[t]{5}{*}{0.33} \\
\hline $2500-2999$ & $8(18.6)$ & $.34(2+.3)$ & \\
\hline $3000-3499$ & $19(44.2)$ & $60(+2.9)$ & \\
\hline $3500-3999$ & $8(18.6)$ & $.33(2.3,6)$ & \\
\hline$\geq 4000$ & $7(16.3)$ & $9(0.4)$ & \\
\hline $\begin{array}{l}\text { Living with same husband as when baby } \\
\text { was born }\end{array}$ & $42(100)$ & $136(90 . .31$ & 0.58 \\
\hline \multicolumn{4}{|l|}{ Method of completion of questionnaires ${ }^{\dagger}$} \\
\hline By mail & $42(97.7)$ & $128(93.4)$ & \multirow[t]{2}{*}{0.53} \\
\hline By phone/personal interview & $1(2.3)$ & $(6.6)$ & \\
\hline \multicolumn{4}{|l|}{$\begin{array}{l}\text { Help with completion of questionnaires } \\
\text { Yes }\end{array}$} \\
\hline Yes & $8(8.6)$ & $1.3(\% .4)$ & \multirow[t]{2}{*}{0.1} \\
\hline No & $35(81.4)$ & $126(90.7)$ & \\
\hline
\end{tabular}

CS caesarean section, VD vaginal delivery. *Statistically significant. ${ }^{+}$Some women did not respond to this question. 
Table 2. Experiences of the mother

\begin{tabular}{|c|c|c|c|c|c|}
\hline & \multirow{2}{*}{$\begin{array}{c}\text { Planned CS } \\
(\mathrm{N}=43) n(\%) \\
\mathrm{CS}(\mathrm{N}=43)\end{array}$} & \multicolumn{3}{|c|}{$\begin{array}{c}\text { Planned VD } \\
(\mathrm{N}=140) \cap(\%)\end{array}$} & \multirow[b]{2}{*}{ p-value } \\
\hline & & $\operatorname{CS}(N=49)$ & $\mathrm{VD}(\mathrm{N}=91)$ & Total $(\mathrm{N}=140)$ & \\
\hline \multicolumn{6}{|l|}{ Breastfeeding } \\
\hline Did breast feed* & $23(53.5)$ & $32(66.7)$ & $44(48.9)$ & $76(55.1)$ & 0.85 \\
\hline Mcan duration (months) & $3.43(\mathrm{SD}=3.1)$ & $3.87(\mathrm{SD}=3.1)$ & $3.58(\mathrm{SD}=3.2)$ & $3.70(\mathrm{SD}=3.2)$ & 0.72 \\
\hline \multicolumn{6}{|l|}{ Caring for child* } \\
\hline \multicolumn{6}{|l|}{ Ease of caring for child } \\
\hline Easy & $37(88.1)$ & $41(85.4)$ & $79(88.8)$ & $120(87.6)$ & 0.93 \\
\hline Difficult & $5(11.9)$ & $7(14.6)$ & $10(11.2)$ & $17(12.4)$ & \\
\hline \multicolumn{6}{|l|}{ Experience of motherhood } \\
\hline Easy & $35(81.4)$ & $38(79.2)$ & $79(89.2)$ & $117(86.0)$ & 0.46 \\
\hline Dillicult & $8(18.6)$ & $10(20.8)$ & $9(10.2)$ & $19(14.0)$ & \\
\hline \multicolumn{6}{|l|}{ Relationship with partner $^{\dagger}$} \\
\hline \multicolumn{6}{|l|}{ Relationship now } \\
\hline Happy & $42(97.7)$ & $47(97.9)$ & $84(94.4)$ & $131(95.6)$ & 0.54 \\
\hline Unhappy & $1(2.3)$ & $1(2.1)$ & $5(5.6)$ & $6(4.4)$ & \\
\hline \multicolumn{6}{|c|}{ Relationship compared with before child was born } \\
\hline Better/about the same & $42(97.7)$ & $44(89.8)$ & $81(90.0)$ & $125(90.6)$ & 0.13 \\
\hline Worse & $1(2.3)$ & $4(8.2)$ & $9(10.0)$ & $13(9.4)$ & \\
\hline
\end{tabular}

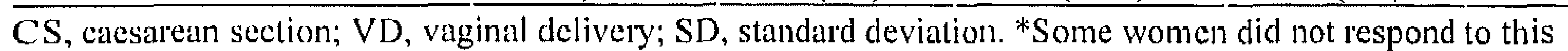
question. ${ }^{\dagger}$ Three women had no partner at that time.

Table 3 presents information on general maternal health, pain and menstrual problems. About one third of the women in both groups reported to have visited a doctor since the breech birth. Some of these visits were made in relation to pelvic problems, problems with the caesarean section wound, psychological puerperal problems or backache problems. A few of the women reported having had an operation; these included cholecystectomy, dilatation and curettage $(D \& C)$, sterilization or subsequent pregnancy with caesarean section. About half of the women in both groups reported to have had recurring pains in the last 3-6 months. The only significant difference was, that in the planned CS group women judged pain more often as 'quite a lot', whereas women in the planned VD group described it more often as 'mild' $(\mathrm{p}=0.03)$. The percentages of women with painful, irregular or heavy menstrual periods problems did not differ between the groups.

In Table 4 other maternal health problems are described. No significant differences between both groups were found in the percentages of women with complaints of urinary incontinence, faecal incontinence, incontinence of flatus, fatigue or tiredness, breast problems, constipation, headache, backache, painful perineum, haemorrhoids, difficulty or pain voiding urine, vaginal discharge, and sexual problems. However, women who had sexual problems in the planned CS group reported more often to judge this as 'a big problem', whereas most women in the planned VD group judged it as 'a little problem' $(\mathrm{p}=0.05)$. 
Table 3. Morbidity of the mother: general health, pain, and menstrual prohlems.

\begin{tabular}{|c|c|c|c|c|c|}
\hline & \multirow{2}{*}{$\begin{array}{c}\text { Planned CS } \\
(\mathrm{N}=43) \cap(\%) \\
\mathrm{CS}(\mathrm{N}=43)\end{array}$} & \multicolumn{3}{|c|}{$\begin{array}{l}\text { Plamned VI) } \\
(\mathrm{N}=140) \cap(\%) \\
\end{array}$} & \multirow[b]{2}{*}{ p-value } \\
\hline & & $C S(N=49)$ & $V I D(N=91)$ & Total $(N=-140)$ & \\
\hline \multicolumn{6}{|l|}{ Health } \\
\hline Visited doctor since birth baby ${ }^{\dagger}$ & $14(32.6)$ & $13(26.5)$ & $25(28.1)$ & $38(27.5)$ & 0.53 \\
\hline Admitted to hospital & $2(4.7)$ & $3(6.1)$ & $4(4.5)$ & $7(5.1)$ & 0.86 \\
\hline Had an operation & $1(2.3)$ & $4(8.2)$ & $4(4.5)$ & $8(5.8)$ & 0.3 \\
\hline \multicolumn{6}{|l|}{ Pain } \\
\hline Experienced pain in last 3-6 months & $24(55.8)$ & $26(53.1)$ & $47(51.6)$ & $7.3(52.1)$ & 0.67 \\
\hline Backache & $14(32.5)$ & $11(22.4)$ & $27(29.7)$ & $38(27.1)$ & 0.52 \\
\hline Headache & $4(9.3)$ & $7(14.3)$ & $13(14.3)$ & $20(14.3)$ & 0.56 \\
\hline Outside of abdomen or front & $5(11.6)$ & $S(10.2)$ & $1(1.1)$ & $6(4.3)$ & 0.09 \\
\hline Deep inside abdomen or front & $7(16.3)$ & $5(10.2)$ & $12(13.2)$ & $17(12.1)$ & 0.47 \\
\hline In bottom or genital area & $4(9.3)$ & $2(4.7)$ & $9(9.9)$ & $11(7.9)$ & 0.7 \\
\hline Other ${ }^{\ddagger}$ & $7(16.3)$ & $8(18.6)$ & $14(15.4)$ & $22(15.7)$ & 0.82 \\
\hline Worst pain experienced ${ }^{\dagger}$ & $N=24$ & $N=25$ & $N=46$ & $N=71$ & \\
\hline Mild pain & $7(29.2)$ & $15(60.0)$ & $24(52.1)$ & $39(5+.9)$ & $0.03 *$ \\
\hline Quite a lot of pain & $16(66.7)$ & $8(32.0)$ & $17(37.0)$ & $25(35.2)$ & \\
\hline Severe pain & $1(4.2)$ & $2(8,0)$ & $5(10.9)$ & $7(9.9)$ & \\
\hline Took medicine for pain & $14(58.3)$ & $14(53.8)$ & $23(48.9)$ & $.37(50.7)$ & 0.55 \\
\hline Menstrual problems & $N=37$ & $N=37$ & $N=82$ & $N=119$ & \\
\hline Painful menstrual periods & $14(37.8)$ & $16(43.2)$ & $20(24.4)$ & $.36(30.3)$ & 0.39 \\
\hline No problem & $3(21.4)$ & $2(12.5)$ & $5(16.7)$ & $7(19.4)$ & 0.68 \\
\hline A litle problem & $10(71.4)$ & $11(68.8)$ & $12(60.0)$ & $23(6.3 .9)$ & \\
\hline A big problem & $1(7.1)$ & $3(18.9)$ & $3(15.0)$ & $6(16.7)$ & \\
\hline Irregular menstrual periods ${ }^{\dagger}$ & $8(22.9)$ & $4(10.8)$ & $11(1.3 .4)$ & $15(14.3)$ & 0.24 \\
\hline No problem & $4(50.0)$ & $2(50.0)$ & $3(33.3)$ & $5(38.5)$ & 0.87 \\
\hline A little problem & $3(37.5)$ & $2(50.0)$ & $4(44.4)$ & $6(46.2)$ & \\
\hline A big problem & $1(12.5)$ & 0 & $2(22.2)$ & $2(15.4)$ & \\
\hline Heavy menstrual periods ${ }^{t}$ & $7(21.1)$ & $8(21.6)$ & $22(26.8)$ & $30(28.9)$ & 0.39 \\
\hline No problem & 0 & $2(28.6)$ & $8(36.4)$ & $10(34.5)$ & 0.14 \\
\hline A little problem & $6(85.7)$ & $4(57.1)$ & $10(45.5)$ & $14(48.3)$ & \\
\hline A big problem & $1(14.3)$ & $1(14.3)$ & $4(18.2)$ & $5(17.2)$ & \\
\hline
\end{tabular}

CS, caesarean section; VD, vaginal delivery. *Statistically signiticant, Some women did not respond to this question. ${ }^{\ddagger}$ Examples: pain in the pelvis, Sl-joint or in a leg. "s Twenty-seven women were not menstruating ( 6 in planned CS group, 21 in planned VD group). 
Table 4. Morbidity of the mother: other health problems.

\begin{tabular}{|c|c|c|c|c|c|}
\hline & \multirow{2}{*}{$\begin{array}{c}\text { Planned CS } \\
(N=43) \text { n }(\%) \\
\operatorname{CS}(N=43)\end{array}$} & \multicolumn{3}{|c|}{$\begin{array}{l}\text { Planned VD } \\
(\mathrm{N}=140) \mathrm{n}(\%)\end{array}$} & \multirow[b]{2}{*}{$\mathrm{p}$-value } \\
\hline & & $\mathrm{CS}(\mathrm{N}=49)$ & $\operatorname{VD}(N=91)$ & Total $(N=140)$ & \\
\hline Urinary incontinence $^{\dagger}$ & $15(34.9)$ & $14(29.2)$ & $28(30.8)$ & $42(30.2)$ & 0.56 \\
\hline No problem & $7(46.7)$ & $8(57.1)$ & $15(53.6)$ & $23(54.8)$ & 0.40 \\
\hline A little problem & $8(53.3)$ & $5(35.7)$ & $11(39.2)$ & $16(38.1)$ & \\
\hline A big problem & 0 & $1(7.1)$ & $2(7.1)$ & $3(7.14)$ & \\
\hline Faecal incontinence & $1(2.3)$ & $3(6.1)$ & $6(6.7)$ & $9(6.5)$ & 0.30 \\
\hline No problem & 0 & $1(33.3)$ & 0 & $1(11.1)$ & 0.73 \\
\hline A little problem & $1(100)$ & $2(66.7)$ & $6(100)$ & $8(88.9)$ & \\
\hline A big problem & 0 & 0 & 0 & 0 & \\
\hline Incontinence of tlatus ${ }^{\dagger}$ & $1.3(30.2)$ & $16(32.7)$ & $24(27.0)$ & $40(29.0)$ & 0.88 \\
\hline No problem & $10(76.9)$ & $10(62.5)$ & $15(62.5)$ & $25(62.5)$ & 0.59 \\
\hline A little problem & $3(23.8)$ & $5(31.2)$ & $9(37.5)$ & $14(35.0)$ & \\
\hline A big problem & 0 & $1(6.3)$ & 0 & $1(2.5)$ & \\
\hline Fatigue/tiredness ${ }^{\dagger}$ & $34(79.1)$ & $37(77.1)$ & $65(71.4)$ & $102(73.4)$ & 0.45 \\
\hline No problem & $2(5.9)$ & $2(5.4)$ & $11(16.9)$ & $13(12.8)$ & 0.48 \\
\hline A little problem & $23(67.7)$ & $24(64.9)$ & $36(55.4)$ & $60(58.8)$ & \\
\hline$A$ big problem & $9(20.5)$ & $11(29.7)$ & $18(27.7)$ & $29(28.4)$ & \\
\hline Breast probiens ${ }^{\dagger}$ & $6(14.0)$ & $5(10.4)$ & $7(7.7)$ & $12(8.6)$ & 0.31 \\
\hline No problem & 0 & 0 & $3(42.9)$ & $3(25.0)$ & 0.17 \\
\hline A little problem & $5(83.3)$ & $5(100)$ & $4(57.1)$ & $9(75.0)$ & \\
\hline A big problem & $1(16.7)$ & 0 & 0 & 0 & \\
\hline Constipation $^{\dagger}$ & $11(25.9)$ & $12(25.0)$ & $11(12.1)$ & $23(16.6)$ & 0.18 \\
\hline No problem & 0 & $2(16.7)$ & $4(36.4)$ & $6(26.1)$ & 0.14 \\
\hline A little problem & $8(72.7)$ & $7(58.3)$ & $7(63.6)$ & $14(60.9)$ & \\
\hline$\Lambda$ big problem & $3(27.3)$ & $3(25.0)$ & 0 & $3(13.1)$ & \\
\hline Headache ${ }^{\dagger}$ & $23(56.1)$ & $26(54.2)$ & $45(49.5)$ & $71(51.1)$ & 0.57 \\
\hline No problem & $7(30.4)$ & $2(7.7)$ & $10(22.2)$ & $12(16.9)$ & 0.25 \\
\hline A little problem & $11(47.8)$ & $20(76.9)$ & $27(60.0)$ & $47(66.2)$ & \\
\hline A big problem & $5(21.7)$ & $4(15.4)$ & $8(17.8)$ & $12(16.9)$ & \\
\hline Backalche ${ }^{\dagger}$ & $25(58.1)$ & $26(54.2)$ & $43(49.5)$ & $69(49.6)$ & 0.33 \\
\hline No problem & $2(8.0)$ & $3(11.5)$ & $3(7.0)$ & $6(8.7)$ & 0.24 \\
\hline A litlle problem & $12(48.0)$ & $19(73.1)$ & $26(60.5)$ & $45(65.2)$ & \\
\hline A big problem & $11(44.0)$ & $4(15.4)$ & $14(32.6)$ & $18(26.1)$ & \\
\hline Painful perineum ${ }^{\dagger}$ & $3(7.0)$ & $4(8.3)$ & $15(16.5)$ & $19(13.7)$ & 0.24 \\
\hline No problem & 0 & $1(25.0)$ & $1(6.7)$ & $2(10.5)$ & 0.68 \\
\hline A little problem & $2(60.7)$ & $1(25.0)$ & $13(86.7)$ & $14(73.7)$ & \\
\hline A big problem & $1(33.3)$ & $2(50.0)$ & $1(6.7)$ & $3(15.8)$ & \\
\hline Haemorthoids" & $12(27.9)$ & $15(30.6)$ & $31(34.4)$ & $46(33.1)$ & 0.52 \\
\hline No problem & $3(25.0)$ & $6(42.9)$ & $12(40.0)$ & $18(40.9)$ & 0.56 \\
\hline A little problem & $6(50.0)$ & $5(35.7)$ & $14(46.7)$ & $19(43.2)$ & \\
\hline A big problem & $3(25.0)$ & $3(21.4)$ & $4(13.3)$ & $7(15.9)$ & \\
\hline Difficulty or pain voiding urine & $3(7.0)$ & $4(8.2)$ & $4(4.4)$ & $8(5.7)$ & 0.76 \\
\hline No problem & 0 & 0 & 0 & 0 & 0.39 \\
\hline A little problem & $1(33.3)$ & $2(50,0)$ & $3(75.0)$ & $5(62.5)$ & \\
\hline A big problem & $2(66.7)$ & $2(50.0)$ & $1(25.0)$ & $3(37.5)$ & \\
\hline Vaginal discharge $^{\dagger}$ & $15(34.9)$ & $24(49.0)$ & $47(51.6)$ & $71(50.7)$ & 0.07 \\
\hline No problem & $9(60.0)$ & $12(50.0)$ & $21(45.7)$ & $33(47.1)$ & 0.52 \\
\hline A little problem & $5(33.3)$ & $8(33.3)$ & $17(37.0)$ & $25(35.7)$ & \\
\hline A big problem & $1(6.7)$ & $4(16.7)$ & $8(17.4)$ & $12(17.1)$ & \\
\hline Sexual problems ${ }^{\dagger}$ & $7(16.3)$ & $9(18.4)$ & $11(12.2)$ & $20(14.4)$ & 0.76 \\
\hline No problem & $1(14.3)$ & 0 & 0 & 0 & $0.05^{*}$ \\
\hline A little problem & $1(14.3)$ & $6(66.7)$ & $6(54.5)$ & $12(60.0)$ & \\
\hline A big problem & $5(71.4)$ & $3(33.3)$ & $5(45.5)$ & $8(40.0)$ & \\
\hline Postparlum depression (>12 EPDS) & $8(18.6)$ & $10(20.4)$ & $15(16.5)$ & $25(17.9)$ & 0.91 \\
\hline
\end{tabular}

CS, cresarean section; VD, vaginal delivery; EPDS Edinburgh postnatal depression scale.

* Statistically significant. ${ }^{\dagger}$ Some did not respond to this question. 
Table 5 provides information on sexuality and subsequent pregnancies after breech birth. Nearly all women in both groups reported having had sex in the previous $3-6$ months. Nearly $17 \%$ of women in both groups experienced pain during sex, but in most cases it was indicated as 'almost not painful' or 'mildly painful'. In both groups most women were happy with their sexual relations. About one-third of the women in both groups reported a new pregnancy since the breech birth. A repeat caesarean section was performed in all $(n=3)$ women in the planned CS group, and in only $8.3 \%$ of women in the planned VD group $(n=2)(p=0.0002)$.

Table 5. Sexual activity and fertility

\begin{tabular}{|c|c|c|c|c|c|}
\hline & \multirow{2}{*}{$\begin{array}{c}\text { Planned CS } \\
(\mathrm{N}=43) \cap(\%) \\
\mathrm{CS}(\mathrm{N}=43)\end{array}$} & \multicolumn{3}{|c|}{$\begin{array}{l}\text { Plamned VD } \\
(N=14(0) n(\%)\end{array}$} & \multirow[b]{2}{*}{ p-value } \\
\hline & & $\operatorname{CS}(N=49)$ & $V D(N=91)$ & Total $(N=140)$ & \\
\hline \multicolumn{6}{|l|}{ Sexuality } \\
\hline Had sex in last 3-6 months ${ }^{\dagger}$ & $42(97.7)$ & $44(91.7)$ & $86(94.5)$ & $130(93.5)$ & 0.3 \\
\hline Had pain during sex ${ }^{\dagger}$ & $7(16.7)$ & $8(18.2)$ & $14(16.3)$ & $22(16.9)$ & 0.96 \\
\hline Almost no pain/mild pain & $5(71.4)$ & $6(75.0)$ & $11(78.6)$ & $17(77,3)$ & 0.75 \\
\hline Quite a lot/severe pain & $2(28.6)$ & $2(25.0)$ & $3(21,4)$ & $5(22.7)$ & \\
\hline \multicolumn{6}{|l|}{ Happiness with sexual relations ${ }^{\dagger}$} \\
\hline Happy & $32(84.2)$ & $31(86.1)$ & $63(86.3)$ & $9+(86.2)$ & 0.76 \\
\hline Unhappy & $6(15.8)$ & $5(13.9)$ & $10(1.3 .7)$ & $15(1.3 .8)$ & \\
\hline \multicolumn{6}{|l|}{ Pregnancies } \\
\hline $\begin{array}{l}\text { Had been pregnant after breech } \\
\text { birtl or pregnant now }\end{array}$ & $14(32.6)$ & $2 !(43.8)$ & $21(23.3)$ & $42(30,4)$ & 0.8 \\
\hline \multicolumn{6}{|l|}{ Number of pregnancies since birth } \\
\hline One & $11(84.6)$ & $11(57.9)$ & $16(88.9)$ & $27(73.0)$ & 0.4 \\
\hline More & $2(15.4)$ & $8(42.1)$ & $2(11.1)$ & $10(27.0)$ & \\
\hline \multicolumn{6}{|l|}{ Number of births since breech birth } \\
\hline One & $3(100)$ & $11(91.7)$ & $12(100)$ & $23(95.8)$ & 0.72 \\
\hline More & 0 & $1(8.3)$ & 0 & $1(4.2)$ & \\
\hline $\begin{array}{l}\text { Caesarean for one or more inlants } \\
\text { born after breech birth }\end{array}$ & $3(100)$ & $2(16.7)$ & 0 & $2(8.3)$ & $0.0002 *$ \\
\hline
\end{tabular}

CS, caesarean section; VD, vaginal delivery. *Stalistically significant. Some women did not respond to this question. 


\section{Discussion}

The TBT was a large randomised study with inherent important results. ${ }^{3,5.6,11}$ In our study we were interested in the results of the non-randomised patients during the same study period, as they are more a reflection of normal daily practice. Two groups were considered; one comprised the women who underwent an elective CS for medical or obstetric reasons or on request (planned CS), the other comprised women who were allowed to start a vaginal birth or who were in labour (planned VD). ${ }^{7}$

No differences in maternal experiences concerning breastfeeding, taking care of her child and the relationship with her partner were found between the two groups. The mean duration of breast feeding (3.6 months) was lower than in the TBT ( 8.0 months). ${ }^{6}$ Also no differences were found in all maternal health items investigated. In contrast with the TBT, the risk of constipation was equal in both groups. Women in the planned VD group judged any experienced pain during the last 3-6 months more often as mild. A reason for this is not clear; an explanation could be the fact that these women had experienced the intensity of labour pain. The few women with sexual problems in the planned CS group judged this more often as a big problem. Unfortunately, no additional specific questions on this item were asked, so it remains unclear whether these problems were pre-existent or more a reflection of feelings of insufficiency from not having experienced vaginal delivery. Also no differences in sexual activity or fertility were found. A systematic review on the literature reported inconsistent associations between caesarean delivery and sexual function. ${ }^{12}$

In summary, maternal health outcomes two years after term breech delivery were similar after planned caesarean section and planned vaginal delivery. 


\section{References}

1. Haheim L, Albrechtsen S, Berge L. Bordahl PE, Egeland T, Henriksen T, Oian P. Breech birth at term: vaginal delivery or cesarean section? A systematic review of the literature by a Norwegian revicw team. Acta Obstet Gynecol Scand 2004;83:126-30.

2. Schuitemaker N, van Roosmalen J, Dekker G, van Dongen P, van Geijn H, Bennebroek Gravenhorst J. Maternal mortality after cesarean section in The Netherlands. Acta Obstet Gynecol Scand 1997;76:3324.

3. Hannah ME, Hannah WJ, Hewson S, Hodnett E, Saigal S, Willan AR. Planned caesarean section versus planned vaginal birth for breech presentation at term: a randomised multicentre trial. Lancet 2000;356:1375-83.

4. Molkenbocr JFM, Bouckaert PXIM, Roumen FJME. Recent trends in breech delivery in the Netherlands. B.JOG 2003;110:948-51.

5. Hannah ME, Hannah WJ, Hodnell E, Chalmers B, Kung R, Willan A et al. Outcomes at 3 months after planned caesarean versus planned vaginal delivery for breech presentation at term: the international Term Breech Trial, JAMA 2002;287:1822-31.

6. Hannah ME, Whyte H, Walter J, Hewson S, Amankwah K, Cheng M et al. Maternal outcomes at 2 years after planned cesarean section versus planned vaginal birth for breech presentation at term: the international Term Breech Trial. Am J Obstet Gynecol 2004;191:917-27.

7. Molkenboer JFM, Reijners EPJ, Nijhuis JG, Roumen FIME. Moderate neonatal morbidity after vaginal term breech delivery. J Matern Fetal Neonatal Med 2004;16:357-61.

8. Molkenboer JFM, Roumen FJME, Smits LJM, Nijhuis JG. Birth weight and neurodevelopmental outcome of children at 2 years of age after planned vaginal delivery for breech presentation at term. Am J Obstet Gynecol 2006;194:624-9.

9. Maternal, Infant, and Reproductive Ilealth Research Unit. 2-year postparlum questionnaire. Available at: http://www.utoronto.ca/miru/brecch/2year. Accessed December 8, 2004.

10. Cox JL, Holden JM, Sagovsky R. Detection of postnatal depression: Development of the 10-item Edinburgh Postnatal Depression Scale. Br J Psychiatry 1987;150:782-6.

11. Hodnett ED, Hannah ME, Hewson S, Whyte H, Amankwah $\mathrm{K}$, Cheng $\mathrm{M}$ et al. Mothers' views of their childbirth experiences 2 years after planned cacsarean versus planned vaginal birth for breech presentation at term, in the international randomized 'Term Breech Trial. J Obstet Gyntecol Can 2005;27:224-31.

12. Hicks TL, Goodall SF, Quattrone EM, Lydon-Rochelle MT. Post partum sexual functioning and method of delivery: summary of the evidence. J Midwifery Womens Health 2004;49:430-6. 


\title{
Mothers' views of their childbirth experience two years after term breech delivery
}

\author{
Molkenboer JFM \\ Debie $S$ \\ Roumen FJME \\ Smits LJM \\ Nijhuis JG
}

J Psychosom Obstet Gynaecol 2007; Jul 19:1-6 [Epub ahead of print] 


\begin{abstract}
Introduction: This study was performed to evaluate mothers' views of their childbirth experience two years after term breech delivery.

Methods: Two years after delivery mothers were asked to fill out a questionnaire concerning their breech birth experience and their view about the care provided to them while giving birth. Outcomes of the planned caesarean section (CS) group were compared with outcomes of the planned vaginal delivery (VD) group, whether or not a vaginal birth was realized or an emergency caesarean section was performed. Any differences were further analysed by use of logistic regression, controlling for potential confounders.

Results: Significantly more women in the planned CS group were reassured about their baby's health $(67.4 \%$ vs. $37.9 \%, p=0.0006)$ at the time of delivery, whereas more women in the planned VD group recalled having been worried about their baby's health at the time of delivery $(45.0 \%$ vs. $25.6 \%, p=0.02)$. Also, more women in the planned VD group experienced more pain during labour and delivery than expected $(46.9 \%$ vs. $18.5 \%, p=0.008)$. In the planned VD group fewer women indicated they had an active say in decision-making $(59.1 \%$ vs. $85.3 \%, \mathrm{p}=0.001)$.

Conclusions: Evaluation of the mothers' views of their childbirth experience two years after term breech delivery showed that more women in the planned VD group recalled having been worried about their child's health at the time of delivery, experienced more pain than expected, and reported less involvement in decision-making.
\end{abstract}




\section{Introduction}

The question how to deliver a term breech baby optimally, regarding mother and child, has been subject of debate for a long time. ${ }^{1}$ In the past, most pregnant women were encouraged to deliver vaginally since the risk of maternal mortality was higher among caesarean section births. ${ }^{2}$ A large scale randomised study, the Term Breech Trial (TBT), concluded in October 2000 that a policy of planned caesarean section was better for the foetus in breech presentation at term than a policy of planned vaginal birth. ${ }^{3}$ In that study, the risk of mortality and morbidity for the child in the planned vaginal birth group was three times as high as in the planned caesarean section birth group. ${ }^{3}$ As a result of this publication, a steep increase of caesarean sections was seen for singleton breech presentations in the Netherlands, on top of the already existing rising trend of caesarean sections. ${ }^{4}$

The TBT evaluated mothers' views of their childbirth experience two years after delivery. It was concluded that planned mode of delivery influences aspects of women's evaluations of their childbirth experiences but doesn't affect evaluations of the quality of intrapartum care, support from care providers, or amount of involvement in decisionmaking. ${ }^{5}$

The department of Obstetrics and Gynaecology of the Atrium Medical Center Parkstad Heerlen participated in the TBT with 35 randomised patients. During that study period also the non-randomised term breech presentations were carefully documented. Neonatal results and neurodevelopmental outcomes of the non-randomised children at two years of age have been published elsewhere. ${ }^{6,7}$ As non-randomised patients are a good reflection of daily practice, we were also interested in the views of the childbirth experiences of the non-randomised term breech mothers two years after birth.

\section{Patients and methods}

From July 20, 1998 until April 21, 2000 we encountered 238 women with a term breech presentation. Thirty-five women participated in the TBT and were excluded from the present study. The remaining 203 mothers did not participate in the TBT, but decided with their gynaecologist about the planned mode of delivery. All women consented to be analysed in the same way. The planned vaginal deliveries were managed according to the usual procedures in our department, which followed the guidelines of the TBTprotocol. ${ }^{3}$ Two years after delivery, all mothers were asked to fill out a questionnaire about their likes and dislikes concerning the childbirth experiences and their view about the care provided to them while giving birth. This questionnaire was identical to the one used in the TBT with an explaining letter to disregard the questions concerning the TBT $^{5,8}$ The questionnaire had been translated into Dutch by two of the authors and checked for accuracy by means of retranslation into English by the 2-year follow-up research group in Toronto. All non-randomised women who returned the questionnaire were included in the analysis. Outcomes of the planned caesarean section group were compared with outcomes of the planned vaginal delivery group, whether or not a vaginal birth was realized or an emergency caesarean section was performed. The answers 
from the questionnaires were documented in a structured scheme designed in Windows Excel. This information was analyzed using SAS (SAS version 8.02, SAS Institute, Cary, NC). The chi-square test and the Student's T-test were used to compare proportions and means, respectively. Multivariate logistic regression analysis was used to check whether any statistically significant differences in proportions were attributable to confounding by associated risk factors. Variables included as potential confounders were birth weight of the infant, maternal age, parity, type of breech presentation, gestational age, and sex of the baby. A two-sided p-value of less than 0.05 was considered statistically significant.

\section{Results}

From the 203 non-randomised participants two children were born with lethal congenital anomalies and excluded. The planned mode of delivery of the remaining 201 mothers is shown in Table 1. Most women (58.2\%) were informed about the TBT by their gynaecologist during the study period. Eighteen mothers were lost to follow up for various reasons. Three mothers had a language barrier, four mothers had moved to an unknown address, two refused participation, two did not return the questionnaire and seven had no phone nor responded to mail. So, after two years 183 women filled out a questionnaire about their likes and dislikes concerning the childbirth experience, yielding a follow up of $90.1 \%$. Forty-three women were in the planned caesarean section (CS) group and 140 women were in the planned vaginal delivery (VD) group. Figure 1 shows the study population and actual method of birth.

Table 1. Reasons for non-randomisation in the TBT of pregnant women with a term breech baby.

\begin{tabular}{lcccc}
\hline & Primary CS-group & Started VB-group & Total & Percentage \\
\hline Information given about the TBT & 27 & 90 & 117 & $58.2 \%$ \\
Prefers vaginal delivery & 3 & 77 & 80 & $39.8 \%$ \\
Prefers caesarean scction & 22 & 0 & 22 & $10.9 \%$ \\
No answer & 2 & 13 & 15 & $7.5 \%$ \\
No information given about the TBT & 21 & 63 & 84 & $41.8 \%$ \\
Not eligible & 18 & 3 & 21 & $10.5 \%$ \\
Forgotten to ask & 3 & 30 & 33 & $16.4 \%$ \\
Unknown breech & 0 & 30 & 30 & $14.9 \%$ \\
Total & 48 & 153 & 201 & $100.0 \%$ \\
\hline
\end{tabular}




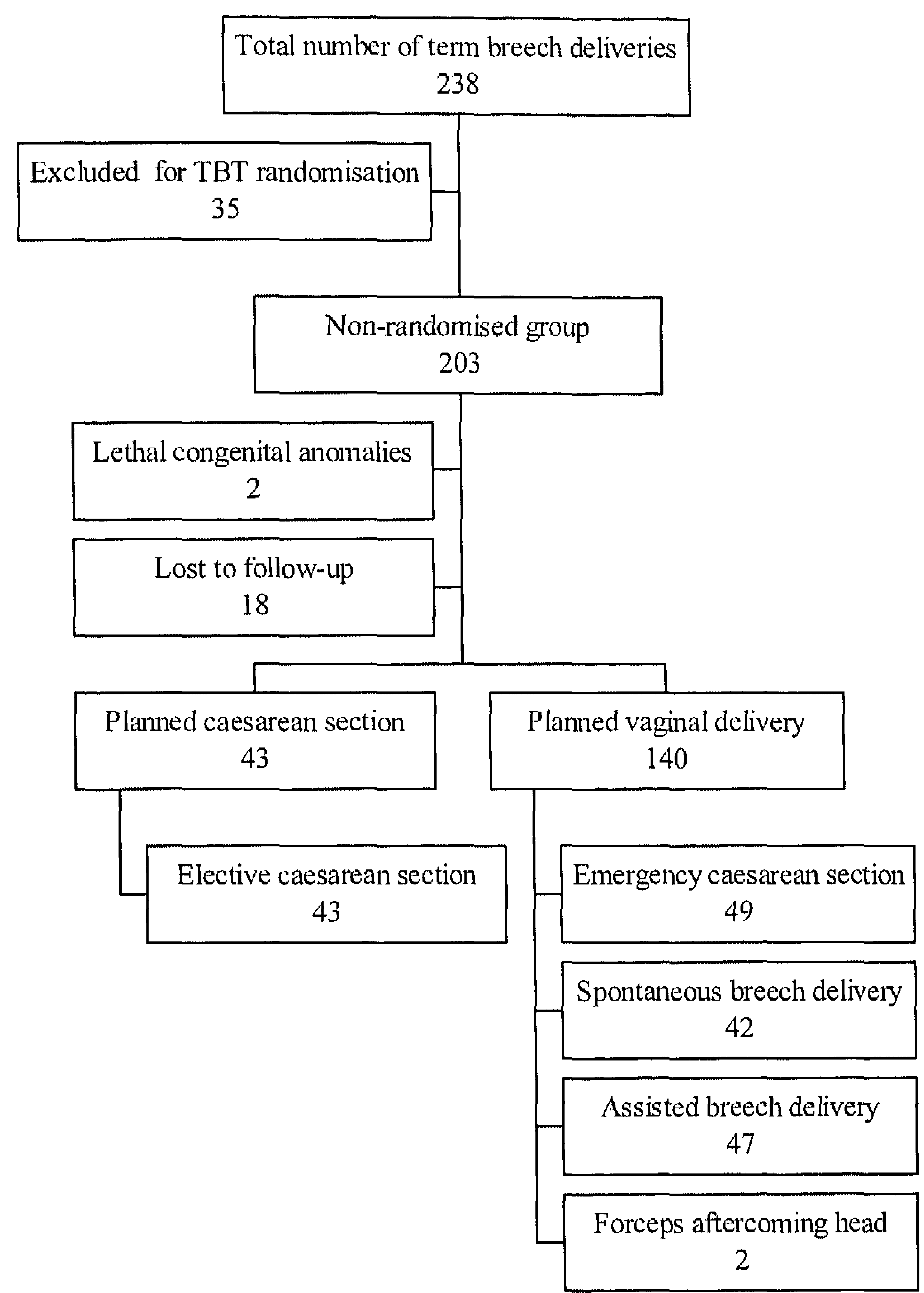

Figure 1. The non-randomised study population according to planned and actual method of delivery. 


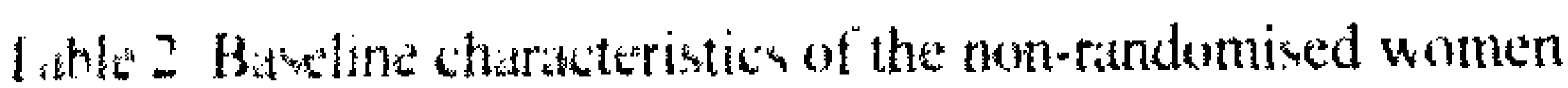

\begin{tabular}{|c|c|c|c|}
\hline & $\begin{array}{l}\text { Planned CS n }(\%) \\
\qquad N=43 \\
\end{array}$ & $\begin{array}{l}\text { Planned VD n (\%) } \\
\qquad N=140 \\
\end{array}$ & $p^{\text {-value }}$ \\
\hline \multicolumn{4}{|l|}{ Aye as the mother 8} \\
\hline 20.24 & $4(9.3)$ & $6(4.3)$ & 0.06 \\
\hline $35-24$ & $16(37.2)$ & $57(40.7)$ & \\
\hline 30.34 & $17(34.5\}$ & $56(40.0)$ & \\
\hline 35.34 & $4(9.3)$ & $21(15.0)$ & \\
\hline$\therefore 40$ & $2(4.7)$ & $0(0.0)$ & \\
\hline \multicolumn{4}{|l|}{ Parts } \\
\hline Mualliparcus & $27(62.8)$ & $94(67.1)$ & 0.60 \\
\hline Multiparous & $16(37.2)$ & $46(32.9)$ & \\
\hline \multicolumn{4}{|l|}{ (atstatioflal age de delivery (wh) } \\
\hline $37^{n} \times 37^{* 4}$ & $9(20.9)$ & $13(9.3)$ & $<0.01011^{*}$ \\
\hline $3 x^{4}-3 x^{n}$ & $24(55.8)$ & $20(14.3)$ & \\
\hline $34^{61} \cdot 39^{1+1}$ & $6(14.0)$ & $29(20.7)$ & \\
\hline $40^{61}-40$ & $1(2.3)$ & $43(30.7)$ & \\
\hline $2^{n} 41^{1 !}$ & $3(7.0)$ & $35(25.0)$ & \\
\hline \multicolumn{4}{|l|}{ I p po of breech presentution } \\
\hline Frank & $37(86.0)$ & $114(81.4)$ & 0.05 \\
\hline Complet: & $3(7.0)$ & $24(17.1)$ & \\
\hline Wher & $3(7.0)$ & $2(1.4)$ & \\
\hline \multicolumn{4}{|l|}{ Hirth weight hahy (g) } \\
\hline $25(4)$ & $1(2.3)$ & $4(2.9)$ & 0.33 \\
\hline 25090.2444 & $8(18.6)$ & $34(24.3)$ & \\
\hline $3(1) 0)-3494$ & $19(44.2)$ & $60(42.9)$ & \\
\hline $350(1)-3944$ & $8(18.6)$ & $33(23.6)$ & \\
\hline$\geq 4000$ & $7(16.3)$ & $9(6.4)$ & \\
\hline $\begin{array}{l}\text { Living with same husband as when baby } \\
\text { wats burn }\end{array}$ & $42(100)$ & $136(99.3)$ & 0.58 \\
\hline \multicolumn{4}{|l|}{ Method of completion of questionnaires ${ }^{+}$} \\
\hline By mail & $42(97.7)$ & $128(93.4)$ & 0.53 \\
\hline By phone/personal interview & $1(2.3)$ & $9(6.6)$ & \\
\hline \multicolumn{4}{|l|}{ Help with cumpletion of questionnaires } \\
\hline Yes & $8(18.6)$ & $13(9.4)$ & 0.1 \\
\hline No & $35(81.4)$ & $126(90.7)$ & \\
\hline
\end{tabular}

CS. caesarean section: VD, vaginal delivery. * Statistically signifieant. 'Some women did not respond to this quevition.

Table 3 shows the likes and dislikes of the women about the different aspects of their childbirth experience. More women in the planned VD group liked having experienced labour ( $p<0.0001$ ), liked that childbirth was natural ( $p<0.0001$ ), and liked actively participating in the birth $(\mathrm{p}=0.0003$ ), whereas they more frequently disliked that childbirth experience was very painful ( $\mathrm{p} \times 0.0001)$, and felt worried about the health of their baby at the time of delivery $(p=0.02)$. In the planned CS group, significantly more women felt reassured about their baby's health at the time of delivery $(p=0.0006)$. In the evaluation of the method of delivery, the concern about their own health, and the recovery after delivery no significant differences were found. 
the breech birth, as experienced by the mothers.

\begin{tabular}{|c|c|c|c|}
\hline & $\begin{array}{l}\text { Planned CS n (\%) } \\
\qquad N=43\end{array}$ & $\begin{array}{l}\text { Planned VD n (\%) } \\
\quad \mathrm{N}=140 \\
\end{array}$ & p-value \\
\hline -ienced labour & $5(11.6)$ & $95(67.9)$ & $<0.0001^{*}$ \\
\hline xperienced labour & $10(23.3)$ & 0 & $<0.0001 *$ \\
\hline th was natural & 0 & $73(52.1)$ & $<0.0001^{*}$ \\
\hline th experience was not very & $10(23.3)$ & $26(18.6)$ & 0.59 \\
\hline schedule the delivery & $11(25.6)$ & $4(2.9)$ & $<0.0001^{*}$ \\
\hline elivery & $18(41.9)$ & $57(40.7)$ & 0.89 \\
\hline Licipating in the birth & $8(18.6)$ & $70(50.0)$ & $0.0003^{*}$ \\
\hline ut own health & $15(34.9)$ & $61(43.6)$ & 0.31 \\
\hline ut baby's health & $29(67.4)$ & $53(37.9)$ & $0.0006^{*}$ \\
\hline$y$ was not difficult & $12(27.9)$ & $52(37.1)$ & 0.27 \\
\hline \multirow[t]{2}{*}{ ut childbirth experience } & $4(9.3)$ & $23(16.4)$ & 0.25 \\
\hline & $8(18.6)$ & $21(15.0)$ & 0.57 \\
\hline xperienced labour & $2(4.7)$ & $20(14.3)$ & 0.09 \\
\hline having experienced labour & $5(11.0)$ & $1(0.7)$ & $0.0004^{*}$ \\
\hline Ibirth experience was very & 0 & $43(30.7)$ & $<0.0001^{*}$ \\
\hline Ibirth was not natural & $15(34.9)$ & $28(20.0)$ & $0.04^{*}$ \\
\hline od of delivery & $10(23.3)$ & $30(21.4)$ & 0.8 \\
\hline ely participating in birth & $11(25.6)$ & $22(15.7)$ & 0.14 \\
\hline rering with planned method of & $3(7.0)$ & $27(19.3)$ & 0.07 \\
\hline it own health & $7(16.3)$ & $11(7.9)$ & 0.1 \\
\hline It baby's health & $11(25.6)$ & $63(45.0)$ & $0.02 *$ \\
\hline vering was difficult & $15(34.9)$ & $34(24.3)$ & 0.17 \\
\hline \multirow[t]{2}{*}{ about childbirth experience } & $9(20.9)$ & $20(14.3)$ & 0.3 \\
\hline & $8(18.6)$ & $39(27.9)$ & 0.22 \\
\hline
\end{tabular}

$\mathrm{m} ; \mathrm{VD}$, vaginal delivery. ${ }^{*}$ Statistically significant. ${ }^{\dagger}$ Examples: liked a quick delivery, - perform a caesarcan section, good information in advance.

being alone on recovery, disliked not knowing about brecch, disliked not delivering at

rizes the evaluation of care during the breech delivery, as experienced by e quality of care during delivery was judged as good or very good by ts was the helpfulness of nurses, midwives and doctors. No differences ween the two groups. There was, however, a significant difference beups in the active say in decision-making, given to the women $(\mathrm{p}=0.001)$. 1 the planned CS group reported to have had an active say in most or all almost one quarter of the women in the planned VD group reported to tive say at all. Only six women in this group indicated not to have wanted Pain experienced during labour and delivery was reported as 'more than ignificantly more women in the planned VD group $(\mathrm{p}=0.008)$. Pain exng the first weeks after delivery was not different between the two 
Table 4. Evaluation of care during brcech birth, as experienced by the mothers.

\begin{tabular}{|c|c|c|c|}
\hline & $\begin{array}{c}\text { Planned CS n (\%) } \\
\quad \mathrm{N}=43\end{array}$ & $\begin{array}{c}\text { Planned VD } n(\%) \\
\quad \mathrm{N}=140\end{array}$ & p-value \\
\hline \multicolumn{4}{|l|}{ Quality of care during delivery } \\
\hline Very good & $13(30.2)$ & $48(34.3)$ & 0.72 \\
\hline Good & $27(62.8)$ & $74(52.9)$ & \\
\hline Mixed & $2(4.7)$ & $12(8.6)$ & \\
\hline Poor & $1(2.3)$ & $4(2.9)$ & \\
\hline Very poor & 0 & $2(1.4)$ & \\
\hline \multicolumn{4}{|c|}{ Was given an active say in decision-making ${ }^{\dagger \ddagger}$} \\
\hline Yes in all cases & $18(52.9)$ & $26(22.6)$ & $0.001^{*}$ \\
\hline Yes in most cases & $11(32.4)$ & $42(36.5)$ & \\
\hline Only sometimes & $4(11.8)$ & $13(11.3)$ & \\
\hline No not at all & $1(2.9)$ & $34(29.6)$ & \\
\hline \multicolumn{4}{|c|}{ Helpfulness of the nurses or midwives ${ }^{\dagger \S}$} \\
\hline Very/täirly helpful & $37(88.1)$ & $127(92.0)$ & 0.43 \\
\hline Somewhat/only a little helpful & $5(11.9)$ & $11(8.0)$ & \\
\hline \multicolumn{4}{|l|}{ Helpfulness of doctors ${ }^{\dagger p}$} \\
\hline Very/fairly helpful & $35(81.4)$ & $106(76.3)$ & 0.48 \\
\hline Somewhat/only a little helpful & $8(18.6)$ & $33(23.7)$ & \\
\hline \multicolumn{4}{|c|}{ Pain experienced during labour and deliveryll } \\
\hline Less than/as expected & $22(81.5)$ & $51(53.1)$ & $0.008^{*}$ \\
\hline More than expected & $5(18.5)$ & $45(46.9)$ & \\
\hline \multicolumn{4}{|c|}{ Pain experienced during first wecks after delivery"l } \\
\hline Less than/as expected & $14(42.4)$ & $61(56.5)$ & 0.16 \\
\hline More than expected & $19(57.6)$ & $47(43.5)$ & \\
\hline
\end{tabular}

CS, caesarean section; VD, vaginal delivery. ${ }^{*}$ Statistically significant. ${ }^{\top}$ Some women did not respond to this question. 'Six women indicated they had not wanled an active say, and 27 women said they did not know. ${ }^{8}$ Two women had no nurses or midwives present. Three women indicated that their doctors were not helpful at all. "Some women said they had not known what to expect.

We carried out multiple logistic regression analysis on four outcomes that were statistically significantly different between the two intervention groups: felt reassured about baby's health, felt worried about baby's health, felt was given active say in decisionmaking, and experienced more pain than expected during delivery. As shown in Table 5 , the associations tended to become somewhat more pronounced after adjustment.

Table 5. Comparison of outcomes in planned caesarean section (CS) group versus planned vaginal delivery (VD) group.

\begin{tabular}{|c|c|c|c|c|}
\hline Outcome & $\begin{array}{c}\text { Planned CS } \\
n(\%) \\
N=43\end{array}$ & $\begin{array}{c}\text { Planned VD } \\
n(\%) \\
N=140\end{array}$ & $\begin{array}{l}\text { Unadjusted RR } \\
\qquad(95 \% \mathrm{Cl})\end{array}$ & $\begin{array}{l}\text { Adjusted OR } \\
(95 \% \mathrm{CI})\end{array}$ \\
\hline Felt reassured about baby's health & $29(67.4)$ & $53(37.9)$ & $3.40(1.65-7.01)$ & $3.86(1.64-9.06)$ \\
\hline Felt worried about baby's health & $11(25.6)$ & $63(45.0)$ & $0.42(0.20-0.90)$ & $0.36(0.15-0.91)$ \\
\hline $\begin{array}{l}\text { Felt had active say (yes in all or } \\
\text { most cases) }\end{array}$ & $29(85.3)$ & $68(59.1)$ & $4.01(1.45-11.11)$ & $5.79(1.71-19.60)$ \\
\hline More pain during delivery than & $5(18.5)$ & $45(46.9)$ & $0.26(0.09-0.74)$ & $0.21(0.06-0.70)$ \\
\hline
\end{tabular}

Models adjusted for birth weight, maternal age, parity, type of breech presentation, gestational age, and sex of the baby. 


\section{Discussion}

The TBT was a large randomised study with inherent important results., ${ }^{3,59,10}$ In our study we were interested in the results of the non-randomised patients during the same study period, as they are more a reflection of normal daily practice. Two groups were discerned, one who underwent an elective CS for medical or obstetric reasons or on request, the other who was allowed to start vaginal birth or who were in labour. Because the choice between elective CS or planned VD may be determined by factors that might also influence the way mothers perceive their delivery, we controlled for several maternal and foetal characteristics that potentially influence obstetric decision-making. The associations did not dilute after adjustment for these factors, which strengthens our confidence that the observed effects were not attributable to prior prognostic differences between treatment groups (Table 5).

Though many questions were suggestive to the method of delivery, it is remarkable that there was a significant difference in the way women think about their baby's health. Significantly more women in the planned VD group felt worried about the health of their baby at the time of delivery, in contrast with the women in the planned CS group, who were more often reassured about their baby's health. This is in line with the followup study of the TBT which also found an association between women in the planned CS group and less worry about their baby's health. ${ }^{5}$ It must be stressed, that these results may be influenced by the fact that the mothers were familiar with the neonatal results of the TBT at the moment they filled in the questionnaire, which was two years after its publication and after extensive discussion in the Netherlands. ${ }^{4}$ During that period Dutch media emphasized the increased neonatal risk of vaginal term breech delivery. Another important finding was, that one third of the women in the planned VD group disliked that childbirth experience was very painful. This can be explained partly by the fact that during the study period no pain relief with epidurals was offered to women with vaginal breech deliveries because of fear that the parturient would not be able to push effectively during the second stage of labour. Almost half of them experienced more pain during labour and delivery than expected. In that group, 44 women reported that they had no idea what to expect. This could be due to the fact that two-third of both groups had never given birth before and so did not know what to expect.

The TBT concluded that the method of delivery had no influence on evaluation of quality of care, support from care providers or amount of involvement in decision-making by the mothers. ${ }^{5}$ However, we found a significant difference in the amount of reported involvement in decision-making. This is known to be an important dimension of childbirth satisfaction. " One quarter of all women in the planned VD group indicated they had no active say in decision-making, whereas only 2.3 percent of women in the planned CS group shared that view. Apparently some women did not like to deliver vaginally for fear of the child's health or amount of pain during delivery, but they probably had not been able to propagate this opinion. As a result they might have had the impression they were not taken seriously. This finding could also be due to the fact that during the study period, which was before publication of the TBT results, it was standard policy to deliver breeches vaginally in the Netherlands without real consultation with the pregnant woman. Again, at the time the questionnaire was filled in, most 
(H:H)!

women were familiar with and influenced by the TBT results and by the discussions in the media.

We conclude that more women with a planned VD were worried about the health of their baby at the time of delivery, experienced more pain than expected, and reported less involvement in decision-making. 


\section{References}

1. Haheim L, Albrechtsen S, Berge L. Bordahl PE, Egeland T, Henriksen T, Oian P. Breech birth at term: vaginal delivery or cesarean section? A systematic review of the literature by a Norwegian review team. Acta Obstet Gynecol Scand 2004;83:126-30.

2. Schuitemaker N, van Roosmalen J, Dekker G, van Dongen P, van Geijn H, Bennebroek Gravenhorst J. Maternal mortality after cesarean section in The Netherlands. Acta Obstet Gynecol Scand 1997;76:3324.

3. Hannah ME, Hannah WJ, Hewson S, Hodnett E, Saigal S, Willan AR. Planned caesarean section versus planned vaginal birth for breech presentation at term: a randomised multicentre trial. Lancet 2000;356:1375-83.

4. Molkenboer JFM, Bouckaert PXJM, Roumen FJME. Recent trends in breech delivery in the Netherlands. BJOG 2003;1 10:948-51.

5. Hodnett ED, Hannah ME, Hewson S, Whyte H, Amankwah K, Cheng M et al. Mothers' views of their childbirth experiences 2 years after planned caesarean versus planned vaginal birth for breech presentation at term, in the international randonized Term Breech Trial. J Obstet Gynaecol Can 2005;27:224-31.

6. Molkenboer JFM, Reijners EPJ, Nijhuis JG, Roumen FJME. Moderate neonatal morbidity after vaginal term breech delivery. J Matern Fetal Neonatal Med 2004;16:357-61.

7. Molkenboer JFM, Roumen FJME, Smits LJM, Nijhuis JG. Birth weight and neurodevelopmental outcome of children at 2 years of age after planned vaginal delivery for breech presentation at term. Am J Obstet Gynecol 2006;194:624-9.

8. Maternal, Infant, and Reproductive Health Research Unit. 2-year postpartum questionnaire. Available at: http://www.utoronto.ca/miru/breech/2year. Accessed December 8, 2004.

9. Hannah ME, Hannah WJ, Hodnett E, Chalmers B, Kung R, Willan A et al. Outcomes at 3 months after planned caesarean versus planned vaginal delivery for breech presentation at term: the international Term Breech Trial. JAMA 2002;287:1822-31.

10. Hannah ME, Whyte H, Walter J, Hewson S, Amankwah K, Cheng $M$ et al. Maternal outcome at 2 years after planned cesarean section versus planned vaginal birth for breech presentation at term: the international Term Breech Trial. Am J Obstet Gynecol 2004;191:917-27.

11. Hodnett ED. Pain and women's satisfaction with the experience of childbirth: a systematic review. Am J Obstet Gynecol 2002;186:160-72. 
Conservative management in breech deliveries leads to similar results compared with cephalic deliveries

\author{
Molkenboer JFM \\ Vencken PMLH \\ Sonnemans LGJ \\ Roumen FJME \\ Smits $F$ \\ Buitendijk SE \\ Nijhuis JG
}




\begin{abstract}
Objective: To compare the difference in neonatal mortality and morbidity between breech and cephalic presentations at term.

Methods: This was a retrospective matched cohort study in two centres between July 1998 and April 2000, including all breech deliveries between $37+0$ and $41+6$ weeks, except cases with multiple gestations and antepartum intra-uterine deaths. All breech presentations were matched with two cephalic presentations. Onset of labour and route of delivery were recorded, and neonatal data were categorised into variables belonging to serious morbidity or moderate morbidity.

Results: One thousand one hundred and nineteen deliveries were included. Three hundred and seventy-three babies were in breech position and 746 in cephalic position. The gestational age and birth weight of the babies in the breech group were lower than in the cephalic group $(\mathrm{p}<0.001)$. Congenital abnormalities occurred more often in the breech group $(p<0.005)$. An elective caesarean section was performed in $23.3 \%$ of breech presentations versus $3.5 \%$ of cephalic presentations $(p<0.001)$. Emergency caesarean sections were done in $29.2 \%$ of breech presentations versus $8.8 \%$ of cephalic presentations $(p<0.001)$. Children born in breech presentation had lower Apgar scores after 1 minute $(p<0.0001)$, but 5 -minute Apgar scores were the same in both groups $(p=0.22)$. Children born in breech received significantly more resuscitation than children born in cephalic presentation $(\mathrm{p}<0.001)$. In both groups no perinatal mortality occurred. No differences were observed in percentages of children with serious or moderate neonatal morbidity between the breech and cephalic lies.

Conclusions: Although the numbers are small, this study shows that the conservative (vaginal) approach in selected foetuses in breech position can be safely pursued with neonatal results similar to foetuses in cephalic presentation.
\end{abstract}




\section{Introduction}

The foetal breech position occurs in 3 to $4 \%$ of all term deliveries. ${ }^{1}$ During many years the route of delivery for this group was controversial, until the large randomised trial of Hannah et al. showed that an elective caesarean section appeared to be safer for the foetus than an attempt to deliver vaginally. ${ }^{2}$ In the Netherlands, where about $50 \%$ of all breech presentations used to be delivered vaginally, the Term Breech Trial (TBT) had great impact. More than $80 \%$ of the breeches are now delivered by caesarean section, of which $60 \%$ are elective caesarean sections. ${ }^{3}$

The outcome of the TBT can also lead to the question as to what the outcome would be if a similar study protocol were followed for term foetuses in cephalic position. In a recent article the potential consequences, and the effect this might have on obstetric practice, were discussed. ${ }^{4}$ Several studies assessed the differences in mortality and morbidity for children born in breech position compared to children born in cephalic position. ${ }^{5-7}$ It remains unclear, however, whether the differences in mortality and morbidity are related to the position of the foetus or to the mode of delivery. Some studies have shown a difference in neonatal mortality and morbidity in relation to the method of delivery of a breech and a cephalic group, others did not find this association. ${ }^{5-7}$

The purpose of this study was to investigate whether a difference exists in mortality and morbidity between children born in breech and in cephalic presentation during a time period in which elective caesarean sections were not carried out routinely in breech lies.

\section{Methods}

From July 1998 until April 2000, in two adjacent hospitals (Atrium Medical Centre in Heerlen and University Hospital in Maastricht), data were collected from all breech deliveries between $37+0$ weeks and $41+6$ weeks' gestation. As all deliveries during this period were included, no power analysis was performed. Breech presentations from multiple gestations and antepartum intra-uterine deaths were excluded. Every child born in breech position was matched with a child born in cephalic position before and after this birth, to make the control group twice as large as the case group. The cephalic and breech births were matched for gestational age and parity. Data were obtained from the medical records of the gynaecologist. If the paediatrician was consulted during or after delivery, the baby's medical file was also checked for missing data.

For all patients a number of basic characteristics of the mother and the delivery were recorded. These included age of the mother, gestational age, presentation of the foetus (breech or cephalic), beginning of the delivery, induction (yes or no), reason for induction, method of stimulation, anaesthesia, perineal trauma and method of birth. A number of data of the newborn were also recorded, including birth trauma. The data were subdivided into variables belonging to serious neonatal morbidity or moderate neonatal morbidity. The variables related to the serious neonatal morbidity were the same as used in the study of Hannah et al: birth trauma, which included subdural haematoma, intracerebral or intraventricular haemorrhage, spinal cord injury, basal skull fracture, peripheralnerve injury present at discharge from hospital, or clinically significant genital injury; 
seizures occurring within 24 hours after birth; Apgar score of less than 4 at 5 minutes; umbilical artery $\mathrm{pH}$ lower than 7.00; base deficit of at least 15 ; hypotonia of at least 2 hours; stupor, decreased response to pain or coma; intubation and ventilation for at least 24 hours; tube feeding for 4 days or more; or admission to the neonatal intensive care unit (NICU) for longer than 4 days. ${ }^{2}$ Moderate neonatal morbidity was defined as: peripheral-nerve injury at birth but absent at discharge from hospital; a 5-minute Apgar score of 4-6; an umbilical artery $\mathrm{pH}$ between 7.00 and 7.10, or a base deficit between 10 and 15; hypotonia not longer than two hours; intubation and ventilation with a maximum of 24 hours; tube feeding during two to four days; or admission to the NICU during two to four days. ${ }^{8}$

All variables were analysed with SPSS (Chi-square test, Fisher's exact test, independent samples t-test and the Wilcoxon test). A two-sided p-value of $<0.05$ was considered significant.

\section{Results}

Of a total of 391 breech deliveries, eighteen were excluded. In one patient the foetus was diagnosed to be in cephalic position during labour instead of breech position. Three patients were excluded because of an antepartum intra-uterine foetal death not related to the position, and one because of a twin pregnancy. Thirteen patients were excluded because their gestational age was not within the range of the selection criteria. Hence, 373 babies in breech position were matched with 746 babies in cephalic position, making a total of 1119 deliveries studied.

Table 1 shows the baseline characteristics of both groups. The age of the mother was not significantly different between the two groups $(p=0.17)$. The gestational age at delivery was lower in the breech group: 39.4 weeks versus 39.6 weeks $(p<0.001)$. Most breech babies were delivered at $<40$ weeks of gestation, and most cephalic babies at $\geq$ 40 weeks of gestation. The percentage of elective caesarean sections in the breech delivery group $(23.3 \%)$ was significantly higher than in the cephalic group $(3.5 \%$; $\mathrm{p}<0.001)$, and the percentage of inductions significantly lower $(7.6 \%$ vs. $19.9 \%$, $p<0.001)$. Accordingly, the percentage of spontaneous onset of labour was lowest in the breech group (69.4\% vs. $76.7 \%, \mathrm{p}<0.001$ ). Also the mode of delivery was significantly different. In the breech group more extractions, although not significant, were performed $(26.4 \%$ vs. $20.8 \%, p=0.11)$, and more emergency caesarean sections $(29.2 \%$ vs. $8.8 \%, \mathrm{p}<0.001)$. Table 1 also shows that significantly more breech babies were female $(p<0.05)$. A congenital abnormality was present in $6.2 \%$ of the breech presentations, compared to $2.5 \%$ in the cephalic group ( $\mathrm{p}<0.005$ ).

The birth weight was lower in the breech group, as compared to the cephalic group $(\mathrm{p}<0.0001$; Table 2). Children born in breech presentation had lower Apgar scores after 1 minute $(5.1 \%$ vs. $0.9 \%, \mathrm{p}<0.0001)$ and received significantly more resuscitation $(\mathrm{p}<0.001)$.

No perinatal mortality occurred in either group (Table 3). A total of 21 children in the breech group had one or more items of serious neonatal morbidity. Sixteen of them had only one item, five children had two or more items. In the cephalic group 26 children 
had one or more items of serious neonatal morbidity. Fifteen of them had only one item and 11 children had two or more items.

Table 1. Baseline characteristics of the breech and cephalic group.

\begin{tabular}{|c|c|c|c|}
\hline Total $\mathrm{N}=1119$ & $\begin{array}{c}\text { Breech group } \\
\mathrm{N}=373\end{array}$ & $\begin{array}{c}\text { Cephalic group } \\
N=746\end{array}$ & p-value \\
\hline \multicolumn{4}{|l|}{ Age mother (years) } \\
\hline$\leq 19$ & $2(0.5)$ & $14(1.9)$ & 0.055 \\
\hline $20-24$ & $23(6.2)$ & $70(9.4)$ & \\
\hline $25-29$ & $129(34.6)$ & $251(33.6)$ & \\
\hline $30-34$ & $164(44.0)$ & $284(38.1)$ & \\
\hline$\geq 35$ & $55(14.7)$ & $127(17.0)$ & \\
\hline Mean ( \pm SD) & $30.4(4.1)$ & $30.1(4.7)$ & 0.17 \\
\hline \multicolumn{4}{|l|}{ Gestational age (weeks)* } \\
\hline $37^{0 / 7}$ to $37^{6 / 7}$ & $38(10.2)$ & $60(8.1)$ & $<0.001$ \\
\hline $38^{0 / 7}$ to $38^{6 / 7}$ & $84(22.6)$ & $118(15.9)$ & \\
\hline $39^{0 / 7}$ to $39^{6 / 7}$ & $94(25.3)$ & $165(22.2)$ & \\
\hline $40^{0 / 7}$ to $40^{6 / 7}$ & $90(24.2)$ & $222(29.8)$ & \\
\hline $41^{1 / 7}$ to $41^{6 / 7}$ & $66(17.7)$ & $179(24.1)$ & \\
\hline Mean $( \pm \mathrm{SD})$ & $39.4(8.9)$ & $39.6(8.8)$ & $<0.001$ \\
\hline \multirow[t]{3}{*}{ Position } & Complete breech 289 (77.5) & $\mathrm{OA}^{\dagger}$ position $697(93.4)$ & \\
\hline & Frank breech $70(18.8)$ & $\mathrm{OP}^{\ddagger}$ position $28(3.8)$ & \\
\hline & Incomplete breech 14 (3.8) & Cephalic others $21(2.8)$ & \\
\hline \multicolumn{4}{|l|}{ Start of labour } \\
\hline Elective CS & $86(23.3)$ & $26(3.5)$ & $<0.001$ \\
\hline Spontaneous & $259(69.4)$ & $572(76.7)$ & $<0.001$ \\
\hline Induction & $28(7.6)$ & $148(19.9)$ & $<0.001$ \\
\hline \multicolumn{4}{|l|}{ Mode of delivery } \\
\hline Spontaneous & & $490(65.7)$ & \\
\hline Shoulder dystocia & & $16(2.1)$ & \\
\hline Bracht & $85(22.8)$ & & \\
\hline Partial extraction & $91(25.8)$ & & \\
\hline Forcipal extraction & $2(0.6)^{8}$ & $55(7.4)$ & \\
\hline Ventouse extraction & & $100(13.4)$ & \\
\hline $\begin{array}{l}\text { Emergency CS, } \\
\text { Indication: }\end{array}$ & $109(29.2)$ & $59(8.8)$ & $<0.001$ \\
\hline Not stated & 5 & 0 & \\
\hline Failure to progress & 75 & 33 & \\
\hline Fetal distress & 28 & 16 & \\
\hline Combination & 0 & 7 & \\
\hline Maternal indication & 1 & 3 & \\
\hline Gender & & & $<0.05$ \\
\hline Male & $160(42.9)$ & $392(52.5)$ & \\
\hline Female & $213(57.1)$ & $354(47.5)$ & \\
\hline Congenital abnormality & $23(6.2)$ & $19(2.5)$ & $<0.005$ \\
\hline
\end{tabular}

Data are expressed as $n(\%)$, except where otherwise indicated. SI), standard deviation; CS, caesarean section. ${ }^{*}$ Three missing. ${ }^{\dagger}$ Occiput Anterior. ${ }^{\ddagger}$ Occiput Posterior. ${ }^{8}$ Aftercoming head. 
CHADMR:

Table 2. Characteristics of the newborns in the breech and cephalic group.

\begin{tabular}{|c|c|c|c|}
\hline Total $N=1119$ & $\begin{array}{c}\text { Breech group } \\
\mathrm{N}=373\end{array}$ & $\begin{array}{c}\text { Cephalic group } \\
N=746\end{array}$ & p-valu \\
\hline Birth weight (g) & & & $<0.000$ \\
\hline$<2500$ & $23(6.2)$ & $35(4.7)$ & \\
\hline $2500-2999$ & $93(24.9)$ & $122(16.4)$ & \\
\hline $3000-3499$ & $152(40.8)$ & $292(39.2)$ & \\
\hline $3500-3999$ & $87(23.3)$ & $212(28.5)$ & \\
\hline $4000-4499$ & $16(4.3)$ & $72(9.7)$ & \\
\hline$\geq 4500$ & $2(0.5)$ & $12(1.6)$ & \\
\hline Mean $( \pm S D)$ & $3219(478)$ & $3372(509)$ & $<0.000$ \\
\hline 1-min Apgar score & & & $<0.000$ \\
\hline $0-3$ & $19(5.1)$ & $7(0.9)$ & \\
\hline $4-6$ & $34(9.1)$ & $45(6,0)$ & \\
\hline $7-10$ & $319(85.8)$ & $694(93.0)$ & \\
\hline 5-min Apgar score & & & 0.223 \\
\hline $0-4$ & $1(0.3)$ & 0 & \\
\hline $4-6$ & $6(1.6)$ & $7(0.9)$ & \\
\hline $7-10$ & $365(98.1)$ & $739(99.1)$ & \\
\hline Umbilical artery $\mathrm{pH}(\mathrm{SD})^{*}$ & & & 0.436 \\
\hline$<7.00$ & $7(1.9)$ & $10(1.4)$ & \\
\hline $7.00-7.10$ & $26(7.2)$ & $67(9.2)$ & \\
\hline$>7.10$ & $329(90.9)$ & $655(89.5)$ & \\
\hline Mean $( \pm S D)$ & $7.22(0,09)$ & $7.22(0,09)$ & 0.95 \\
\hline Umbilical vein $\mathrm{pH}(\mathrm{SD})^{\dagger}$ & & & 0.522 \\
\hline$<7.00$ & $1(0.3)$ & $7(1.0)$ & \\
\hline $7.00 \cdot 7.10$ & $5(1.5)$ & $11(1.5)$ & \\
\hline$>7.10$ & $319(98.2)$ & $702(97.5)$ & \\
\hline Mean $( \pm S D)$ & $7.29(0,08)$ & $7.29(0,08)$ & 0.89 \\
\hline \multicolumn{4}{|l|}{ Resuscitation } \\
\hline No & $304(81.5)$ & $685(91.8)$ & $<0.001$ \\
\hline Only $\mathrm{O}_{2}$ & $31(8.3)$ & $44(5.9)$ & $<0.001$ \\
\hline $\mathrm{O}_{2}$, mask and balloon & $38(10.2)$ & $17(2.3)$ & $<0.001$ \\
\hline
\end{tabular}

Data are expressed as $\mathrm{n}(\%)$, except where otherwise indicated. SD, standard deviation.

*25 items missing. ${ }^{\dagger} 74$ items missing. 
A total of 55 children in the breech group had one or more items of moderate neonatal morbidity. Thirty-seven of them had only one item and 18 children had two or more items.

In the cephalic group 113 children had one or more items of moderate neonatal morbidity. Seventy-eight had only one item and 35 children had two or more items.

After combining the serious and moderate neonatal morbidity groups, there were nine children in the breech group and eight children in the cephalic group who had items in both the serious and the moderate morbidity group. So, no differences in total percentages of children with serious or moderate perinatal morbidity were observed between breech and cephalic presentations (Table 3).

Table 3. Serious and moderate neonatal morbidity in the breech and cephalic group.

\begin{tabular}{|c|c|c|c|}
\hline Total $N=1119$ & $\begin{array}{c}\text { Breech group } \\
\quad N=373 \\
\end{array}$ & $\begin{array}{c}\text { Cephalic group } \\
N=746 \\
\end{array}$ & $\mathrm{p}$-value \\
\hline \multicolumn{4}{|l|}{ Serious neonatal morbidity } \\
\hline Birth trauma & $5(1.3)$ & 0 & \\
\hline Convulsions $<24 \mathrm{~h}$ & $1(0.3)$ & 0 & \\
\hline 5 min Apgar score $<4$ & $1(0.3)$ & 0 & \\
\hline Umbilical artery $\mathrm{pH}<7.00$ & $7(1.9)$ & $10(1.3)$ & \\
\hline Base deficit $\geq 15$ & $8(2.1)$ & $15(2.0)$ & \\
\hline Hypotonia $\geq 2 \mathrm{~h}$ & $3(0.8)$ & $4(0.5)$ & \\
\hline Intubation $\geq 24 \mathrm{~h}$ & 0 & $2(0.3)$ & \\
\hline Tube feeding $>4$ days & $1(0.3)$ & $1(0.1)$ & \\
\hline $\mathrm{NICU}>4$ days & $4(1.1)$ & $5(0.7)$ & \\
\hline Subtotal number of children & $21(5.6)$ & $26(3.5)$ & 0.09 \\
\hline \multicolumn{4}{|l|}{ Moderate neonatal morbidity } \\
\hline Nerve damage, absent at discharge & $1(0.3)$ & 0 & \\
\hline 5 min Apgar score 4-6 & $6(1.6)$ & $7(0.9)$ & \\
\hline Umbilical artery pH 7.00 7.10 & $26(7.0)$ & $67(9.0)$ & \\
\hline Base deficit $10-15$ & $3 !(4.2)$ & $70(9.4)$ & \\
\hline Hypotonia $<2 \mathrm{~h}$ & $5(1.3)$ & $1(0.1)$ & \\
\hline Intubation $<24 \mathrm{~h}$ & $6(1.6)$ & 0 & \\
\hline Tube feeding 2-4 days & $2(0.5)$ & $2(0.3)$ & \\
\hline NICU 2-4 days & $2(0.5)$ & $1(0.1)$ & \\
\hline Subtotal number of children & $55(14.7)$ & $113(15.0)$ & 0.86 \\
\hline Total number of children & $67(18.0)$ & $131(17.6)$ & 0.87 \\
\hline
\end{tabular}

Data are expressed as $n(\%)$, except where otherwise indicated.

NICU, neonatal intensive care unit.

\section{Discussion}

Conflicting data have been published concerning the issue whether there is a difference in neonatal mortality and morbidity between babies in breech and cephalic position related to the way of delivery. ${ }^{5-7}$ Therefore, we compared the outcome of a cohort of term breech deliveries with matched term cephalic deliveries to see whether there was a difference in mortality and morbidity, related to the mode of delivery. This was done to see whether there is any indication that the 'Dutch conservative management' of breech 
deliveries (i.e. before the Term Breech Trial was published) could be hazardous to the foetus as compared with the foetus in cephalic position.

In the breech presentation group, most babies were delivered at $<40$ weeks of gestation, presumably caused by the higher number of elective caesarean sections. In this group, fewer women were induced, whereas more babies were delivered by emergency caesarean section and vaginal extraction. The percentage of children with congenital abnormalities was higher in the breech presentation group, which is in line with percentages in other studies." Birth weight was significantly less in the breech group, which might be explained by the lower gestational age and the higher percentage of females in this group.

The higher percentage of babies with low 1-minute Apgar scores and resuscitation in the breech group might be explained by the higher number of caesarean sections and vaginal extractions in this group, and the fact that a paediatrician was almost always present when a child was born in breech presentation.

However, no differences were observed in 5-minute Apgar scores and arterial and venous $\mathrm{pH}$ between both groups. Moreover, no differences in perinatal mortality and morbidity were found between the groups: neonatal mortality did not occur in either group, and serious or moderate perinatal morbidity was not significantly different. Of course, this may be due to the relatively small numbers included, and a weakness in this study is the fact that no power analysis was performed. On the other hand, this study indicates that a high number needed to treat would be necessary and therefore a change in clinical management can not really be advocated.

One of the conclusions could be that Dutch obstetricians were capable of selecting those breech deliveries in which a trial of vaginal delivery can safely be pursued and were able to create neonatal results similar to the cephalic position with very moderate rates of planned caesarean sections.

On the other hand, it remained unclear whether the neonatal results in both groups were optimal. Perinatal mortality in the Netherlands is relatively high, when compared to the other countries in the European Union..$^{10}$ Moreover, increasing the caesarean section rate in the term breech in the Netherlands resulted in a significant decrease of neonatal mortality and short term morbidity. "Therefore, it may well be the case that the neonatal outcome for children in cephalic position would also improve with a more 'aggressive' management.

However, a randomised controlled trial similar to the TBT, for children in cephalic position, would need massive numbers with inherent increased maternal complications on the short term and the long term due to the higher percentage of caesarean sections. ${ }^{12-15}$

At present, performing such a study seems unethical until more research has been performed on the long term effects of higher numbers of elective caesarean sections. 


\section{References}

1. Hickok DE, Gordon DC, Milberg JA, Williams MA, Daling JR. The lirequency of breech presentation by gestational age at birth: a large population-based study. Am J Obstel Gynecol 1992;166:851-2.

2. Hannah ME, Hannah WJ, Hewson SA, Hodnett ED, Saigal S, Willan AR. Planned caesarean section versus planned vaginal birth for breech presentation at term: a randomised multicentre trial. Lancet 2000;356:1375-83.

3. Molkenboer JFM, Bouckaert PXJM, Roumen FJME. Recent trends in breech delivery in the Netherlands. BJOG 2003;110:948-51.

4. Robson S, Ellwood D. Should obstetricians support a "term cephalic trial'? Aust NZ J Obstet Gynaecol 2003;43:341-3.

5. Schutte MF, van Hemel OJ, van de Berg C, van de Pol A. Perinatal mortality in breech presentations as compared to vertex presentations in singleton pregnancies: an analysis based upon 57819 computerregistered pregnancies in The Netherlands. Eur J Obstet Gynecol Reprod Biol 1985:391-400.

6. Jones O, Roder D. Breech presentation in South Australia, 1987-1989. Aust NZ J Obstet Gynaecol 1993;33:17-22.

7. Sibony O, Luton D, Oury JF, Blot P. Six hundred and ten breech versus 12,405 cephalic deliveries at term: is there any diflerence in neonatal outcome? Eur $J$ Ohstet Gynecol Reprod Biol 2003;107:140-4.

8. Molkenboer JFM, Reijners EPJ, Nijhuis JG, Roumen FJME. Moderate neonatal morbidity after vaginal term breech delivery. J Matern Fetal Neonatal Med 2004;16:357-61.

9. Brenner WE. Breech presentation. Clin Obstet Gynecol 1978;21:511-8.

10. Buitendijk SE, Nijhuis JG. High perinatal mortality in the Netherlands compared to the rest of Europe. Ned Tijdschr Geneesk 2004;148:1855-60.

11. Rietberg CCT, Elferink-Stinkens PM, Visser GHA. The effect of the Term Breech Trial on medical intervention behaviour and neonatal outcome in The Netherlands: an analysis of 35,453 term breech infants. BJOG 2005;112:205-9.

12. Schuitemaker N, van Roosmalen J, Dekker G, van Dongen P, van Geijn H, Bennebroek Gravenhorst J. Maternal mortality after cesarean section in The Netherlands. Acta Obstet Gynecol Scand 1997;76:3324.

13. Lydon-Rochelle M, Holt VL, Easterling TR, Martin DP. Association between method of delivery and maternal rehospitalization. JAMA 2000;283;2411-6.

14. Lydon-Rochelle M, Holt VL, Easterling TR, Martin DP. Risk of uterine rupture during labor among women with a prior caesarean section. NEJM 2001;345:3-8.

15. Gilliam $M$, Rosenberg $D$, Davis $F$. The likelihood of placenta previa with greater number of cesarean deliveries and higher parity, Obstet Gynecol 2002;99:976-80. 
How to counsel a pregnant woman with a near term foetus in breech position?

\author{
Molkenboer JFM \\ Roumen FJME \\ Nijhuis JG
}

Adapted from: Reproductieve geneeskunde, gynaecologie en obstetrie anno 2007. p 500-505 


\section{Introduction}

Counselling patients with a foetus in breech position is difficult, since the physician should try to offer information, derived from evidence based data, regardless of personal views. External cephalic version, elective caesarean section and planned vaginal delivery all have advantages and disadvantages. Therefore it is important that all possibilities and options are discussed after which the patient can make an informed decision. Another matter which makes the counselling more difficult is the fact that women are not a homogeneous group in terms of their requirements for information, nor on their desire to be involved in the decision on mode of delivery. ${ }^{1}$ Using a clinical case as example, we discuss the current literature and the process of counselling a patient with a near term foetus in breech position.

A 27-year old pregnant woman is seen at 34 weeks of gestation after referral by her midwife. She is in her first pregnancy, and the baby lies in frank breech position. Her medical history and her pregnancy have been uneventfiul. A structured ultrasonographic investigation at twenty weeks of gestation revealed no abnormalities. She and her partner wish to have two more children in the future. Now they want to know our opinion on the best policy regarding pregnancy and delivery of this child.

Breech presentation at term occurs in $3-4 \%$ of pregnancies. ${ }^{2}$ The number of breech presentations is higher at low gestational age compared to term pregnancy. The incidence of breech presentation is about 30\% at a gestational age of 24-26 weeks. There is a continuous decline towards term to approximately $20 \%$ at 30 weeks, $10 \%$ at 35 weeks and $2 \%$ at 40 weeks. Spontaneous version is less likely in pregnancies with extended foetal legs, low birth weight, short umbilical cord and primiparity. ${ }^{3}$ The frank or extended breech is the most common type of breech presentation at term and occurs in about $75 \%{ }^{4}$

Recent research has confirmed that a breech position is associated with a significantly higher prevalence of foetal congenital malformations. ${ }^{5}$ Therefore, an extensive ultrasound investigation to exclude major congenital abnormalities, should be performed. Other important factors for breech position are a uterine malformation, placenta praevia, the length of the umbilical cord, birth weight, birth order, maternal age and maternal health. All these have been found, to a certain extent, to be associated with breech presentation. ${ }^{6}$

\section{External cephalic version (ECV)}

The pregnant woman wants to know the chance that the baby will turn spontaneously, and if not, what the success rate and the risks of an external version are.

Since the baby is in frank breech position and this is the patients' first pregnancy, the chance on a spontaneous version to a cephalic lie is less than $20 \% .^{3}$ Compared with no ECV attempt, ECV before term reduces non-cephalic births. ${ }^{7}$ Compared with ECV at 
term, ECV between 34 to 35 weeks may have some benefit in terms of decreasing the rate of non-cephalic presentation, and caesarean section. Further trials are needed to confirm this finding and to rule out increased rates of preterm birth, or other adverse perinatal outcomes. A large randomised trial addressing this question is ongoing (see: www.utoronto.ca/miru/eecv2). A Cochrane review of ECV at term (from $37+0$ weeks) reported an increased likelihood that the foetus will be cephalic at delivery, and a reduced caesarean section rate. ${ }^{8}$ Therefore, ECV should be recommended to all women with a breech foetus at term, where there is no contraindication. Absolute contraindications are placenta praevia, multiple pregnancy, ruptured membranes, hyperextension of the foetal head, and an umbilical cord around the foetal neck. ${ }^{9,10}$ Relative contraindications are a previous caesarean section, intrauterine growth retardation or oligohydramnios. ${ }^{9,10}$ The success rate of ECV after 37 weeks gestation has been shown to vary between $35 \%$ and $86 \% .^{11}$ Tocolysis seems to improve the success rates. ${ }^{12}$ A systematic review of version related risks concluded that emergency caesarean sections were performed in $0.43 \%$ of all versions and that perinatal mortality was $0.16 \%{ }^{13}$

\section{Vaginal delivery or caesarean section?}

After informed consent, an ECV attempt was performed which was not successful. Now the pregnant woman wants to be informed about the advantages or the risks of a vaginal delivery versus a caesarean section for her baby.

Management of breech presentation is one of the most debated clinical subjects in obstetrics and has always been a dilemma for the obstetrician. ${ }^{14-16}$ The neonatal mortality and morbidity are estimated to be three to five times that of comparable infants with cephalic presentation, even after excluding prematurity and congenital anomalies. ${ }^{17.18}$ Vaginal delivery has always been regarded upon as an obstetric 'art', and the preferred way of delivery until the late 1950 's. ${ }^{19,20}$ In 1959 , Wright advocated a planned caesarean section in breech presentation at more than 35 weeks of gestation, to reduce perinatal mortality and morbidity. ${ }^{21}$

Before the Term Breech Trial (TBT), cohort studies showed that planned caesarean section is better than planned vaginal birth for the term breech foetus. ${ }^{22,23}$ Two randomised controlled trials and a Cochrane meta-analysis of these trials did not find planned caesarean section to be associated with better results for the foetus, but both trials had very small sample sizes and continuation of research to determine whether a caesarean section for the term breech reduces adverse perinatal outcome was regarded as of great importance. ${ }^{4,24,25}$ In October 2000 , the results of the Term Breech Trial (TBT) were published. ${ }^{26}$ The TBT was a randomised controlled multicentre study, conducted to determine whether a planned caesarean section or a planned vaginal birth is the best mode of delivery for selected foetuses in breech presentation at term. At 121 centres in 26 countries, of which the Atrium Medical Centre Parkstad was the only Dutch participating hospital, 2088 women with a singleton foetus in frank or complete breech presentation were randomly assigned to either a planned caesarean section (CS) or a planned vaginal delivery (VD). The analysis was based on intention to treat. 
The conclusion was that planned caesarean section is better than planned vaginal birth for the term foetus in breech presentation. The risk of perinatal or neonatal mortality or serious neonatal morbidity was three times lower in the planned CS group compared to the planned VD group (1.6\% vs. 5.0\%, 95\% CI 0.33 [0.19-0.56]). A Lancet commentary concluded that there was no more room for disagreement on breech delivery. ${ }^{27} \mathrm{Al}-$ though in terms of evidence based medicine the randomised controlled trial is considered to be the gold standard, the Term Breech Trial received lots of scepticism. Kotaska criticised the results because of bias of license, homogenisation of the study population and clinical intervention by large scale randomisation, resulting in an average level of care in an average population. ${ }^{28}$ Glezerman even advocated that the investigators of the TBT should withdraw their conclusions. ${ }^{29}$

\section{Situation in the Netherlands}

In the Netherlands, the total caesarean section rate for term breech position rose from $50 \%$ in 2000 to $80 \%$ in 2001 and remained stable afterwards. ${ }^{30}$ This resulted in a $50 \%$ reduction in perinatal mortality. ${ }^{31}$ In the period from 2001 to 2003 neonatal mortality after a vaginal trial of labour was $0.38 \%$ versus $0 \%$ after a planned caesarean section. Serious neonatal morbidity occurred in $0.92 \%$ after a vaginal trial of labour against $0.16 \%$ after a planned caesarean section. Combined mortality / severe morbidity occurred in $1.29 \%$ after a vaginal trial of labour and in $0.16 \%$ after elective caesarean section, a difference of more than $1 \% .{ }^{31}$ A recent retrospective population-based study from Canada showed an even lower neonatal mortality. The overall caesarean section rate in that study was $95 \% .^{32}$

\section{Neurodevelopmental outcome of children at two years of age}

Some large retrospective studies reported increased late infant morbidity following breech delivery after planned vaginal mode of delivery. ${ }^{33,34}$ In the TBT, no differences in neurodevelopmental delay in children at two years of age could be demonstrated according to the planned mode of delivery. ${ }^{35}$ These comforting results also received criticism, since this study enclosed only a selected subgroup (44\%). Moreover, in another prospective study it was found that planned vaginal delivery is associated with an increased risk of neurodevelopmental delay at two years in term breech children with a birth weight greater than $3500 \mathrm{~g} .{ }^{36}$ Most retrospective studies found no differences. ${ }^{37-40}$

\section{Maternal mortality and morbidity}

The patient and her partner are also interested in the risks of maternal mortality and morbidity after a caesarean section. 
Having a caesarean section increases the risk of maternal death during delivery. In the Netherlands immediate maternal mortality after caesarean section is estimated to be three times higher than after vaginal birth (1 per 8000). ${ }^{41}$ Data from 2000 to 2002 in the Netherlands show a case fatality rate for elective caesarean section for breech presentation of $0.47 / 1.000$ operations and no death after emergency caesarean section for breech presentation. ${ }^{42}$ This in contrast with foreign research which reported maternal death after an emergency caesarean section to occur four times as frequent compared to an elective caesarean section. ${ }^{43}$ Since half of the planned vaginal deliveries result in an emergency caesarean section one can calculate, based on recent British figures, that the chance for a mother to die after an elective caesarean section is almost equal to that after a planned vaginal delivery. ${ }^{44}$ Based on the data available in the Netherlands the risk for the expectant mother with a term foetus in breech position to die after planned vaginal delivery is 1:12000 (Figure 1). Other studies even demonstrate lower mortality in elective caesarean delivery than in vaginal delivery. ${ }^{45,46}$

\section{Consequences for the next pregnancy and birth}

Now the pregnant woman and her partner wonder whether the information given is complete.

Most reports on maternal mortality discount the risk of death in the subsequent pregnancies, due to increased risks of uterine rupture, placenta praevia, placenta accreta and ectopic pregnancy. ${ }^{47-49}$ It is not certain whether a prior caesarean section accounts for a higher risk in stillbirth in the next pregnancy. ${ }^{50-53}$

In the Netherlands $71,7 \%$ of the women starts with a trial of labour after a previous caesarean section and $76 \%$ succeeds, which results in $54,4 \%$ vaginal deliveries after a previous caesarean section. ${ }^{54}$ The price to be paid is a higher risk of uterine ruptures. In the Netherlands the chance of having a uterine rupture after a previous caesarean section is $1.1 \%$. Almost all occurred after a trial of labour $(98 \%)$. The uterine ruptures resulted in a perinatal mortality of $0.12 \%$. The chance for a expectant mother to die after a previous caesarean section is calculated to be $0.0036 \%$, or 1 in 28.000 women. It's not clear if this chance is influenced by the planned route of delivery. ${ }^{55,56}$

The chance on an emergency caesarean section after planned vaginal term breech delivery in the Netherlands is approximately $50 \%(49.4 \%){ }^{5}$ This means that for the next child in the subsequent pregnancy the extra risk on neonatal mortality is 1 in $1666(0.5 \mathrm{x}$ $0.12 \%$ ), due to the risk of a uterine rupture (Figure 1). The absolute risk on neonatal mortality for the first and second child together is therefore one in 833 in the planned caesarean section group and one in $227(1: 263$ plus 1:1666) in the planned vaginal birth group. 


\section{Induction of labour, pain relieve and attendance of the delivery}

The pregnant woman prefers a trial of vaginal labour. She wants some add: information on procedures like induction of labour, pain relieve and attendan.

The purpose of an induction is to deliver the foetus vaginally. Patients with a $\mathbf{s}$ uterus, premature rupture of membranes, or prolonged pregnancy are not conside be appropriate candidates for trial of labour. So the use of oxytocin for induct augmentation (because of the risk of undiagnosed foetopelvic disproportion) is 1 able avoided. ${ }^{57}$ In a secondary analysis of the TBT the risk of adverse perinatal ou was increased by augmentation of labour but not for induction of labour. ${ }^{58}$ So thi for augmentation of labour with oxytocin could be a marker for inadequate labo sulting in adverse perinatal outcome.

Pain relief with epidurals is in the Netherlands scarcely offered to women with $\mathbf{v}$ breech deliveries because of fear that the parturient will not be able to push effec during the second stage of labour.

In $71 \%$ of all obstetrical departments in the Netherlands, there is unanimous poli term breech vaginal delivery. ${ }^{5}$ This means that the individual obstetrician on $\mathrm{c}$ : cides during labour whether there is sufficient progress and whether continuation planned vaginal breech delivery is acceptable. Conditions for accepting a vaginal ery are normal progression of first and second stage of labour without signs of in1 tum asphyxia.

\section{Conclusion}

Thorough counselling on the mode of delivery of a term breech baby is difficu time consuming. It should be objective and unprejudiced. Using a chart may be 1 to explain the neonatal and matemal risks to the expectant patient (Figure 1: woman is certain that she only wants one child, an elective caesarean section app be the better option. For a planned vaginal delivery both a motivated expectant $\mathbf{r}$ as well as a motivated doctor are important conditions. Still, it should be made cle the chance of getting an emergency caesarean section when choosing for a $\mathbf{p}$ ] vaginal delivery is approximately $50 \%$. 


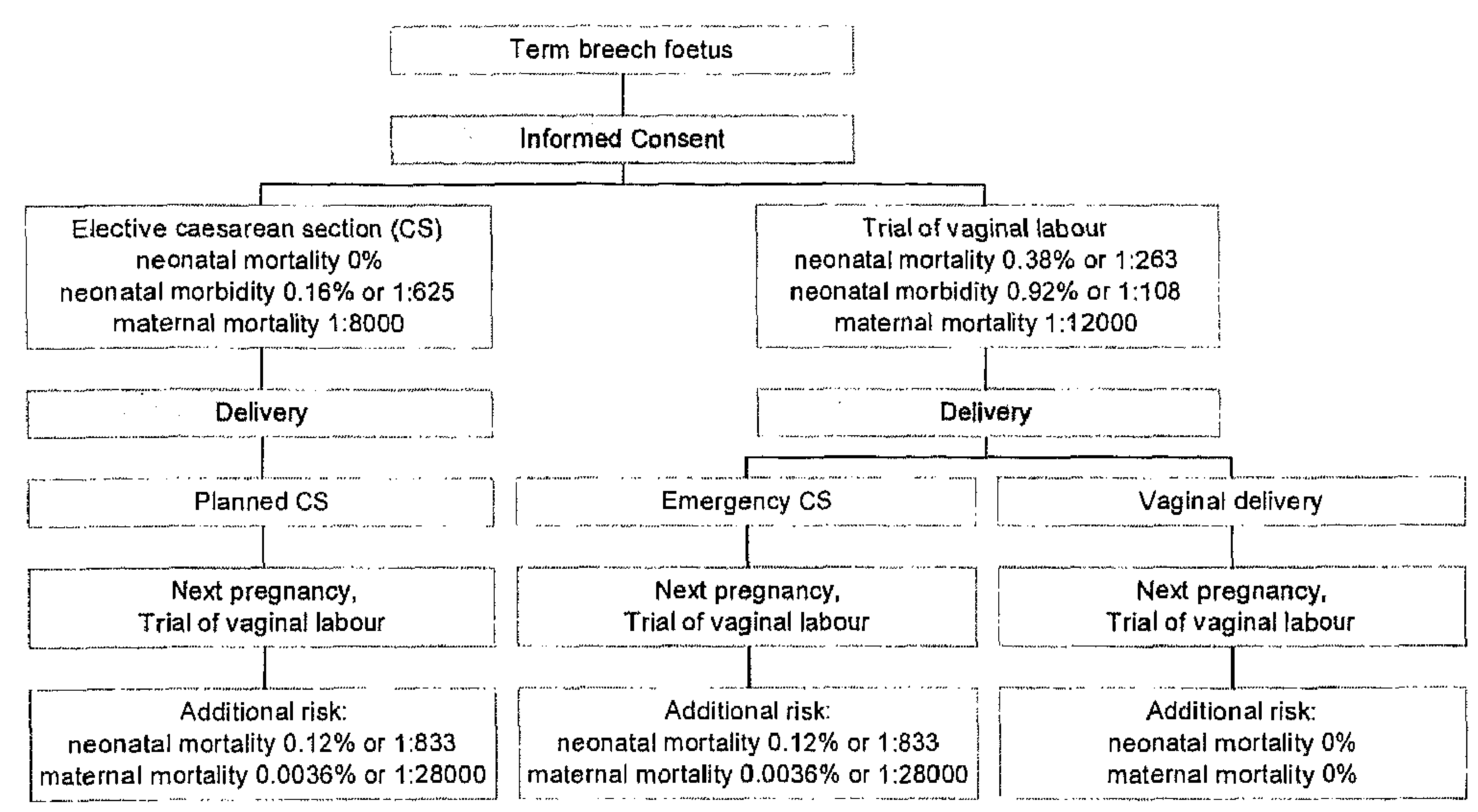

Figure 1. Neonatal mortality and morbidity risks, and maternal morlality risks in the Netherlands according to the planned mode of delivery of a term breech foetus in the first pregnancy, and the additional neonatal and maternal mortality risks followed by a trial of vaginal labour in the next pregnancy. 


\section{References}

1. Graham WJ, Hundley V. McCheyne AL, Hall MH, Gurney E, Milne J. An investigation of women's involvement in the decision to deliver by caesarean section. Br J Obstet Gynaecol 1999;106:213-20.

2. Ilickok DE, Gordon DC, Milberg JA, Williams MA, Daling JR. The frequency of breech presentation by gestational age at birth: a large population-based study. Am J Obstet Gynecol 1992;166:851-2.

3. Westgren M, Edvall H, Nordström L, Svalenius E. Spontancous cephalic version of breech presentation in the last trimester. BJOG 1985;92:19-22.

4. Collea JV, Chein C, Quilligan EJ. The randomized management of term frank breech presentation: a study of 208 cases. Am J Obstet Gynecol 1990;137:235-44.

5. Rietberg CCT. Term breech delivery in The Netherlands. Thesis 2006, Utrecht.

6. Albrechtsen A, Irgens LM. Epidemiology and aetiology of breech presentation. In Künzel W, volume editor. Breech delivery. 1 st ed. European practice in gynaecology and obstetrics; 2002. p 17-25.

7. Hutton E, Hofmeyr G. External cephalic version before term. Cochrane Database Syst Rev 2006;(1):CD000084.

8. Hofmeyr GJ, Kulier R. External version for breech presentation at term. Cochrane Database Syst Rev 2000;(2):CD000083.

9. Myerscough P. The practice of external cephalic version. Br J Obstet Gynaecol 1998;105:1043-5.

10. Norchi S, Tenore AC, Lovotti M, Merati R, Teatini A, Belloni C. Efficacy of external cephalic version performed at term. Eur J Obstet Gynecol Reprod Biol 1998;76:161-3.

11. ACOG practice bulletin. External cephalic version. Int J Gynaecol Obstet 2001;72:198-204.

12. Hofimcyr GJ. Interventions to help external cephalic version for breech presentation at term. Cochrane Database Syst Rev 2004;(1):CD000184.

13. Collaris RJ, Oei SG. External cephalic version: a safe procedure? A systematic review of version-related risks. Acta Obstet Gynecol Scand 2004;83:511-8.

14. Ghosh MK. Breech presentation, evolution of management. J Reprod Med 2005;50:108-16.

15. Confino E, Gleicher N, Elrad H et al. The breech dilemma. Obstet Gynecol Surv 1985;40:330-7.

16. Myers SA, Gleicher N. Breech delivery: why the dilemma? Am J Obstet Gynecol 1987;156:6-10.

17. Fischer-Rasmussen $W$, Trolle $D$. Abdominal versus vaginal delivery in breech presentation. Acta Obstet Gynecol Scand 1967;46:69-76.

18. Rovinsky JJ, Miller JA, Kaplan S. Management of breech presentation at term. Am J Obstet Gynecol 1973;115:497-513.

19. Bowes WA, Taylor ES, O'Brien M, Bowes C. Breech delivery: evaluation of the method of delivery on perinatal results and maternal morbidity. Am J Obstet Gynecol 1979;135:965-73.

20. Greenhill JP (editor). The Year Book of Obstetrics and Gynecology. Chicago, Year Book Medical Publishers;1975. p 160-1.

21. Wright RC. Reduction of perinatal mortality and morbidity in breech delivery through routine use of cesarean section. Obstet Gynecol 1959;14:758-63.

22. Cheng $M$, Hannah ME. Breech delivery at term: a critical review of the literature. Obstet Gynecol 1993;82:605-18.

23. Gifford DS, Morton SC, Fiske M, Kahn K. A meta-analysis of infant outcomes after breech delivery. Obstet Gynecol 1995;85:1047-54.

24. Gimovsky MI, Wallace RL, Schifrin BS, Paul RH. Randomized management of the nonfrank breech presentation at term: a preliminary report. Am J Obstet Gynecol 1983;146:34-40.

25. Hofmeyr GJ, Hannah ME. Planned caesarean section for term breech delivery. Cochrane Database Syst Rev 2000;(2):CD000166.

26. Hannah ME, Hannah WJ, Hewson SA, Hodnett ED, Saigal S, Willan A et al. Planned caesarean section versus planned vaginal birth for breech presentation at term: a randomised multicentre trial. Lancet 2000;356:1375-83.

27. Lumley J. Any room left for disagreement about assisting breech births at term? Lancet 2000;356:136970.

28. Kotaska A. Inappropriate use of randomised trials to evaluate complex phenomena: a case study of vaginal breech delivery. BMJ 2004;329:1039-42. 
29. Glezerman M. Five years to the term breech trial: The rise and fall of a randomized controlled trial. Am J Obstet Gynecol 2006;194:20-5.

30. Molkenboer JFM, Bouckaert PXJM, Roumen FJME. Recent trends in breech delivery in the Netherlands. BJOG 2003;110:948-51.

31. Rietberg CCT, Elferink-Stinkens PM, Visser GHA. The effect of the Term Breech Trial on medical intervention behaviour and neonatal outcome in The Netherlands: an analysis of 35,453 term breech children. BJOG 2005;112:205-9.

32. Gilbert W, Hicks SM, Boe NM, Danielsen B. Vaginal versus cesarean delivery for breech presentation in California: a population-based study. Obstet Gynecol 2003;102:911-7.

33. Bistoletti P, Nisell H, Palme C, Lagercrantz H. Term breech delivery: early and late complications. Acta Obstet Gynecol Scand 1981;60:165-71.

34. Svenningsen NW, Westgren M, Ingemarsson I. Modern strategy for the term breech delivery- a study with 4-year follow-up of the infants. J Perinat Med 1985;13:117-26.

35. Whyte $H$, Hannah ME, Saigal S, Hannah WJ, Hewson S, Amankwah $K$ et al. Outcomes of children at 2 years after planned cesarean versus planned vaginal delivery for breech presentation at term: the international randomized Term Breech Trial. Am J Obstet Gynecol 2004;191:864-71.

36. Molkenboer JFM, Roumen FJME, Smits LJM, Nijhuis JG. Birth weight and neurodevelopmental outcome of children at 2 years of age after planned vaginal delivery for breech presentation at term. Am J Obstet Gynecol 2006; 194:624-9.

37. Rosen MG, Debanne S, Thompson K, Bilenker RM. Long-term neurological morbidity in breech and vertex births. Am J Obstet Gynecol 1985;151:718-20.

38. Danielian PJ, Wang J, Hall MH. Long term outcome by method of delivery of fetuses in breech presentation at term: population based follow up. BMJ 1996;312:1451-3.

39. Münstedt K, Georgi von R, Reucher S, Zygmunt M, Lang U. Term breech and long-term morbiditycesarean section versus vaginal breech delivery. Eur J Obstet Gynecol Reprod Biol 2001 ;96:163-7.

40. Krebs L, Langhoff-Roos J. The relation of breech presentation at term to epilepsy in childhood. Eur J Obstet Gynecol Reprod Biol 2006;127:26-8.

41. Schuitemaker N, van Roosmalen J, Dekker G, van Dongen P, van Geijn H, Bennebroek Gravenhorst J. Maternal mortality after cesarean section in The Netherlands. Acta Obstet Gynecol Scand 1997;75:3324.

42. Schutte JM, Stccgers EA, Santema JG, Schuitemaker NW, van Roosmalen J. Maternal death after elective cesarean section for breech presentation in the Netherlands. Acta Obstet Gynecol Scand 2007;86:240-3.

43. Bingham P, Lilford RJ. Management of the selected term breech presentation: assessment of the risks of selected vaginal delivery versus cesarean section for all cases. Obstet Gynecol 1987;69:965-78.

44. Visser GHA, Rietberg CCT, Oepkes D, Vandenbussche FPHA. Stuitligging: kind versus moeder. Ned Tijdschr Geneeskd 2005;149:2211-4.

45. Lucas DN, Yentis SM, Kinsella SM Holdcrof A, May AE, Wee M et al. Urgency for cesarean section: a new classification. J R Soc Med 2000;93:346-50.

46. Yoles I, Maschiach S. Increased maternal mortality in cesarean section as compared to vaginal delivery? Time for re-evaluation. Am J Obstet Gynccol 1988;178:Suppl:S78. abstract.

47. Hemminki E, Meriläinen J. Long-term effects of cesarean sections: ectopic pregnancies and placental problems. Am J Obstet Gynecol 1996;174:1569-74.

48. Lydon-Rochelle M, Holt VL, Easterling TR, Martin DP. Risk of uterine rupture during labor among women with a prior cesarean section. NEJM 2001;345:3-8.

49. Gilliam M, Rosenberg D, Davis F. The likelihood of placenta previa with greater number of cesarean deliveries and higher parity. Obstet Gynecol 2002;99:976-80.

50. Smith GC, Pell JP, Dobbie R. Caesarean section and risk of unexplained stillbirth in subsequent pregnancy. Lancet 2003;362:1779-84.

51. Bahtiyar MO, Julien S, Robinson JN, Lumey L, Zybert P, Copel JA et al. Prior cesarean delivery is not associated with an increased risk of stillbirth in a subsequent pregnancy: analysis of U.S. pcrinatal mortality data, 1995-1997. Am J Obstet Gynecol 2006;195:1373-8.

52. Gray R, Quigley MA, Hockley C, Kurinczuk JJ, Goldacre M, Brocklehurst P. Caesarean delivery and risk of stillbirth in subsequent pregnancy: a retrospective cohort study in an English population. BJOG $2007 ; 114: 264-70$ 
53. Kennare R., Tucker G, Heard A, Chan A. Risks of adverse outcomes in the next birth after a first caesarean delivery. Obstet Gynecol 2007;109:270-6.

54. Kwee A. Caesarean section in the Netherlands. Policy, prevention and long-term consequences. Thesis 2005, Utrecht.

55. Wen SW, Rusen ID, Walker M, Liston R, Kramer MS, Baskett T et al. Comparison of maternal mortality and morbidity between trial of labor and elective cesarean section among women with previous cesarean delivery. An J Obstet Gynecol 2004;191:1263-9.

56. Landon MB, Hauth JC. Leveno KJ, Spong CY, Leindecker S, Varner MW et al. Maternal and perinatal outcomes associated with a trial of labor after prior cesarean delivery. N Engl J Med 2004;351:2581-9.

57. Vidaeff AC. Breech delivery before and after the Term Breech Trial. Clin Obstet Gynecol 2006;49:198210.

58. Su M, McLeod L, Ross S, Willan A, Hannah WJ, Hutton EK et al. Factors associated with adverse perinatal outcome in the Term Breech Trial. Am J Obstet Gynecol 2003;189:740-5. 
Epilogue 
In the Netherlands, as in many other countries around the world, the publication of the Term Breech Trial led to a huge debate among obstetricians ${ }^{1-5}$ Following the publication the total caesarean section percentage for term singleton breeches increased from $50 \%$ to $80 \%{ }^{6}$ This new policy led in the Netherlands to a significant reduction in neonatal mortality and short term neonatal morbidity. ${ }^{7}$ Long term neonatal morbidity results were not conclusive. ${ }^{8-14}$ In our prospective study we found that planned vaginal delivery is associated with an increased risk of neurodevelopmental delay at two years in term breech children with a birth weight greater than $3500 \mathrm{~g} .{ }^{15}$

The results of the Term Breech Trial showed no differences in short and long term maternal mortality or morbidity. ${ }^{16.17}$ Also, in our studies no differences were found in short or long term follow-up. ${ }^{18,19}$ We did find that more women with a planned vaginal delivery were worried about the health of their baby at the time of delivery, experienced more pain than expected, and reported less involvement in decision-making. ${ }^{20}$

One of the arguments against the conclusions of the Term Breech Trial are the possible increased maternal mortality and morbidity in the subsequent pregnancy, described in various studies, due to uterine rupture, placenta accrete, placenta increta and ectopic pregnancies. ${ }^{21-26}$

In the Netherlands, the maternal mortality after a caesarean section seems to be three times as high as after a vaginal delivery. ${ }^{27}$ Other studies have reported maternal mortality after an emergency caesarean section to occur twice as frequent compared to an elective caesarean section. ${ }^{28-30}$ In the Netherlands approximately $50 \%$ of the started vaginal deliveries for term breech presentation end in an emergency caesarean section. ${ }^{31}$ Given this information the chance on maternal mortality seems about equal after an elective caesarean section or planned vaginal delivery for a term foetus in breech presentation. The most important goal is to prevent the emergency caesarean section in term breech delivery.

Still, too little research has been performed on the possible differences between the long term maternal mortality and morbidity, when comparing the elective caesarean section with the emergency caesarean section, as well as the possible factors attributable for a greater risk on uterine ruptures. Imaging techniques may improve the early detection of uterine dehiscence but in the acute setting abnomal foetal heart rate patterns provide early diagnostic information. ${ }^{32}$ If a woman is certain that she only wants one child, an elective caesarean section appears to be the better option.

\section{Preterm breech trial}

A randomised controlled trial to address the same clinical dilemma for the preterm breech foetus has never been performed. There have been studies that both support and refute caesarean section in preterm foetuses in breech position. ${ }^{33}$ Also long term followup is not conclusive. Two Dutch follow-up studies gave opposite results, one suggested a reduced neonatal mortality rate in preterm breech foetuses born by caesarean section, whereas the other found no increased survival after a policy of caesarean section. ${ }^{34,35}$

A randomised controlled trial seems to be the most proper way to address this question, but this would have to be a multicentre trial because of the numbers needed, and Ko- 
taska's arguments against the term breech trial would also account for this study. ${ }^{36}$ It is therefore unlikely that such a study will be realized in the forthcoming years.

\section{External cephalic version}

External cephalic version is proven to be a valuable tool to diminish the percentage of caesarean sections ${ }^{37}$ Therefore, external cephalic version should be recommended to all women with a breech foetus at term, after excluding possible contraindications. A systematic review of version related risks concluded the risk on an emergency caesarean section to be $0.43 \%$ and $0.16 \%$ perinatal mortality. ${ }^{38}$ Considering these risks an external cephalic version should be performed in an environment where acute obstetrical interference, e.g. a caesarean section, is possible.

\section{Long term follow-up}

More research is needed on long term follow-up of selected groups in prospective studies. Currently, from the same cohort studied in this thesis, the children are prospectively followed up to eight years of age.

Also, the long term maternal consequences are very important to study. We have a reasonable accurate system to collect data on all breech deliveries (LVR-2, see Chapter 2) in the Netherlands. However, because of privacy reasons one cannot connect consecutive deliveries of a woman. Therefore, it is advised to introduce a unique labour number for every pregnant woman, which makes long term follow-up of consecutive pregnancies possible, while preserving the privacy of the patient. This will give investigators the opportunity to detect epidemiological trends occurring due to changed obstetrical care. With thorough and continuous long term research, we may learn whether the chosen and seemingly irreversible trend of performing more and more caesarean sections on term breech babies has been the right choice for both mother and child. 


\section{References}

1. Verhoeven ATM. Keizersnede bij stuitligging? Medisch Contact 2000;48:1703.

2. van Roosmalen $\mathrm{J}$, Rosendaal $\mathrm{F}$. There is still room for disagreement about vaginal delivery of breech intants at term. BJOG 2002;109:967-9.

3. de Leerw JP, ATM Verhoeven. De 'Term Breech Trial' (TBT), 5 maanden verder. NTOG 2001;1 14:148-9.

4. Roumen FJME, Nijhuis JG. De aterme stuitligging: keuze voor keizersnede. NTVG 2001;145:1533-6.

5. Buitendijk SE. Problemen met de stuit. NTOG 2001;114:230-5.

6. Molkenboer JFM, Bouckaet PXJM, Roumen FJME. Recent trends in breech delivery in the Netherlands. BJOG 2003;110:948-51

7. Bistoletti P, Nisell II, Palme C, Lagercrantz H. Term breech delivery: early and late complications. Acta Obstet Gynecol Scand 1981;60:165-71.

8. Svenningsen NW, Westgren M. Ingemarsson I. Modern strategy for the term breech delivery- a study with 4-year follow-up of the infants. J Perinat Med 1985;13:1 17-26.

9. Rosen MG, Debanne S. Thompson K, Bilenker RM. Long-term neurological morbidity in breech and vertex births. Am J Obstet Gynecol 1985;151:718-20.

10. Danielian PJ. Wang J, Hall MII. Long term outcome by method of delivery of fetuses in breech presentation at term: population based follow up. BMJ 1996;312:145!-3.

11. Minstedt K, Georgi von R, Reucher S, Zygmunt M, Lang U. Term breech and long-term morbiditycesarean section versus vaginal breech delivery. Eur J Obstet Gynecol Reprod Biol 2001;96:163-7.

12. Whyte H, Hannah ME, Saigal S, Hannah WJ, Hewson S, Amankwah K et al. Outcomes of children at 2 years after planned cesarean versus planned vaginal delivery for breech presentation at term: the international randomized Term Breech Trial. Am J Obstet Gynecol 2004;191:864-71.

13. Rietberg CCT, Elferink-Stinkens PM, Visser GHA. The effect of the Term Breech Trial on medical intervention behaviour and neonatal outcome in The Netherlands: an analysis of 35,453 term breech infants. BJOG 2005;1 12:205-9.

14. Krebs L, Langhoff-Rous J. The relation of breech presentation at term to epilepsy in childhood. Eur J Obstet Gynecol Reprod Biol 2006;127:26-8.

15. Molkenboer JFM, Roumen FJME, Smits LJM, Nijhuis JG. Birth weight and neurodevelopmental outcome of children at 2 years of age after planned vaginal delivery for breech presentation at term. Am J Obstet Gynecol 2006;194:624-9.

16. Hannah ME, Hannah WJ, Hodnett E, Chalmers B, Kung R, Willan A et al. Outcomes at 3 months after planned caesarean versus planned vaginal delivery for breech presentation at term: the international Term Breech Trial. JAMA 2002;287;1 822-31.

17. Hannah ME, Whyte I, Walter J, Hewson S, Amankwah K, Cheng M et al. Maternal outcomes at 2 years after planned cesarean section versus planned vaginal birth for breech presentation at term: the international Term Breech Trial. Am J Obstet Gynecol 2004;191:917-27.

18. Molkenboer JFM, Reijners EPJ, Nijhuis JG, Roumen FJME. Moderate neonatal morbidity after vaginal lerm breech delivery. J Matern Fetal Neonatal Med 2004:16:357-61.

19. Molkenboer JFM, Debie S, Roumen FJME, Smits LJM, Nijhuis JG. Maternal health outcomes two years after term breech delivery. J Matern Fetal Neonatal Med 2007;20:599-603.

20. Molkenboer JFM, Debie S, Roumen FJME, Smits LJM, Nijhuis JG. Mothers' views two years after term breech delivery. J Psychosom Obstet Gynaecol 2007; Jul 19:1-6 [Epub ahead of print].

21. Ananth CV, Smulian JC, Vintzileos AM. The association of placenta previa with history of caesarean delivery and abortion: a metaanalysis. Am J Obstet Gynecol 1997;177:1071-8.

22. van Ham MA, van Dongen PW, Mulder J. Maternal consequences of caesarean section. A retrospective study of intra-operative and post-operative maternal complications of caesarean section during a 10 -year period. Eur J Obstet Gynecol Reprod Biol 1997;74:1-6.

23. Irion $O$. Hirsbrunner Almagbaly $P$, Morabia A. Planned vaginal delivery versus elective caesarean section: a study of 705 singleton term breech presentations. Br J Obstet Gynaecol 1998;105:710-7.

24. Lydon-Rochelle M, Holt VL, Martin DP, Easterling TR. Association between method of delivery and naternal rehospitalization. JAMA 2000;283:2411-6. 
25. Lydon-Rochelle M, Holt VL, Easterling TR, Martin DP. Risk of uterine rupture during labor among women with a prior cesarean delivery. NEJM 2001;345:3 8.

26. Hemminki E, Meriläinen J. Long-term effects of cesarean sections: ectopic prcgnancies and placental problems. Am J Obstet Gynecol 1996;174:1569-74.

27. Schuitemaker N, van Roosmalen J, Dekker G, van Dongen P, van Geijn H, Bennebroek Gravenhorst J. Maternal mortality after cesarean section in The Netherlands. Acta Obstet Gynecol Scand 1997;76:3324.

28. Bingham P, Lilford RJ. Management of the selected term breech presentation: assessment of the risks of selected vaginal delivery versus cesarean section for all cases. Obstet Gynecol 1987;69:965-78.

29. Hall MM. Caesarean section. In Lewis G, editor. Why mothers die 1997-1999. The confidential enquiries into maternal deaths in the United Kingdom. Ch 22. London: RCOG press; 2001.

30. Lewis $G$. Introduction and key findings 2000-2002. In Lewis $G$, editor. Why mothers die 2000-2002. The confidential enquiries into maternal deaths in the United Kingdom. Ch 1. London: RCOG press; 2004.

31. Rietberg CC.T. Term breech delivery in The Netherlands. Thesis 2006 , Utrecht.

32. Murphy DJ. Uterine rupture. Curr Opin Obstet Gynecol 2006;18:135-40.

33. Yamamura Y, Ramin KD, Ramin SM. Trial of vaginal breech delivery: current role. Clin Obstet Gynecol 2007;50:526-36.

34. Gravenhorst JB, Schreuder AM, Veen S, Brand R, Verloove-Vanhorick SP, Verweij RA et al. Breech delivery in very preterm and very low birthweight infants in The Netherlands. Br J Obstet Gynaecol 1993:100:411-5

35. Wolf H, Schaap AH, Bruinse HW, Solders-de Haas H, van Erthruggen I, Treffers PE. Vaginal delivery compared with caesarean section in early preterm breech delivery: a comparison of long term outcome. Br J Obstet Gynaecol 1999;106:486-91.

36. Kotaska A. Inappropriate use of randomised trials to evaluate complex phenomena: a case study of vaginal breech delivery. BMJ 2004;329:1039-42.

37. Hofmeyr GJ, Kulier R. External cephalic version for breech presentation at term. Cochrane Database Syst Rev 2000;(2):CD000083. Review.

38. Collaris RJ, Oei SG. External cephalic version: a safe procedure? A systematic review of version-related risks. Acta Obstet Gynecol Scand 2004;83:51 1-8. 
Summary 
$311+11 ! 11$

Breech presentation at term occurs in $3-4 \%$ of pregnancies. Due to its frequent occurrence all obstetricians will have to deal with this type of presentation and the possible obstetrical problems during breech delivery.

In chapter 1 a brief review of the history of management of breech delivery is given and an introduction and description of the aim of the thesis is described.

The change in obstetric practice in the Netherlands after the publication of the results of the Term Breech Trial is described in chapter 2. The effect of this randomised controlled trial, published in the Lancet in October 2000, on the mode of delivery of babies in breech presentation in the Netherlands was subject of this study. An immediate amplifying impact on top of the already existing trend of rising caesarean section rates for term singleton breech presentations was observed after this publication. The overall caesarean section percentage of term breeches rose from $50 \%$ in 2000 to $80 \%$ in 2001 . The willingness of obstetricians in the Netherlands to adopt the conclusions of the Term Breech Trial so quickly originate from scientific, legal, psychological and emotional sources. The same amplifying impact applied for all non-term breeches and breeches from multiple gestations, but not for babies in other than breech presentation.

In chapter 3 the short term neonatal and maternal results of a non-randomised group are compared with those of the Term Breech Trial. During the investigation period prospective data were collected on all deliveries of term babies in breech presentation. Part of the pregnant women were included in the Term Breech Trial and randomised in a planned caesarean section group and a planned vaginal delivery group. The remaining non-randomised women were divided in a primary caesarean section group and a started vaginal delivery group. Neonatal and maternal mortality and morbidity were analysed retrospectively, according to the intended mode of delivery.

In none of the groups neonatal or maternal mortality occurred. Neither in the randomised group nor in the non-randomised group significant differences in serious neonatal and maternal morbidity were observed between the intended caesarean section group and the group that started vaginal delivery. However, in the non-randomised group moderate neonatal morbidity was significantly lower in the primary caesarean section group compared to the started vaginal delivery group.

The differences in moderate neonatal morbidity in our non-randomised study group support the conclusion of the Term Breech Trial, that primary caesarean section may be safer for the term breech baby than a trial of vaginal labour.

In chapter $\mathbf{4}$ is determined whether, in a prospective cohort study, planned vaginal delivery for the term singleton breech baby in breech position increases the risk of abnormal neurodevelopment at two years of age, and assessed whether the effect is modified by birth weight. At two years of age, all non-randomised children born in breech position during participation in the Term Breech Trial, were screened for abnormal neurodevelopment with the Ages and Stages Questionnaire (ASQ). The ASQ is a parent-completed child monitoring system which has been validated against the Bayley Scales of Infant Development as a screening tool for abnormal neurodevelopment. 
An ASQ at two years of age was obtained in 183 of 203 children (90.1\%). Twenty-eight percent of these children showed one or more abnormal ASQ domains. There were no differences in the risk of having abnormal ASQ domains between planned vaginal delivery and planned caesarean section $(\mathrm{p}=0.99)$. There was, however, evidence of interaction between mode of delivery and birth weight, with significantly higher risk in neurodevelopmental delay in children over 3500 grams with planned vaginal birth (adjusted OR for interaction term, 3.37; 95\% CI, 1.14-9.95).

Based on the ASQ results at two years of age it was concluded that, planned vaginal delivery is associated with an increased risk of neurodevelopmental delay at two years of age in term breech children with a birth weight above 3500 grams.

In chapter 5 the results are described of the maternal health outcomes in the same prospective cohort study, two years after term breech delivery. Mothers were asked to fill out questionnaires at two years postpartum to judge their health in the previous three to six months. Outcomes of the planned caesarean section group were compared with outcomes of the planned vaginal delivery group, whether or not a vaginal birth was realized or an emergency caesarean section was performed.

One hundred and eighty-three women completed a follow-up questionnaire at two years postpartum. No differences in maternal experiences concerning breastfeeding, taking care of her child and the relationship with her partner were found between the two groups. Also no differences were found in all investigated maternal health items, nor in sexual activity or fertility.

In conclusion, maternal health outcomes two years after term breech delivery were similar after planned caesarean section and planned vaginal delivery.

In chapter 6 the evaluation is given of mothers' views of their childbirth experience in the same prospective cohort study, two years after term breech delivery. Two years after delivery mothers were asked to fill out a questionnaire concerning their breech birth experience and their view about the care provided to them while giving birth. Outcomes of the planned caesarean section group were compared with outcomes of the planned vaginal delivery group, whether or not a vaginal birth was realized or an emergency caesarean section was performed.

Significantly more women in the planned caesarean section group were reassured about their baby's health at the time of delivery $(67.4 \%$ vs. $37.9 \%, p=0.0006)$, whereas more women in the planned vaginal delivery group were worried about their baby's health at the time of delivery ( $45.0 \%$ vs. $25.6 \%, p=0.02$ ). Also, significantly more women in the planned vaginal delivery group experienced more pain during labour and delivery than expected $(46.9 \%$ vs. $18.5 \%, p=0.008)$. In the planned vaginal delivery group significantly less women indicated they had an active say in decision-making $(59.1 \% \mathrm{vs}$. $85.3 \%, \mathrm{p}=0.001$ ).

Evaluation of the mothers' views of their childbirth experience two years after term breech delivery showed that more women in the planned vaginal delivery group recalled having been worried about their child's health at the time of delivery, experienced more pain than expected, and reported less involvement in decision-making. 
In chapter 7 the neonatal mortality and morbidity between breech and cephalic presentations at term are compared in the period before the publication of the Term Breech Trial. In this period, in the Netherlands, a rather conservative management in breech deliveries was being followed. All breech presentations were matched with two cephalic presentations. Eleven hundred and nineteen deliveries were included. In both groups no perinatal mortality occurred. No differences were observed in percentages of children with serious or moderate neonatal morbidity between the breech and cephalic lies. Although the numbers are small, this study shows that a conservative (vaginal) approach in selected foetuses in breech position can be safely pursued with neonatal results similar to foetuses in cephalic presentation.

In chapter 8, we discuss the process of counselling a patient with a near term foetus in breech position, using a clinical case as example. Thorough counselling on the mode of delivery of a term breech baby is difficult and time consuming. It should be objective and unprejudiced. Using a diagram may be helpful to explain the neonatal and maternal risks to the expectant patient. If a woman is certain that she only wants one child, an elective caesarean section appears to be the better option. An external cephalic version should be recommended to all women with breech foetus at term, when there is no contraindication. For a planned vaginal delivery both a motivated expectant mother as well as a motivated doctor are important conditions. Still, it should be made clear that the chance of getting an emergency caesarean section when choosing a planned vaginal delivery is approximately $50 \%$.

In chapter 9 an epilogue is given as well as recommendations for future research. 
Nederlandstalige samenvatting 
In $3-4 \%$ van alle voldragen zwangerschappen ligt het kind in stuitligging. Vanwege dit frequente voorkomen zullen alle gynaecologen van tijd tot tijd worden geconfronteerd met dit type ligging en de mogelijk daarmee gepaard gaande verloskundige problemen tijdens de bevalling.

In hoofdstuk 1 wordt een kort overzicht gegeven van de geschiedenis van de stuitbevalling en wordt het doel van het proefschrift beschreven. Aanleiding was de Term Breech Trial, een grote gerandomiseerde studie waaraan 121 centra in 26 landen over de hele wereld, waaronder het Atrium Medisch Centrum Parkstad, deelnamen. Deze studie, waarvan de resultaten in oktober 2000 werden gepubliceerd, concludeerde dat voor een voldragen kind in stuitligging een geplande keizersnede veiliger is dan een geplande vaginale baring.

In hoofdstuk 2 wordt het effect van de Term Breech Trial beschreven op de wijze van bevallen van kinderen in stuitligging in Nederland. Na publicatie van deze gerandomiseerde studie in de Lancet in oktober 2000 ontstond een onmiddellijke scherpe stijging van het percentage keizersneden voor voldragen kinderen in stuitligging, boven op een al bestaande stijgende trend. Het totale keizersnede percentage voor voldragen kinderen in stuitligging steeg van $50 \%$ in 2000 naar $80 \%$ in 2001 . De bereidheid van de Nederlandse gynaecologen om de conclusies van de Term Breech Trial zo snel over te nemen komt voort uit wetenschappelijke, juridische, psychologische en emotionele overwegingen. Hetzelfde versterkende effect op het percentage keizersneden gold ook voor alle niet voldragen kinderen in stuitligging en voor stuitliggingen bij meerlingzwangerschappen, maar niet voor kinderen anders dan in stuitligging.

In hoofdstuk 3 worden de neonatale en maternale mortaliteit en morbiditeit zes weken na de bevalling van een niet-gerandomiseerde groep voldragen baringen in stuitligging vergeleken met die van de Term Breech Trial. Tijdens de onderzoeksperiode zijn prospectief data verzameld van alle bevallingen van voldragen kinderen in stuitligging. Een deel van de zwangere vrouwen werd geincludeerd in de Term Breech Trial en gerandomiseerd voor ofwel een geplande keizersnede ofwel een geplande vaginale baring. De resterende niet-gerandomiseerde vrouwen werden ook verdeeld in een geplande keizersnede groep en een groep die startte met een vaginale baring. Retrospectief werden neonatale en matemale mortaliteit en morbiditeit geanalyseerd, overeenkomstig de geplande manier van bevallen.

In geen van de groepen was er sprake van neonatale of maternale mortaliteit. Noch in de gerandomiseerde groep, noch in de niet-gerandomiseerde groep werden significante verschillen gevonden in ernstige neonatale morbiditeit en maternale morbiditeit tussen de geplande keizersnede groep of de geplande vaginale baring groep. Echter, in de nietgerandomiseerde groep was de matige neonatale morbiditeit significant lager in de geplande keizersnede groep dan in de gestarte vaginale baring groep.

De verschillen in matige neonatale morbiditeit ondersteunen de conclusie van de Term Breech Trial dat een geplande keizersnede voor een voldragen kind in stuitligging veiliger is dan een poging tot vaginale baring. 
In hoofdstuk 4 is in een prospectieve studie onderzocht of voor een voldragen eenling foetus in stuitligging het risico op een gestoorde psychomotorische ontwikkeling door een geplande vaginale baring toegenomen is, en of dit effect beïnvloed wordt door het geboortegewicht. Op tweejarige leeftijd zijn alle niet-gerandomiseerde kinderen geboren in stuitligging tijdens deelname aan de Term Breech Trial gescreend op een gestoorde ontwikkeling met de leeftijd en ontwikkeling vragenlijst (Ages and Stages Questionnaire; ASQ). Deze ASQ is een door de ouders in te vullen kind-observatie systeem dat is gevalideerd ten opzichte van de Bayley Scales of Infant Development als een hulpmiddel om te screenen op gestoorde psychomotorische ontwikkeling. De ASQ bestaat uit vijf domeinen met elk zes vragen waarvoor punten kunnen worden verkregen. Een domein is afwijkend indien er minder punten worden behaald dan het van tevoren vastgestelde afkappunt. De ASQ is afwijkend bij één of meer afwijkende domeinen.

Een ASQ op tweejarige leeftijd werd verkregen van 183 uit 203 kinderen (90.1\%). Bij $28 \%$ van de kinderen waren één of meer ASQ domeinen afwijkend. Er was geen verschil in de kans op afwijkende ASQ domeinen tussen een geplande vaginale baring en een geplande keizersnede $(p=0.99)$. Er bleek echter wel sprake van een verband tussen manier van bevallen en geboortegewicht, met een significant hoger risico op vertraagde psychomotorische ontwikkeling bij kinderen van meer dan 3500 gram na een geplande vaginale baring.

Gebaseerd op de ASQ resultaten valt te concluderen dat een geplande vaginale baring voor een voldragen kind in stuitligging met een geboortegewicht boven de 3500 gram gepaard gaat met een verhoogde kans op een vertraagde psychomotorische ontwikkeling op tweejarige leeftijd.

In hoofdstuk 5 worden de resultaten beschreven van verschillende aspecten van maternale gezondheid in dezelfde prospectieve cohortstudie twee jaar na de voldragen stuitbevalling. Aan de moeders werd gevraagd om twee jaar na de bevalling vragenlijsten in te vullen over hun gezondheid in de afgelopen drie tot zes maanden. Uitkomsten van de geplande keizersnede groep werden vergeleken met die van de geplande vaginale baring groep, onafhankelijk van het feit dat een vaginale bevalling gerealiseerd was of dat een 'spoed' keizersnede was verricht.

De vragenlijst twee jaar na de bevalling werd door 183 vrouwen ingevuld. In maternale ervaringen betreffende borstvoeding, verzorgen van het kind en de relatie met haar partner werd tussen de twee groepen geen verschil gevonden. Ook werden geen verschillen in de diverse onderzochte aspecten van maternale gezondheid, in seksuele activiteit of fertiliteit gevonden.

Concluderend was de maternale gezondheid twee jaar na de voldragen stuitbevalling hetzelfde na een geplande keizersnede als na een geplande vaginale baring.

In hoofdstuk 6 worden de ervaringen van de moeders over de geboorte van hun kind beschreven twee jaar na een voldragen stuitbevalling. Het betreft weer de moeders uit hetzelfde prospectieve cohort als beschreven in hoofdstuk 3 en 5 . Twee jaar na de bevalling werd de moeders gevraagd een vragenlijst in te vullen over hun ervaringen betreffende de bevalling en hun kijk op de zorg die hen was geboden tijdens de bevalling. Uitkomsten van de geplande keizersnede groep werden vergeleken met de geplande 
vaginale baring groep, onafhankelijk van het feit dat een vaginale bevalling gerealiseerd was of dat een 'spoed' keizersnede was verricht.

Significant meer vrouwen in de geplande keizersnede groep waren gerust over de gezondheid van hun kind tijdens de bevalling $(67.4 \%$ vs. $37.9 \%, \mathrm{p}=0.0006)$, terwijl meer vrouwen in de geplande vaginale baring groep zich herinnerden toen ongerust te zijn geweest over de gezondheid van hun kind $(45.0 \%$ vs. $25.6 \%, p=0.02)$. Verder ervoeren significant meer vrouwen in de geplande vaginale baring groep meer pijn tijdens de bevalling dan verwacht $(46.9 \%$ vs. $18.5 \%, p=0.008)$. In de geplande vaginale baring groep gaven significant minder vrouwen aan dat ze een actieve rol hadden gehad in het beslissingsproces $(59.1 \%$ vs. $85.3 \%, p=0.001)$.

Samenvattend bleek dat twee jaar na de bevalling meer vrouwen in de geplande vaginale baring groep zich herinnerden ongerust te zijn geweest over de gezondheid van hun kind tijdens de bevalling, meer pijn hadden gehad dan verwacht en minder betrokken waren geweest bij de besluitvorming over de wijze van bevallen.

In hoofdstuk 7 worden de neonatale mortaliteit en morbiditeit tussen voldragen kinderen in stuitligging en hoofdligging vergeleken in de periode voorafgaand aan de publicatie van de Term Breech Trial. In deze periode werd in Nederland over het algemeen geen keizersnede gepland en verricht, enkel vanwege de stuitligging van het kind. Alle kinderen in stuitligging werden vergeleken met twee kinderen in hoofdligging. In totaal werden 1119 bevallingen geïncludeerd. In beide groepen trad geen neonatale mortaliteit op. Ook werden geen verschillen gezien in ernstige of matige neonatale morbiditeit tussen beide groepen. Ondanks het geringe aantal bevallingen laat deze studie zien dat met een afwachtende benadering dezelfde neonatale resultaten bij geselecteerde kinderen in stuitligging kunnen worden behaald als bij kinderen in hoofdligging.

In hoofdstuk 8 wordt, met behulp van een klinisch voorbeeld, het proces van voorlichting bij een zwangere vrouw met een bijna voldragen kind in stuitligging beschreven. Zorgvuldig voorlichten over de manier van bevallen van een kind in stuitligging is moeilijk en kost veel tijd. De voorlichting moet objectief zijn en zonder vooroordelen. Een schema kan behulpzaam zijn om aan de zwangere de neonatale en maternale risico's uit te leggen. Als een vrouw slechts één kind wil lijkt een electieve keizersnede de beste optie. Een uitwendige versie om het kind te trachten te draaien behoort aan alle zwangeren met een voldragen kind in stuitligging te worden aangeboden, behoudens in het geval van een contra-indicatie. Voor een geplande vaginale baring zijn zowel een gemotiveerde moeder als een gemotiveerde dokter noodzakelijk. Wel moet duidelijk zijn dat als iemand kiest voor een geplande vaginale baring de kans op een 'spoed' keizersnede ongeveer $50 \%$ bedraagt. 
Hoofdstuk 9 geeft een korte beschouwing en aanbevelingen voor verder onderzoek.

Alle voor- en nadelen beschouwend lijkt voor een zwangere die slechts één kind wil een geplande keizersnede de beste optie, indien een uitwendige versie om te trachten het kind te draaien niet is gelukt.

Follow-up van de gevolgen van de toename van het aantal keizersneden is beslist noodzakelijk. Omdat in Nederland op dit moment, wegens privacyredenen, opeenvolgende bevallingen niet kunnen worden gekoppeld wordt de ontwikkeling van een uniek bevallingsnummer geadviseerd. 
Dankwoord 
Het grootste deel van dit proefschrift kwam tot stand door onderzoek met gegevens van voldagen kinderen gehoren in stuitligging en gegevens van hun moeders. Ik dank alle ouders die de vragenlijsten hebben teruggestuurd. Dit proefschrift was zonder hun inspaningen niet mogelijk geweest.

Prof. dr. I. (s. Nihhuis, beste Jan tha de nodige scepsis over de haalbaarheid van dit proefohrift, hasgst waarschijnlijk gevoed door mijn eigen twijfel, werd jij steeds enthoumiater. De grote lijnen werden door jou in de gaten gehouden en je kwam met zeer wardevolle adviezen en ideeën waardoor er altijd vooruitgang in het project bleef zittenl. Bedankt dat je mijn promotor hebt willen zijn.

Dr. F.J.M.E. Ruumen, beste Frans, in 1999 begon ik als assistent in Heerlen. Na enige tiid rolde ik in het "stuiten onderzoek", oftewel het onderzoek voor de Term Breech Trial Het was jouw idee on de niet-gerandomiseerde stuiten prospectief te gaan vervolgen, maar ook jij had niet kunnen bevroeden dat hat zou resulteren in dit proefschrift. Ik knester warme herinneringen aan ons werkbezoek in Toronto. Ik dank je voor het me atan de hand nemen tijdens mijn eerste schreden op het wetenschappelijke pad, maar meer nog voor het feit dat jij er altijd in hebt geloofd.

Dr. L.J.M. Smits, beste Luc, ik kwam met een statistische vraag waarna jij me vertelde dat je geen statisticus bent, maar een epidemioloog. Echter de vraag werd opgelost en de andere vragen die volgden ook. De commentaren die je gaf op de manuscripten waren altijd zeer bescheiden geformuleerd, maar sneden altijd hout. Veel dank.

Beste Otto, paranimf. Alweer 6 jaar geleden was het andersom, jij de promovendus en ik de paranimf. Sinds die tijd is er alweer veel gebeurd en hebben we letterlijk en figuurlijk verschillende 'bergen' bedwongen. Ik ben blij dat je heden aan mijn zijde staat. Onze jaarlijkse fietstocht houden we wat mij betreft nog heel lang vol!

Lieve Kim. mijn andere paranimf. Ik ben blij dat jij, die in het dagelijks leven ook naast mij staat, vandaag mijn paranimf wilt zijn. De afgelopen jaren heb je mijn gemor, gesteun, gegrom en geklaag aangehoord. Dank je wel voor je positieve input en relativering. Vanaf vandaag ben ik de 's' kwijt, nu jij nog!

De leescommissie, bestaande uit Prof. dr. L.J.I. Zimmermann, Dr. S.E. Buitendijk, Prof. dr. G.H.A. Visser en Prof. dr. G.M.W.R. de Wert, wil ik danken voor de beoordeling van dit proefschrift.

De verschillende studenten: Santy Debie, Peggy Vencken, Lilian Sonnemans en Eef Reijners, dank ik voor al hun inspanningen. Al leek het er enige tijd niet op, allemaal hebben jullie er gelukkig minstens eén publicatie aan overgehouden.

De dames van de bibliotheek in het Atrium te lleerlen, in het bijzonder Miriam Wetzels, dank ik voor het opzoeken en opvragen van alle artikelen die ik in de loop der tijd wilde hebben. 
Mijn maten in Geldrop dank ik voor hun niet aflatende belangstelling en steun, Mariette in het bijzonder voor het kritisch doorlezen van het manuscript. Ik ben blij bij jullie terecht te zijn gekomen.

De maatschap gynaecologie te Heerlen, mijn eerste jaar als gynaecoloog heb ik in jullie midden als chef de clinique doorgebracht met een dag in de week voor onderzoek, dit heeft het treintje rijdende gehouden op een moment dat het stil had komen te staan. Dank hiervoor en voor jullie voortdurende belangstelling over de voortgang van het project.

Lieve mam, na het schrijven van het eerste artikel was ik in jouw ogen al bijna gepromoveerd. Het duurde echter nog een paar jaar, maar nu kun je echt tegen al je vriendinnen roepen dat jouw zoon gepromoveerd is.

Pap, als zoon wil je bepaalde dingen beter doen dan je vader. Ik denk dat ik nu wel mag zeggen dat ik je wetenschappelijk voorbij ben gestreefd. Ik zie uit naar de nu echt vrije maandagen, dan kunnen we fijn samen gaan golfen! Mam, pap, ik hou van jullie.

Lieve vrienden, nog niet genoemd. Een tropenperiode is afgesloten: na zeven jaar Limburg en het voltooien van een boekje wat vrije tijd tot een schaars goed maakte, breekt nu een tijd aan waar tijd weer een beschikbare factor lijkt en de afstand te bereizen. Ik hoop jullie allen weer vaker te zien. 
Curriculum Vitae 
Jan Frans Marie Molkenboer, geboren te Sittard op 5 mei 1971, behaalde in 1990 zijn VWO diploma aan het Sint-Odulphuslyceum in Tilburg, waarna hij in hetzelfde jaar geneeskunde ging studeren aan de Vrije Universiteit te Amsterdam. Na zijn artsexamen in juli 1998 vertrok hij voor een half jaar naar Zuid-Afrika voor een stage gynaecologische oncologie in het Groote Schuur Hospitaal (Kaapstad, Dr. R.P. Soeters). Na terugkomst werkte hij gedurende enkele maanden in het Twee Steden Ziekenhuis (Tilburg, Dr. H.C.L.V. Kock), om vervolgens in mei 1999 zijn opleiding tot gynaecoloog te starten in het Atrium Medisch Centrum Parkstad (Heerlen, opleiders: Dr. J. Stoot / Dr. F.J.M.E. Roumen). Het academische deel van de opleiding werd volbracht in het Academisch Ziekenhuis Maastricht (opleider: Prof. dr. J.L.H. Evers). Na zijn registratie als gynaecoloog op 1 mei 2005 werkte hij 1 jaar als chef de clinique in het Atrium Medisch Centrum Parkstad te Heerlen. Sedert 1 mei 2006 is hij gevestigd als gynaecoloog in het St. Anna ziekenhuis te Geldrop. 
List of publications 
Molkenboer JFM, Roumen FJME. Transvaginale echoscopie bij de genitale prolaps, een waardevolle aanvulling. NTOG 2002;115:270-4.

Molkenboer JFM, Bouckaert PXJM, Roumen FJME. Recent trends in breech delivery in the Netherlands. BJOG 2003;110:948-51.

Molkenboer JFM, Reijners EPJ, Nijhuis JG, Roumen FJME. Moderate neonatal morbidity after vaginal term breech delivery. J Matern Fetal Neonatal Med 2004;16:357-61.

Molkenboer JFM, Hermans RHM. Een vrouw met een vulvaire zwelling: een zeldzame uiting van het Klippel-Trenaunay-Weber syndroom. NTVG 2005;149:2287-9.

Molkenboer JFM, Vos AH, Schouten HC, Vos MC. Acute lymfoblastic leukemia in pregnancy. Neth J Med 2005;63:361-3.

Molkenboer JFM, Roumen FJME, Smits LJM, Nijhuis JG. Birth weight and neurodevelopmental outcome of children at 2 years of age after planned vaginal delivery for breech presentation at term. Am J Obstet Gynecol 2006;194:624-9.

Molkenboer JFM, Roumen FJME, Smits LJM, Nijhuis JG. Authors' response to comment of de Leeuw and Verhoeven. Am J Obstet Gynecol 2007;196:e15; author reply e16. Epub 2006 Oct 5.

Molkenboer JFM, Debie S, Roumen FJME, Smits LJM, Nijhuis JG. Maternal health outcomes two years after term breech delivery. J Matern Fetal Neonatal Med 2007;20:319-24.

Molkenboer JFM, Debie S, Roumen FJME, Smits LJM, Nijhuis JG. Mothers' views two years after term breech delivery. J Psychosom Obstet Gynaecol 2007; Jul 19:1-6 [Epub ahead of print].

Molkenboer JFM, Vencken PMLH, Sonnemans LGJ, Roumen FJME, Smits F, Buitendijk SE, Nijhuis JG. Conservative management in breech deliveries leads to similar results compared with cephalic deliveries. J Matern Fetal Neonatal Med 2007;20:599-603.

Roumen FJME, Molkenboer JFM. Stuitligging, gaat het debat verder? In: Slager E, editor. Reproductieve geneeskunde, gynaecologie en obstetrie anno 2007. Haarlem: DCHG medische uitgeverij; 2007. p 500-505. 